M. M. Yarosh

B. L. Nichols

E. A. Hirst

J. W. Michet

W. C. Yee

NOTICE

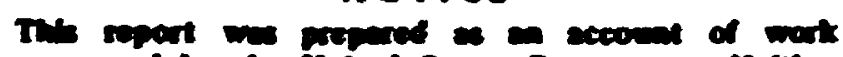

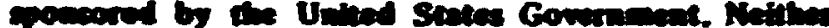

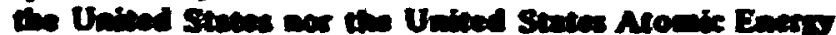

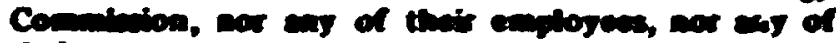

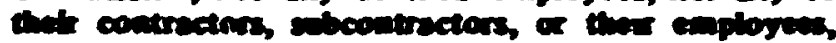

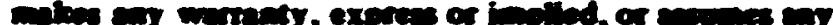

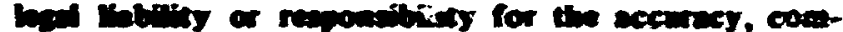

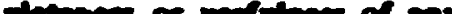

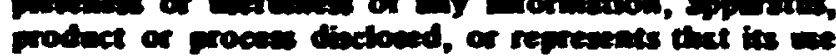

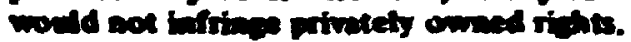

JULY 1972

OAK RIDGE NATIONAL LABOAATOAY Gak Aidge, Tennessee 37830 operated by UNION CARBIDE CORPORATION for the

U.S. ATOMIC ENF.RGY COMMISSION 


Printed in the United States of Amserica. Aveilable from
Nationat Technical Information Service
U.S. Department of Commerce
5285 Port Royal Roed, Springfield, Virginia 22151
Price: Printed Copy \$3.00; Microfiche $\$ 0.95$

This report wo prepered os in sccount of woik sponsored by the Urited Simes Government. Neiciver the United Stentes nor the United States Atomic Energy Cornmissir..., mee any of their employees, nor any of their contractors. subcontractor., or their employees, makes any merranty. express or implied, or scumes e.ov repl lisbility or responsibility for the securacy. completeness or usefulines of eny information, apperstus, product or process disclosed, or represints the its use mold not infrine privately owned rights. 


\section{CONTENTS}

PREFACE

SUMMARY vii

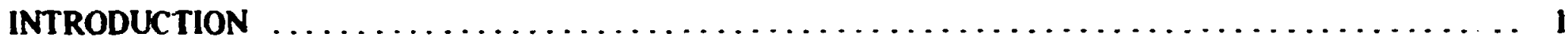

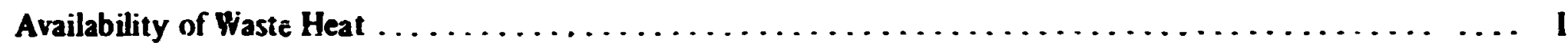

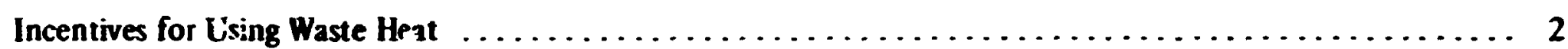

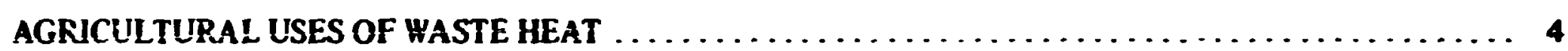

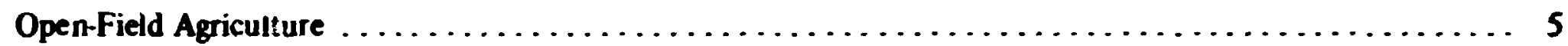

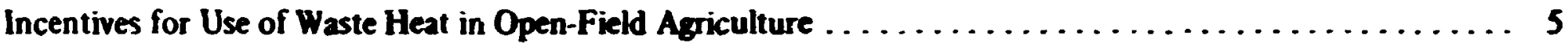

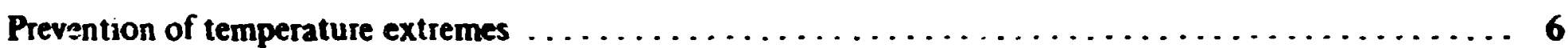

Expansion of the grow:

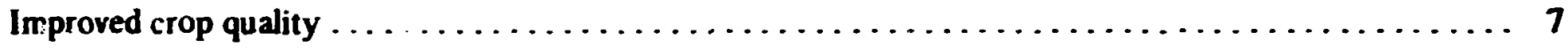

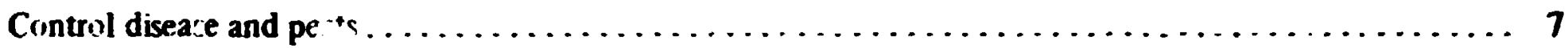

Current Research Programs ia Applications .............................. 7

Potential Problem Areas . . . . . . . . . . . . . . . . . . . . . . . . .

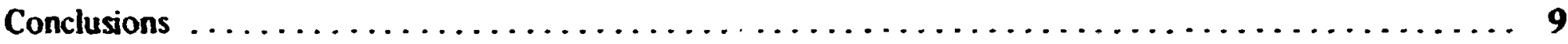

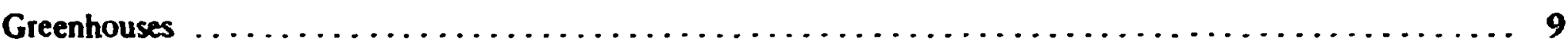

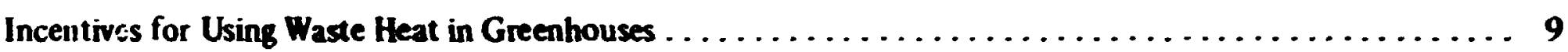

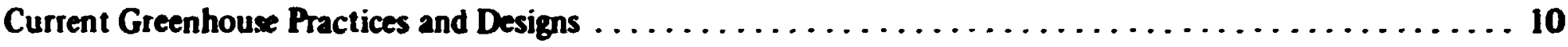

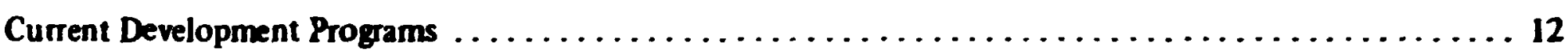

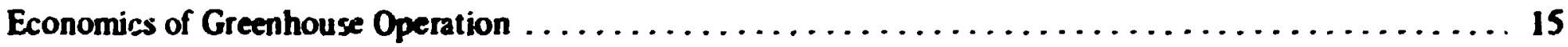

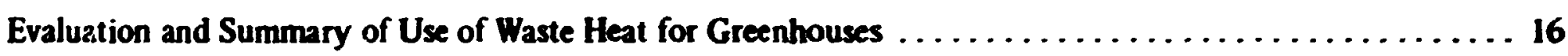

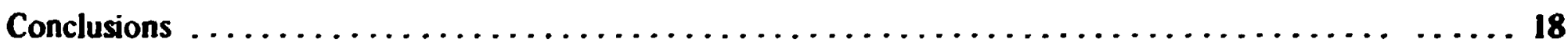

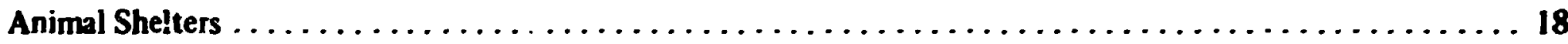

Poultry Operations . . . . . . . . . . . . . . . . . . . . 18

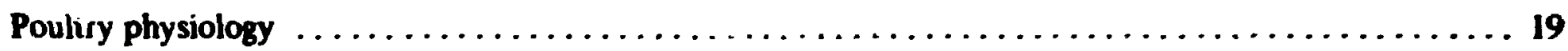

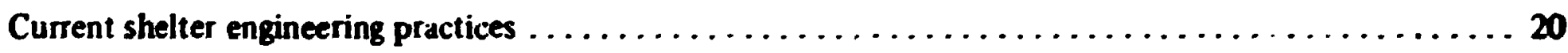

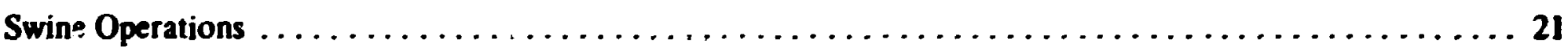

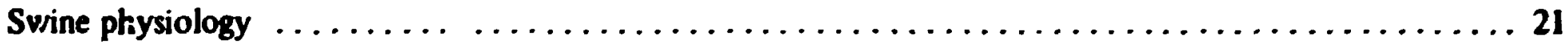

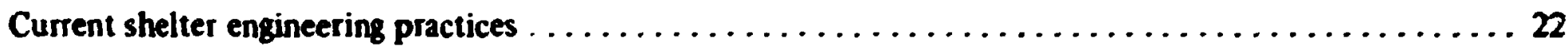

Potential Benefits of Waste Heat Utilization . . . . . . . . . . . . . . . . . . . . . 24

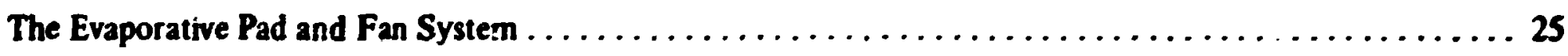

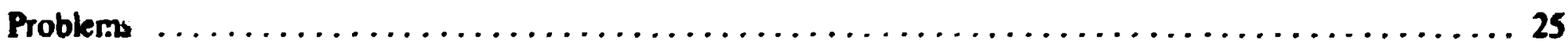

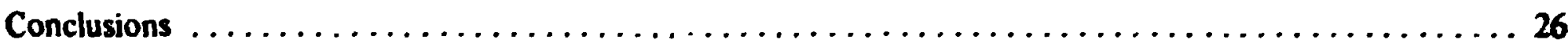

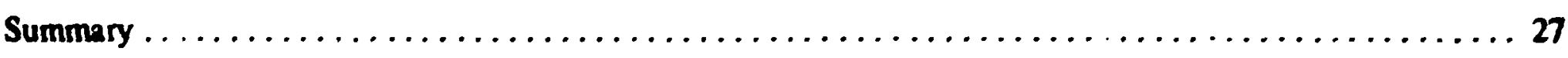

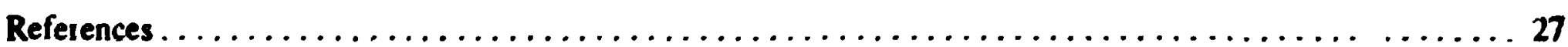




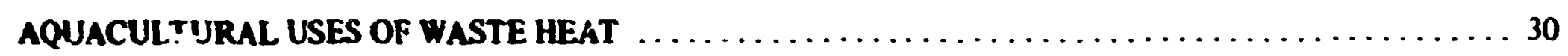

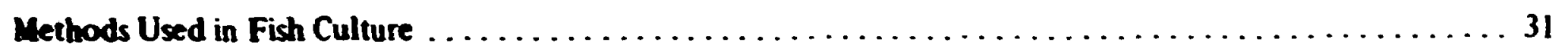

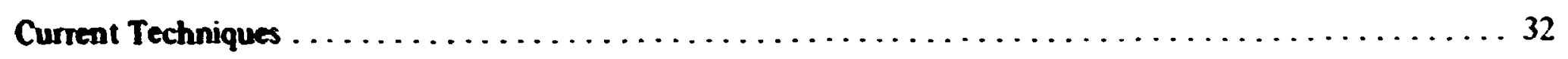

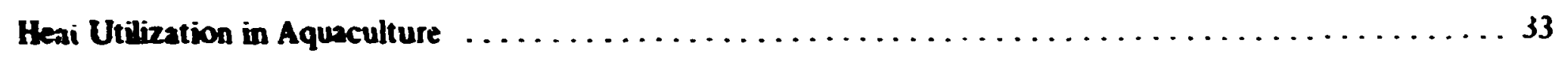

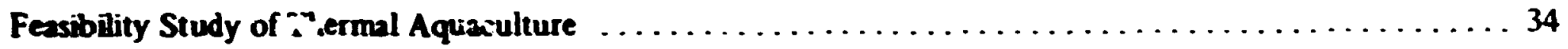

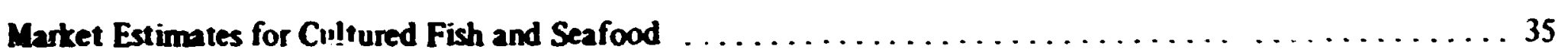

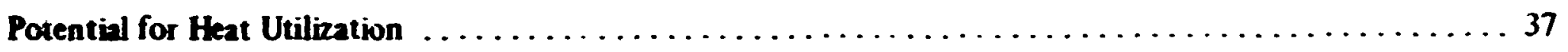

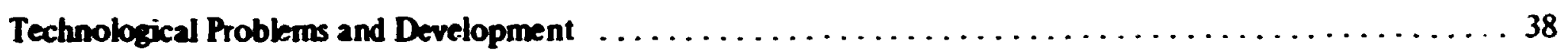

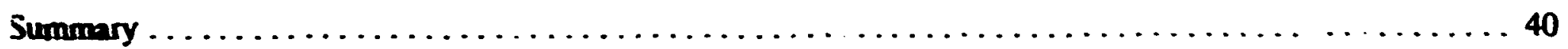

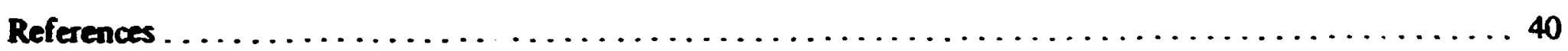

CONSIDERATIONS IN MPLEMENTING WASTE HEAT USE $\ldots \ldots \ldots \ldots \ldots \ldots \ldots \ldots \ldots \ldots \ldots$

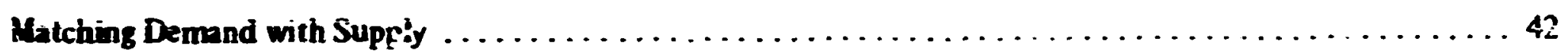

Considersions in the

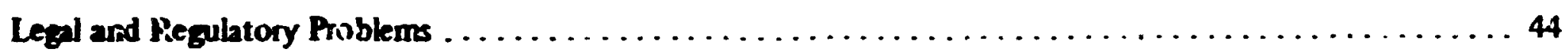

Site Selection and Environmental Considerations with Waste Heat Utilization $\ldots \ldots \ldots \ldots \ldots \ldots \ldots \ldots$

Keferences . . . . . . . . . . . . . . . . . . . . . . . . . . . . . . . . . . . . . . . . 46

This repori in productive uses of waste heat represents the results of an intensive effort over a limited time period to collect information on the subject topic. We recognized that within the time period allotted for this effort, it would not be possible to include all relevant information on heat utilization, but an effort was made to present information on the primary identifiable uses. The work benefited fiom the experience on the subject of a number of the contributing authors, and particularly from the many review comments of S. E. Beall of ORNL. This report is confined to discussions of waste heat uses only. In the report, we address principally the use of heat rejected from large central station electric generating plants. The coupling of heat utilization applications with smaller integrated utility sysirms is recognized as having significant potential advantages, but these systems are not extensively treated in this report. The section on Considera. tions in Implementing Waste Heat Use draws liberally from ideas, discussions, and information presented at The National Conference on Waste Heat Utilization held in Gatlinburg in October of 1971.

\footnotetext{
- Proceedings of the National Conference on Waste Heat Utilization, October 27-29, 1971, Gatlinburg, Tennessee, Report Number CONF-711031. (Available from Dept. of Commerce, National Technical Information Service, Springfield, Virginis 22151.)
} 


\section{SUMMARY}

Presint steari power plants in the United States dischirge as waste heat, energy equivalent to approximately twice their total present electrical generating capicity $(\sim 300,000 \mathrm{MW}(\mathrm{e}))$. Because this energy is des.raded in temperature it is difficult to use. It represents a necessary, but unwanted, by-product of the e:xergy conversion process for generating electricity.

Because of the growing quantities of waste heat discharged and the increasing national concern with energy growth, energy utilization and thermal discharge problems have stimulated an examination of methods for productively using energy presently wastec to the environment

The productive use of waste heat from steam elect:ic plants that substitutes for heat energy which would otherwise have to be generated, results in a net improvement in our efficiency of energy use, and in energy conservation. Using a steam electric plant to supply both heat and electricity improves energy utilization. It is important to note that improving energy utilization in this fashion may be as effective as improving electrical conversion efficiency.

All energy ultimately appears as low temperature heat; indeed, low temperature heat has been aptly called "the ultimate waste." It would be wrong to suggest that waste heat is "used" and that after use it disa ?pears from the environment. The term "utilization of waste heat" refers to the performance of useful functions with the heat before it is discharged to the environment. Even though all energy ultimately appears in the environment as heat, the energy may move from a highly concentrated point source to a widely dispersed geographic aria where it may be environmentally more acceptable.

There are relatirely few applications where serious consideration has been given to the use of reject heat from steam electric power plants. These include: the use of heat for food production in agriculture and aquaculture; the use of heat for urban and industrial applications; and the use in specialized processes. No one of these individual uses would be expected, by itself, to have a very significant effect on energy utilization and conservation at any single plant site. However, combinations of the various uses selected for a particular site could have a significant effect at that site.

\section{Agriculture}

Agricultural operations can use waste heat from power plants withou: . . ;.scing electrical energy produc- tion. While these uses will not sobe the problems of thermal discharge, they may, in particular locations. reduce the impact of thermal effuents on the local ecology, corserve energy resources, and be profitable to both the electric utility and the farmer.

Thermal effuents from yower plants potentially can be used in open-freld agrizulture to promote rapid plant growth, improve crop quality, extend the growing season, and prevent damage due to temperature extremes. Wate, uied for both irrigaion and heating, can be applied through nozales (spray irrization) or ilfough subsurface porous pipes. With these systems the farm acts as a large, direct-contact heat exchanger for the power plant, while the utility provides imigation, water to tive farmer.

This heat is important for only a small portion of the year (early spring and late fail). During the remainder of the year, water is needed for irrigation, but not for heatisg. However, most power plants are sited near urban centers and most urban centers are in areas where rainfall is sufficient to obviate the need for irriontion. The longterm implications of waste heat applications for soil management, disease and pest control are not yet known. Thus the justification for the capital costs required for open-field agriculture requires careful study at each site.

The use of power plant waste heat for waming and cooling greenhouses can improve crop growth and yield and reduce operating (fuel) costs by 23 much as

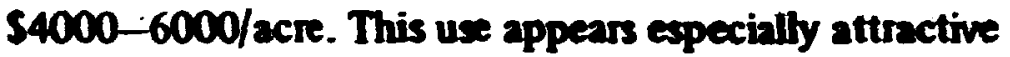
for large growers tu locate near power stations. Greenhouses may eliminate or reduce the need for cooling towers in certain instances.

Research at the University of Arizon, University oi Sonora, and the Oak Ridge National Laboratory angests that using waste heat for greenhouse chimate control is both feasible and economically attretive. However, no large-scale field demonstrations or operations are curret: ily underway in this country.

Waste heat also could be used to provide optimal temperature control in swine and broiler houses. In addition to reductions in heat costs, seving in feed costs should result from improved feed efficiency under contiolled environmental conditions. To iate, no detailed studies have been performed to determine the technical and economic feasibility of auch systems.

The fraction of the total waste heat produced in the U.S. that might reasonably be used in agriculture is quite low, probably less than 10\%. Additional study is required to determine the limitations imposed by 
climate, geography, product marketing, waste heat reliability, animal waste disposal, effects of biocides and corrosion inhibitors in the cooling water, and consumer acceptance of products grown using cooling water from nuciear plants. These problem areas should be thoroughly investigated before a commitunent is made to largi-scale agricultural applications of waste heat. In some "local" situai ions, agricultural applications seem io offer significant economic value.

\section{Aquaculture}

The use of heated discharge water to improve the yields and productivity for fish and seafood species is receiving attention in this country and abroad. Basic hata indicate that catfish grow three times faster at $83^{\circ} \mathrm{F}$ !har: at $76^{\circ} \mathrm{F}$. Similarly shrimp growth is increased by about $80 \%$ when water is maintained at $80^{\circ} \mathrm{F}$ instead of $70^{\circ} \mathrm{F}$. Though few experiments in thermal aquaculture (the culturing of aquatic species using heated water to achieve near of timum water temperatures) have been carried out, studies indicate that maximum yield may be achieved in facilities employing flowing water channels where control is exercised over water temperatures. Control of dissolved oxygen and the buildup of wastes, as well as controlled feeding of a nutritionally balanced food will be essential to achieve maximum yikelds. The few operations conducted in this country and abroad have produced equivalent annual fish yields above 100 tons/acrs.

The cse of heated discharge water for aquaculture will have eseentially no impact on the total quantity of heat discharged at the power plant. The discharge temperature, however, may be reduced somewhat by blending ambient water with the heated discharge water during the sumumer to prevent over-heating the culture facility. Unless fish wastes are removed, particularly in channel culture, water quality leaving the facility may be degraded in oxygen content because biological oxygen demand is increased and this in tum may degrade water quality in the receiving water body. Ameliorating thesc problems is technically difficult and costs for doing so have not been studied.

The development of extensive thermal aquacultural feclities appears to have the potential for revolutionizin the production of fish and seafood in much the same manner as has been done in the poultry industry. The economic potential appears attractive. As with agriculture, however, the fraction of the total waste heat from power plants which is used may be small. This fraction would be sensitive to the growth in consumption of seafood in this country, and localized applications may be the first to evolve. Aquaculture may offer an answer to the major problem foreseen by the seafood industry - a scarcity of supply from matural sources.

Studies, to date, have presumed direct cooling systems where discharge water from the plant would be used for agriculture or aquaculture en route to the receiving water body, but systems operating with cooling towers might also be feasible. Operating water temperatures with cooling towers are higher and this may increase the flexibility of operations. Water quality considerations, however, in closed cycle cooling tower systems will require careful attention in the design of such applications.

\section{Implementation}

The application of existing technology to the large siale use of waste heat requires the consideration of many problems of implementation.

Most moderri steam power plants discharge much more waste heat than may cunveniently or economically be used at one location, thereby presenting problems of matching the supply of waste heat with the demand. The investment in facilities at a single site to use all the waste heat produced would be very large, while the use of only a fraction of the waste heat produced may preclude an effective substitution for the cooling methods originally proposed. Soluitions to problems such as these must be achieved before. widespread ur of waste heat is possible.

Utilities are concerned about how expenditures on research and development for using waste heat will be treated by rate regulating agencies. Questions arise on whether utilities marketing heat at profit will have to credit the profits against electrical production costs and therefore be penalized on their permissible electrical rates. The position taken by regulatory agencies will be strongly influenced by the specific arrangements hetween the utility and the waste heat entrepreneur. The position taken by the regulatory agencies will affect the decisions of the utility on marketing of waste heat. Side benefits accrued by the utility, such as a reduction in heat dissipation equipment costs, may encourage the utility to offer heat at very low cost.

The tsend toward increasingly restrictive water qual ity standards may affect the development of certain uses of waste heat. Imposing very low temperature rise limits in receiving water bodies, for example, may pose serious problems to developing a viable aquaculture operation. In some heat use applications, such as open-field agriculture, vrater is consumed and in mosr. 
states water laws restrict the permissible quantities of water that can be removed but not returned to the water bodies. These restrictions may preclude certain uses of waste heat.

The waste problems created by the use of heat for agriculture and aquaculture must be examined and defined in sufficient detail so that the environmental effects do not negate the advantages gained by combining the application of heat use with power production. Problems ascociated with animal waste from areas of high density animal production (cattle and poultry, for example) are well recognized. Little information exists on the waste problem from aquaculture facilities, but this topic should be carefully considered.
Heat applications should be considered in the power plant site selection process. This may facilitate the use of waste heat and can effect the water use rights established for the power plant facility.

The real and imagined problems associated with the use of heat from a nuclear power plant cannot be ignored. Food produced in or very near the exclusion area of a nuclear plant may be held suspect by the public. The degree of public acceptance must be determined. Even heat supplied from a nuclear power plant to an urban area may suffer from public skepticism. These and other probiems need to be addressed before widespread use of waste heat will become a reality. 


\title{
AGRICULTURAL AND AQUACULTURAL USES OF WASTE HEAT
}

\author{
M. M. Yarosh \\ E. A. Hirst \\ J. W. Michel \\ B. L. Nichols \\ W. C. Yee
}

\section{INTRODUCTION}

Few will dispute the importance of abundant energy in our national development. Through its massive energy capacity, the United States, with 200 million people, marshals the equivalent manpower effort of 100 billion individuals. Abundant energy has enabled the production of goods and materials and the establishment of a standard of living which would otherwise be unattainable. Through inescapable byproducts, however, the rapic Fowth of energy has had increasing impact on our society in ways that were previously unforeseen. One of these byproducts is low-temperature energy in the form of heat. Wa sometimes find this heat difficult to discard, and because of its low temperature, always difficult to use.

The principal energy consumption sectors in this country include transportation, industry, residential and conmercial uses, and the generation of electricity. Of these, the last is the fastest growing constrmer. While our population doubles approximately every 50 years, our consumption of electrical energy doubles approximately every 10 years.

A basic principle of nature (enunciated as the second law of thermodynamics) is that ultimately all energy (mechanical, electrical, nuckear, chemical, etc.), when converted, appears as heat. For example, a nuclear power plant operating at 33\% efficiency requires 3 $k$ Whr of muclear energy to produce $1 \mathrm{kWh}$ of electrical energy. The remaining $2 \mathrm{kWhr}$ appear as themal energy in the condenser cooling water and are discharged to the environment. Ultimately, however, the $1 \mathrm{kWhr}$ of electricity abo is degraded to heat. The energy supplied by the electricity may be used to operate air conditioners, water heaters, television sets, washing machines, for industrial and other applications, and then appear as heat at these individual sites. Thus, even though the power plant is capable of converting nuclear and fossil fuel energy into electrical energy, eventualiy all the energy appears as heat.

\section{Avalibility of Waste lleat}

In modern plants electricity is generated with efficiencies ranging from about 33 to $40 \%$, depending principally on the age and type of the power plant. The water-cooled nuclear plants presently being built have efficiencies of about 33\%, while modern fosilifueled plants are near $\mathbf{4 0 \%}$ efficient. Projections for advanced gas-sioled reactors and breeder reactors show effciencies of near $40 \%$. Significant quantities of waste heat are also available from smaller energy sources such as those employed for industrial applications or small system applications as in shopping centers. Indeed the smaller system sources provide a means of achieving a better match between available heat and potential uses. Unfortunately, efficiency has been increasing only very slowly over the past two decades, so the waste heat produced has been increasing almost linearly with the growth in electrical generation; this is shown in terms of heat rate and efficiency in Fig. 1.

Compared with other energy conversion processes, the generation of electricity is efficient. The internal combustion engine, for example, converts chemical fuel to mechanical energy with an efficiency of about 15\%. Electrical generation, however, is carried out in large plants, and thus large point sources of waste heat are produced that must be dissipared at or near the point of electrical generation.

Ovei the past two decades, the capacity of electrical power plants has increased significantly, as snown in Fig. 2. In 1950 the size of the average urit placed in operation in the U.S. was cnly $48 \mathrm{MW}(\mathrm{e})$, but by 1970 the size of the average nuclear plant scheduled fo: operation was over $700 \mathrm{MW}(\mathrm{e})$. Also the construction of multiple units at a given site has further incridsed the difficult task of handling the large, but local, sources of waste heat. In i970 the electrical generating capacity of steam-electric plants in the United States was approximately $265,000 \mathrm{MW}$. These plants annually produce about $5 \times 10^{15}$ Btu of waste heat.

The generation of large quantities of waste heat at point sources requires the development of techniques for safe disposition of this heat. The traditional method of handling it has been to discharge it to a nearby natural or artificial body of water. When adequate cooling water is not availabie, evaporative cooling towers are used for discharging the heat to the atmosphere. Because of the increased size of power plants and the consequent increased waste heat load, adequate cooling water supplies for heat dissipation are becoming difficult to find. Commonly for direct water cooling, between 1.2 and $1.8 \mathrm{cfs}$ of water is required per megawatt of electrical power generation. The amount is dependent on plant efficiency and condenser water temperature rise. Power plant sites of more than $3000 \mathrm{MW}$ of capacity are becoming more common. Thus for large plant sites several thousand cubic feet per 


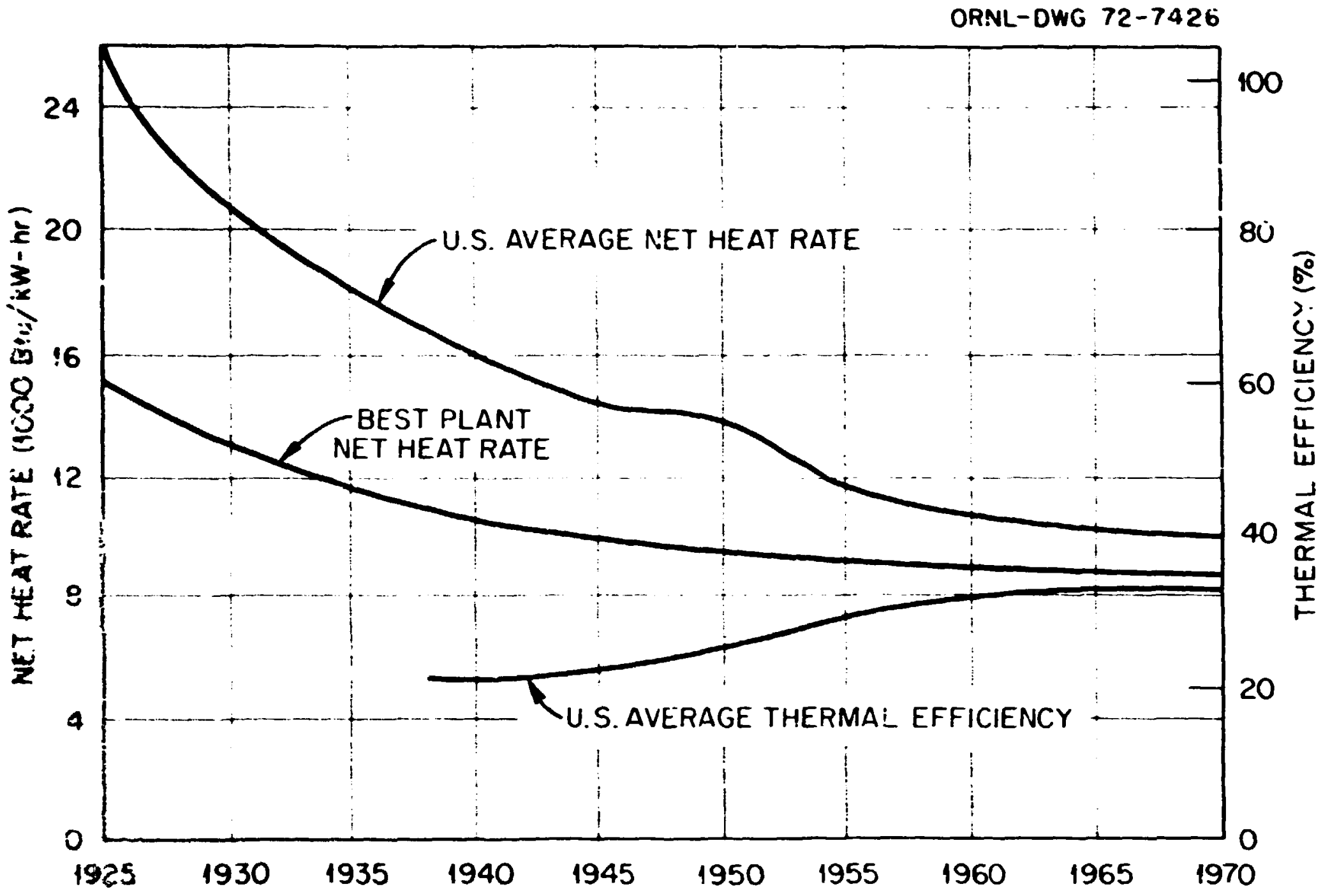

F. 1. Heat rate and thermal efficiency of steam gerrerating phants.

second of water elevated perhaps $20^{\circ} \mathrm{F}$ in temperature above normal ambient is discharged from the power phant.

Ping: thermal eificiency is ofien expressed in terms of the plant "heat rate," which is the number of BTU's of energy requared to produce a kilowatt hour of electricixy. As efficiency oreases, the plant heat rate deitreases.

\section{Incentives for Uing wate Heat}

The discharge of large quantities of heat to a body of werter may alicr the temperature of the receiving water afficiently to ravis unacceptable changes in the aquatic biota. As a result, increasingly stringent standreds on arceptable temperature alterations to such water bedits are teing imposed by state and federal requbtions.

Disposition of the heat to the atmosphere through coving towers may produce undesirable meteorological effectr. Cooting twrers also impose extra equipment costs on the plant operator and reduce p'ant cycle efficiency. Utimately, of course, all net heat loss is transferred through the atmosphere to the ultimate heat sink - space.

These factors have increased interest in methods for utilizing the rejected heat from power plants. The utilization of waste heat might, in some cases, afford the opportunity tu reduce the adverse environmental impact of waste heat discharge, reduce the cost of handling thermal discharges, and will improve overall energy utilization.

It is imporrant to define waste heat and distinguish it from low-temperature heat. "Waste" heat designates energy which is so degraded in temperature that its uses are limited, and usually it is considered practical only to discharge it directly to the environment. Typically, such energy appears in the large quantities of cooling water used for condensing the stears. discharged at the turbine in stealırelectric power plants. Typical outlet temperatures for such cooling water are in the range 60 to $95^{\circ} \mathrm{F}$, depending on the ambient water temperature, the quantity of water circulated, and other factors. For hose power plants that have evaporative cooling towers the outlet water temperature would be increased by 15 or $20^{\circ} \mathrm{F}$ (i.e., to the 75 to $115^{\circ} \mathrm{F}$ range), while for dry 
cooling towers it would be increased by 20 to $40^{\circ} \mathrm{F}$ (80 to $135^{\circ} \mathrm{F}$ range).

"Low temperature" designates heat that has not been degraded to waste heat temperature levels. For exaniple, the extraction of steam from a turbine before it has reached waste heat levels permits utilization of the heat extracted for functions requiring higher than waste heat temperatures. Typically, low-temperature heat is in the temperature range ! 00 to $400^{\circ} \mathrm{F}$. Utilization of this heat from the turbine permits better utilization of the energy remaining in the steam, but it also reduces the efficiency of the turbine cycle. Low-temperature heat s.tay be typically used in space heating and cooling for urban applications. The use of this heat will not be discussed in this report.

Waste heat, as discussed in this report, can be used for heating greenhouses and animal shelters, for providing frost protection in open-field agriculture, or to maintain optimum temperature for the culture of aquatic organisms such as sintrimp or fish in aquaculture.

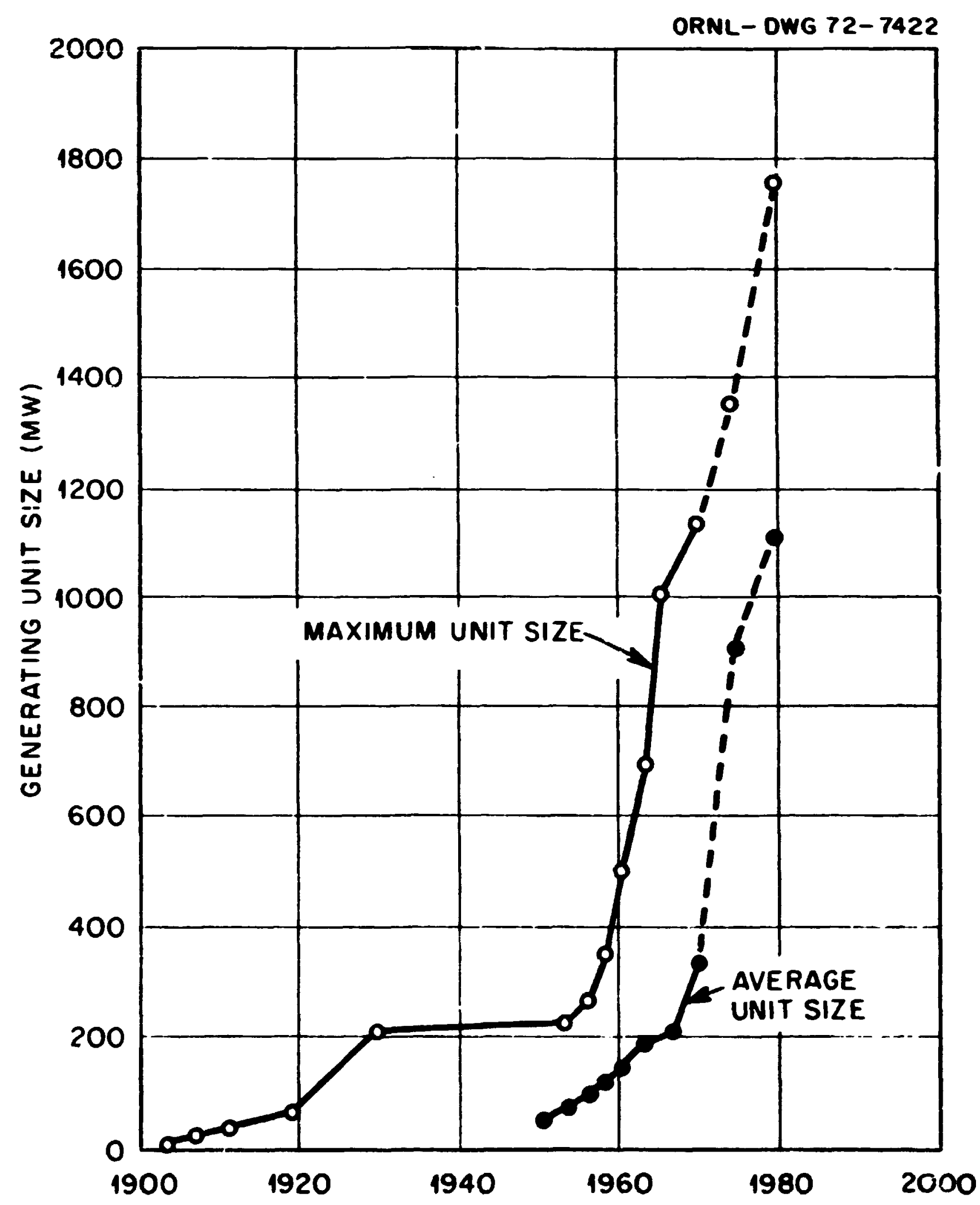

Fif 2. Steam generating plant unit size. 
At present, the waste heat from power plants represents an unpurchased product. If this heat could be marketed, the power plant owner could realize an additional retum from his operation. In view of more restrictive regulations on the discharge of heat to the environment, this might provide the best opportunity for both a ieduction in impact and in cost to the power prüucer.

The user of heat might benefit from the opportunity to purchase heat at a lower cost than is otherwise possible. In cases such as the hoating of greenhouses, heating costs range from $\$ 4000: 0 \$ 12,000$ per acre per year, depending on the crop and the locstion. Energy costs of fuel vary frum $40 \$$ to $\$ 1.50$ per million Btu, and the lowei energy costs possible from the use of waste heat could provide for considerable savings. Comparable savings might be possible for other uses. Total integrated waste heat utilization designs for power plants would allow use of the heated effluent during the entire year. Even if heat were sold only during the winter, however, the savings to the power producer could reduce the "add on" costs which result from requirements to provide treatment of the heated effluent coming from the power plant.

This report is irtended to provide a survey of some of the possible uses for waste heat from steam-electric plants. The state of technology for use of this heat and the primary applications are discussed. This report also attempts to answer the more likely questions on waste heat use and provides references to additional information.

The methois described in this report caniot reduce the total thermal energy dissipated from power plants per unit of electricity gerierated. However, these processes can provide ways in which this heat can be substituted for the heat consumption of other energy sources. In this way energy and fuels can be conserved and thermal discharges redused on a national and global scale. These processes may also permit the introduction of heat into the environment in a more acceptable manner and reduce other environmental insults. Though individual uses may be small, integrated waste heat use for several purposes could provide for better use of energy and increase the total use of the site.

It should be recognized that no single solution exists to the problems of waste heat discharge or to the increasing difficulties in finding sites for steam-electric power plants. However, under some circumstances these problems may be partially alleviated by methods employing heat utilization. No single method for heat use may, by itself, represent a significant outlet for waste heat. The total energy use (hence, energy savings), however, for a variety or heat applications can be significant. If it were possible to use only $10 \%$ of the heat rejected from the generating stations to be built over the next $\mathbf{3 0}$ years, the net effect would be to use more rejecteo energy than the equivalent in electrical energy generated today $[\sim 300,000 \mathrm{MW}(e)]$. On the other hand, it must be recognized that the economic utilization of large quantities of energy at low temperature is a difficult task, which otherwise would have already been solved. The incentives for solutions to waste heat utilization have increased, however, and seem likely to continue to increase in the future.

The opportunities that exist for utilizing waste heat are just beginning to be explored in this sountry. Because it is important to recognize the role that heat utilization may play in the generatiun of electrical energy, this report summarizes the methods available and the status of their application.

The use of low temperature heat from electrical generating centers is not discussed in this report. Nonetheless, such use also permits the application of heat energy in a manner which improves overall energy utilization and contributes to energy conservation. This energy conservation should become a national goal - so many people think.

\section{AGRICULTURAL USES OF WASTE HEAT}

In contrast to many urban and industrial heat applications which require heat at temperatures higner than is normally wasted from electric generating or other steam process plants, several agricultural uses (e.g., spray irrigation, soil heating, and environmental control of animal shelters and greenhouses) offer a way to use the thermal discharges without reducing electrical energy production. (For example, steam or hot water at $300^{\circ} \mathrm{F}$ is needed for the various urban energy requirements currently under consideration. If steam from back-pressure turbines is extracted at $300^{\circ} \mathrm{F}$ rather than at $100^{\circ} \mathrm{F}$, the gross turbine cycle efficiency is decreased from $47 \%$ to $30 \%$ for a modern fossilfueled plant, and from $33 \%$ to $18 \%$ for a light-water reactor nuclear plant.') Power plants with cooling towers are normally designed so that the temperature of condenser effluent is between 80 and $120^{\circ} \mathrm{F}$; $p^{\prime}$ ants with once-through cocling operate near these temperatures much of the year but may discharge water as low as 55 or $60^{\circ} \mathrm{F}$ in the winter. In many locations these temperatures are high enough to provide satisfactory thermal environments for many plants and animals. Thus, agricultural operations which can be located close to the power station may truly be considered potential waste heat users 
Spray irrigation ard soil heating can be used to lengthen the growing season and provide frost pro tection in certain regions. Maintaining animal stelters at the proper temperatures can increase growth ates and feed efficiencies: this is particularly important for the smaller animals, such as poultry and swine. Greenhouse production of both flowers and vegetables is critically dependent on artificial heating and cooling, and the use of waste heat from condenser cooling water can significantly reduce fuel costs to greenhouse operators.

In spite of these obvious benefits from the use of waste heat for agricultural applications. severai potential obstacles exist. Most important, the current level of agricultural production is such that only a small fraction of the waste heat discharged from power plants can be used profitably, and the projec'ed gruwth patterns suggest that this picture will noi impic ve in the future. In addition, the rse of waste heat is strongly dependent on geography, slimate, and season. The size of the greenhouse, poultry, or swine operation required to use a reasonable fraction of the waste heat generated by a typical power plant is an order of magnitude larger than any installations in the U.S. today. However, several ioreign countries do have greenhouse operations that could use all the exhaust heat from a several hundred magawatt electric plant. Future greenhouse operations in the U.S. may be able to use the waste heat from power plants to replace the dependence on gas and other fuels which are in short supply. Such large operations, however, ray introduce new problems in management, disease 'ontrol, and waste disposal. Also for some operations, temperature control is not a con:rolling cost, and the lure of cheap (or even free) heat may not be sifficient to attract agricultural operations to power piant sites. ïirally, certain problems may arise in coupling the power plant operation and the agricultural operation. The utility may be reluctant to have a second party on its cooling system or to obligate itself to supply the warn water from a nuclear plant where concern on the liability for radioactive contamination may be a problem.

Nevertheless, agricultural uses of waste heat are sufficiently attractive, under certain conditions. to warrant serious consideration. While these uses will not solve the "therr.al poilution" problem, they an, in particular locations, reduce the impact of thermal effluents on the local ecology, conserve energy resources (reducing demand for fossil fuel heat), and save money for both 'he electric utility and the agricultural operator. The potential and problems associated with the use of waste heat for open-field agriculture, greenhnuses, and animal sheiters are discussed in the following sections of this chapter.

\section{Open-Fich Agriculdere}

Throughout the history of agriculture, $\operatorname{man}$ has generally been at the mercy of nature and has adapted to or accepted the vagaries of the weather or climate in his particular area. Control of iemperature in agricultural activities was initiated only recently and is still limited primarily to greenhouse horticulture and pout try operations. The importance of environmental control has long been recognized and studied, but the hiph cost of heat and equipment has limited its application to a few high-income crops.

Considerable study has been devoted to the effects of irrigation water (and soil) temperature on crop production and, of course, to the technical aspects of design and operating tecilniques intended to minimize the temperature changes. ${ }^{2}$ It is, however, important to recognize that much additional work is required as evidenced by the fol" swing statement, "Knowledge of how root temperature affects plant growth is woefully incomplete, partly because critical experiments are few and partly because of ignorance about root function. ${ }^{\text {m }}$

The idea of using waste heat from power stations for agricultural purposes was suggested at least as early as 1957,4 but it i: only recently that several investigators have begur. to study and evaluate the potential benefits, costs, and problems. As a consequence, little information in the literature is specifically directed toward the productive use of wiste heat in field agriculture. Nevertheless the use of warm water for field irrigation through subsoil or sprinkler application techniques represents potentral applications for the waste heat in discharge water.

\section{Incentives for Use of Waste Heat in Open-Field Agriculture}

Both plants and animals respond to specific environmental conditions that are conducive to optimum growth. Although these conditions vary considerably among species and at different growth stages, it is seldom that optimum values are maintaine 3 in nature. One of the important variables influencing plant growth is the temperature of both soil and air, and although this discussion deals primarily with temperature, it should be recognized that many other critical environmental factors interact with temperature and may require simultaneous adjustment as the temperature approa: hes an optimum level. These factors include soi moisture, air humidity, plant nutrition, and soil-air and atmc; pheric-air composition. It is known that within certain temperature ranges, biologic activity essentially doubles with each semperature increase of $10^{\circ} \mathrm{C}$, but 
thit too low or tow hich temperatures are lethal to plants. 5

Potential benefits of temperature control to openfield agriculture inchude the following:

1. prevention of damage caused by temperaiure exiremes,

2. extension of the growing season,

3. promotion of growth,

4. improsement of crop quality,

5. control of some diseases and pests.

Prevention of tempernture extremes. Perhaps the most obvious and the most easily adapted use of waste beat in the form of warm water is in frost protection, particularly to tree crops. Frost protection by sprinkler application depends on the "heat of fusion," that is, the release of heat by water as it freezes. A critical factor in this technique is the proper manasement of water application to preclude limb or stalk breakase fro.a ice formation, which can cause losses that exceed the loses cansed by frost. The use of warm water in the spray system can alleviate this problem.

Warm water can also be used to cool plants during the bot, dry summer months when atmospheric bumidities are low. In such a situation it has been demonstrated that warm water applied through a sprinkler system attains ambient temperature by the time it reaches the soil surface." Heat low results from evaporativn, cont in both the plants and the water supplied through the sprintlex.

The use of warm water for the purpose of controlling copp inmage due to extreme temperatures, while of vital agricultural importance, generally is required only a fen hours during a few days of a year. Thus, this application requires a highly reliable heat source which is used at a very low load factor, and would present problems in capital cost amortization, unless the wam wher can be distributed through an irrigtion system which would bave been needed inyway.

Expmise of the gowing seasos and promotion of perth Temperature is one of the most important fectors coverning the eermination of seeds. Cermina. tion, emergence, and earty growth of plants are int;mately reiated to soil temperature. The effects of weather are probably more critical during germination and early seedling development than during any other stage of vepetation growth. Unfarorable soil temperatures at seeding time often produce a poor stand and consequently a reduced yield. Retarded growth of youns seedlings may not only further reduce yield but also adversely affect the quality of the crop produced.?
Favorable temperatures at the seedling growth stage may :nhance growth sufficiently to provide the possibility for producing two or more crops per year, and thus geatly increase farm income. Also, achieving earlier crop maturity can give a large marketing advantage, particularly for high-value crops.

As indicated above, basic knowledge of the relationship of scil temperature to nlant growth is limited. Some literature is available on this subject, although much of it is related to plant growth in the noneconomic sense, that is, rate of net photosynthesis, total dry matter accumulation, time of (or percent) seed emergence, root vohme, etc. There is, however, some literature that discusses yields. In ont experiment, rice (grain) yields were increased from $32 \%$ to $55 \%$ by increasing the root temperature from $18^{\circ} \mathrm{C}$ in $30^{\circ} \mathrm{C}$. Com yields (silage) increased by $68 \%$ when the soil temperature was increased from $12^{\circ} \mathrm{C}$ to $27^{\circ} \mathrm{C}$, while for potatos (tubers) thrie yield increased by $47 \%$ for a soil temperature change from $12^{\circ} \mathrm{C}$ to $20^{\circ} \mathrm{C}$, but then decreased by about $40 \%$ when the temperature was further increased to $27^{\circ} \mathrm{C}$.? Table 1 summarizes somi recent data besed on field experiments by Boersma. ${ }^{\circ}$

While all yields obtained in these experiments were depresed by water shortage, the growth in the heated corn plots was particularly restricted by insufficient irrigation. Based on the observed rate of yield increase and past experience of corn silage production potential in this region, yields of 13 to 15 tons/acre of dry matter are considered attainable. Soil warming also added to the quality of the product, and the nitrogen content in the silnge was increased.

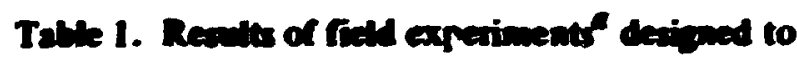
manese the eflect of wainge the soil above its antad temperatures (ref. 10)

\begin{tabular}{|c|c|c|c|}
\hline \multirow{2}{*}{ Crop } & \multicolumn{2}{|c|}{ Yindd (tons/acre) } & \multirow{2}{*}{$\begin{array}{c}\text { Yield } \\
\text { increase } \\
\text { (\%) }\end{array}$} \\
\hline & Unheated & Heated & \\
\hline \multicolumn{4}{|l|}{ Corn } \\
\hline $\begin{array}{l}\text { Singe } \\
\text { Grain }\end{array}$ & $\begin{array}{l}5.5 \\
3.2\end{array}$ & $\begin{array}{l}8.0 \\
4.3\end{array}$ & $\begin{array}{l}45 \\
34\end{array}$ \\
\hline Tomatoes & 321 & 48.3 & so \\
\hline Soybeans, sillore & 2.25 & 3.74 & 66 \\
\hline \multicolumn{4}{|l|}{ Duah beans } \\
\hline $\begin{array}{l}\text { First phntios } \\
\text { Second plantine }\end{array}$ & $\begin{array}{l}6.44 \\
3.30^{6}\end{array}$ & $\begin{array}{l}7.80 \\
5.70\end{array}$ & $\begin{array}{l}21 \\
73\end{array}$ \\
\hline Total & 9.74 & 13.50 & 39 \\
\hline
\end{tabular}

CConducted durine 1969 near Corvaltis, Orepon

bDid not mature. 
Two crops of bush beans were erown in succession on the same area, but the second crop on the unheated area did not mature. The beans harvested on the unheated plots were extremely small and could not have been sold commercially. On the other hand, the second crop on the heated plots was of the same quality 2i the first. Based on these observations, bean yields of 12 to 15 tors/acre, or more than twice the unheated yields, are considered feasible. Even higher yields probabiy can be obtained by asing optimum practices and high density planting.

Improved crop quality. Crop quality is believed to be. in part, a function of the overall plant growth cycle, and therefore control of the ervironment over the plant's lifetime should improve the final product. Little is known, however, about the specific effect of elevated root temperature in commercial crop production. Crop quality may not necescarily be increased, since plant production of certain materials is not ascumed to be a single-valued funition of root temperature over the whole range of plant growth temperatures.

Control diease and pests. Cool soits tend to encour. age certain diseases, particularly in cotton, and coolness also adversely affects the quality of the fiber. The use of water heated above the temrarature usually considered in the "waste heat" range, has been proposed for soin sterilization. For example, the golden nematode (and its egss) are killed by 5 min exposure to water at $125^{\circ} \mathrm{F}\left(49^{\circ} \mathrm{C}\right) .^{\prime \prime}$ With lower temperature exposures $\left(105\right.$ to $110^{\circ} \mathrm{F}$ ) it may take 20 to $60 \mathrm{~min}$ to be lethal. ${ }^{12}$

\section{Curreat Reseorch Programs and Appications}

The importance of soil temperature to plant growth has long been recognized, and research studies of this faxtor have been in progreas since about 1905. A review by Richards, Hagan, and McCalla' summarizes knowtedge of soil temperature as a biological factor up to 1952, and Neilsen and Humphries extend this review to i $766^{3}$ An extensive bibliography (1152 references) on the general subject of sol temperature was prepared by the U.S. Agricultural Research Service in 1964 (W. 0. Willis, "Bibliography on Soil Temperature, through 1963, U.S. Agricultural Resources Service, Sec. 41-94, 1964). The USDA is continuing to sponsor work at several universities and area experiment stations. The work at the Ohio Apricultural Rexearch and Develop ment Center on The Relation of Soil Temperature to Growth and Miretal Absorption by Plants' ${ }^{3}$ is particularly pertinent, as is the work at Oregon State University on Control of Soil Temperature with Reactor Cooting Water. ${ }^{14}$
The states of Washingtion and Oregon have a mumber of programs investigating the aricultural use of $\mathrm{mam}$ water from power enerating stations. Boersmen of Ongon State University has proposed the system shown schernatically in Fig 3 for utilizing (and discipatima) powe plant waste heat. ${ }^{10}$ This system includes two primary means for heat diacipation, sol warming and evaporative cooling. The power phant turbineccondeneer water cooling loop would be a closed recircabating system giving up heat throwh a pipe will to either the soil and/or to water in the eraporative cooling basie. One use proposed for the beated reter from the basin is for treatment of minal waste with alove prodection which, in turn, would be recucled as animed feed supplement. In the sumber the waste stream condd be used for field crop irrieation, and thes many metrients could be returned to the sin. Aliermativety the wase could form the besis for an aquaculhure activity.

In a current experimeatul project supported by the State of Oregon, the USDA, and the Proific Power and Light Company, electric heating cables are uned inutead of buried pipe for sol beatine 10 Prelinimery cop resposase data are reported in Table 1. Dased on projected yield improveneat aed donble cropping of some of the land, a benefit-cont andyis indicates that this system or modif cation of it wing wasm weter way be extremaly attrox ive. In an exingle anbreed, cooling water from a i $00-2$ Wh(e) resctor power station wes assumed to beat the soi on a SOCDecre fan and to provide the water for a s00-ere evoporative coctins system.

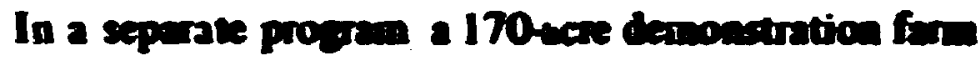
project hos been opersing for there yens at Spinst field, Orepon, sposeored by the Envene Whter and Electric Doerd and anmed by Vitro (Divition of Autometion Indestries)." Prisary enplasis in the experimental propram is on evaluation of the we of warm water ( 90 to 130\%, dbenined from a weaty pols and paper plat) for frout protection, phat coolines and irription." In lects conducted over three full growing

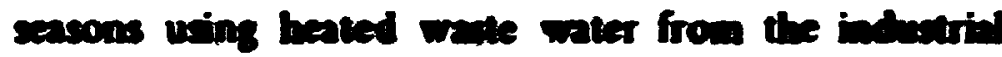
plent for spraying of fruit and out trees, wo crop lows

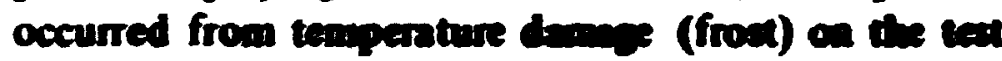
field, while adjecent fields not bing spisyed sofiered

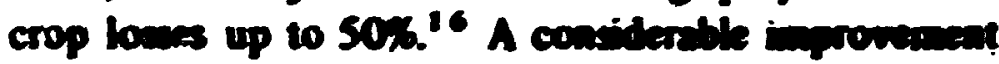
in maturity dates, yields, and pality of severd frets and vecotsbles bas been denomitrated.

Ecosomic studies are in propers at Wathinglon Sable University to evaluste the potentid beanefits to be

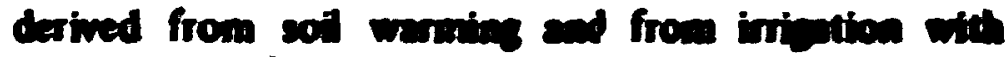
warm water." The andy in in those parts, of whel the

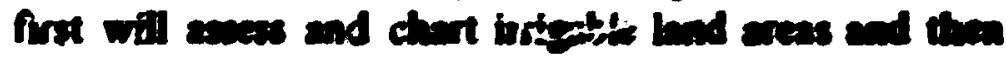




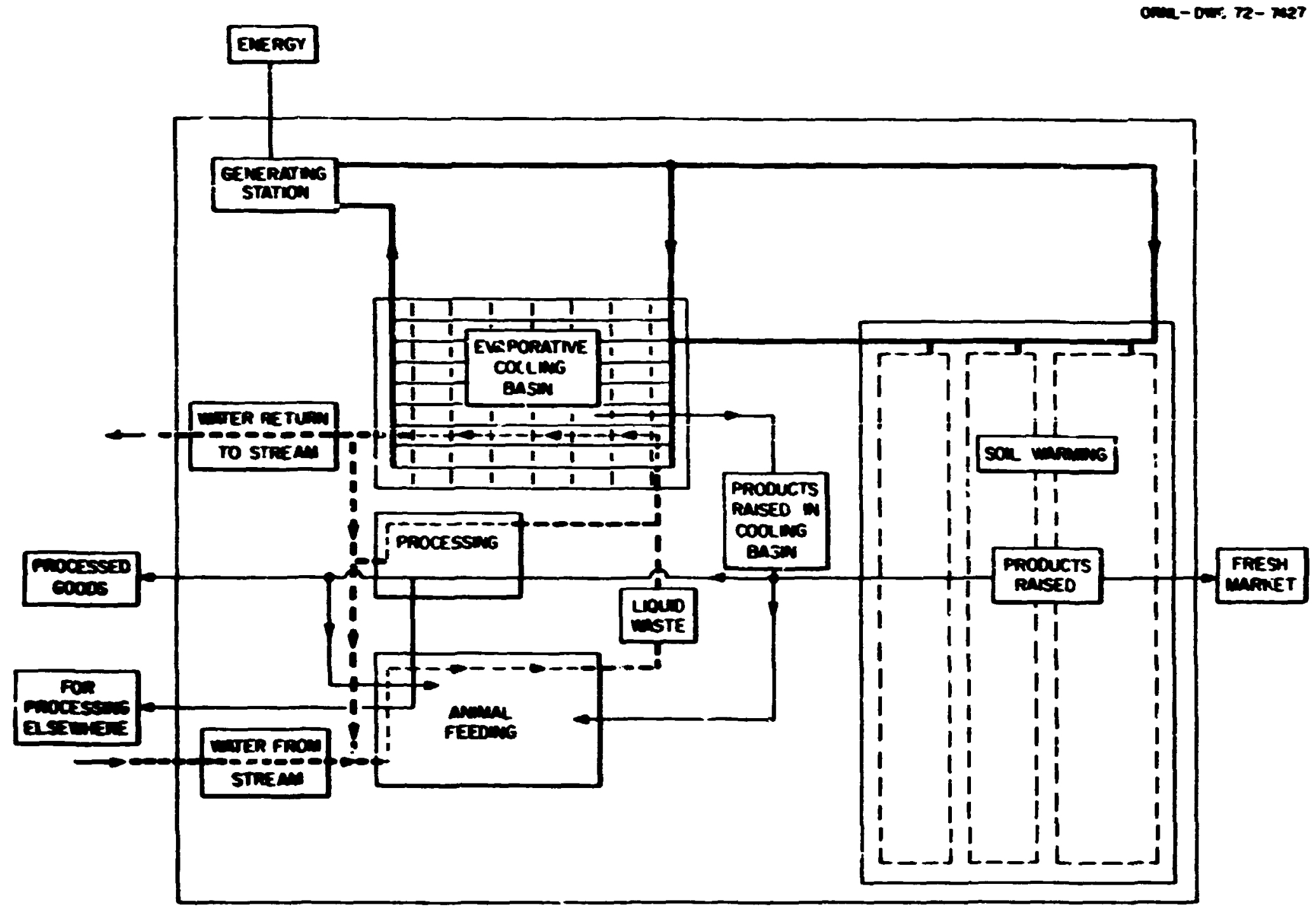

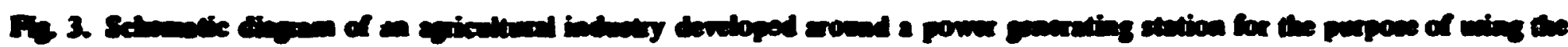

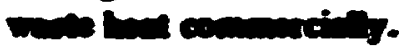

anblish cost-benefit ratios for irrigation. The second pert of the study will predict environmental impacis of werm water additions to land mases. Part three will be a systems analysis of an integrated multiple-use water program.

Theoretical investigations are being carried out at the Univereity of Artanass to analyze the imultaneous movement of heat and moisture in soils.' One pobatial problem in heating soils with buied pipes is that as the soil temperature around the pipe rises, the soi dries out. The dying decreases the soil thermal conductivity and effectively insulates the pipe; this further reduces heat transfer. If the heating could be combined with subsurface irrigation, this problem minter be allevinted. The Western Washington Research and Extension Center is starting an experimental project to study subsurface heating and subsurface iripation. This work is sponsored by Puset Sound . Power and Electric Company.

Fidd experiments are being initiated by North Carobea State University at Raleigh to evaluate the use of waste heat for soil warming in the southeast section of the U.S.' 9 This project has the objectives of determining the feasibility of transferring waste heat to the soil system without crop damage during the hot months and determining the extent to which the soil environment can be modified and plant yields increased during the cooler periods of the year.

As part of the Tennessee Valley Authority's program on waste heat utilization, tests have been conducted on subsoil heating and irrigation to extend the growing season. Heating the soil more than doubled the yield of string beans on both irrigated and nonirrigated soils, and yields of sweet corn were almost doubled.

\section{Pocentin Problect Areas}

Most of the incentives for controlling soil temperature and the resulting benefits are of considerable significance. $A$ basic problem exiats in the economic risks due to the undemonstrated techniques and crop yields on bre farms over extended operating times; that is, the 
overall economics have not been established, particuGrly with regard to the hith initial investment where irrigation would not normally be needed. Also, longterm testing may reveal problems in soil management or plant disease and peat control, although there is presently no indication of such problems.

A significant question appears to exist in the breadth of application of waste heat from power stations for soil temperature manazement or irrigation. Most power stations are located relatively near population centers in areas of adequate rainfall where irrigation is only supplemental. On the other hand, many power stations are located in the higher hatitudes where the soil warming feature could be advantageousty used. Generally, the western part of the U.S. is deficient in rainfall, and particularly in parts of the Northwest both soil warming and irrigation appear to offer good potential for the use of waste heat from power plants.

There are also problems in continuousty utilizing the entire flow of warm water [a 1000-MTM(e) power station would continuousty discharge 500,000 700,000 epm] on nearby farms. However, even if the entire flow could not be distributed continuousty, the careful selection of sites in regions of arid apriculture could benefit large farming areas. Since irrigation results in some comsumption of water by evaporation and transpiration, the use of condenser water on previousty unirigated land might be objectionable. Such a use and its benefits would have to be weighed aginst the alternate choice of wet cooling towers and their water makeup and blowdown requirtments, and the comparison of pumping and piping cost would have to be determined for soil irrigation coolung. In the western states, the availability of water would have to be determined, and legal restrictions would have to be defined. ${ }^{20}$

There may abo be questions raised on the Hirect agricultural use of cooling water from nuciear plants from the standpoint of potential radiosetive contamination. ${ }^{21}$ Special precautions may be necessary to prevent this problem from occurring.

Problems of power plant operation, refueling, shutdowm, and effect on the power conversion cycle efficiency have not yet been adequately andyzed, and additional costs or areas in which research is needed my be revealed.

\section{Concladions}

While agricultural uses for power station waste hest appear to be beneficial, especially for arid sreas where water quality standirds prohibit the retum of beated water to strearns, the current state-of-the-art for openfield use is quite limited. Most of the required research and development areas hwe been identified, and intial results are encouraging. However, areas in which work may be needed are: (1) induced power-station problems such as increased pumping costs, siting restructions, -.tc.; (2) the economics of the total operaison, inchuding marketing and projected price structure of aricultural products; (3) overall ecological effects; (4) additional begl restrictions resulting from the combination of powe production and irriention. Since several of the research and development projects mentioned are beine sponsored by power utility companies, it would be expected that these problem areas are receiving attention, but as yet they have sot been discussed in the literature.

\section{Creenlouses}

The utilization of waste heat for greenhouse opention has been augested in several studies 1,22 ind papers 23-26 recently. Since an exchusion area is required for nuclear power phants, it has been sureseded that greenhouses might be constructed on this idk had coijecent to muckear phnts to use the waste heat from the power phats and under certain circumstances might conceivebly replece cooling tomers which would other. wise be required. ${ }^{23}$ In areas where the heation costs amount to from 10 to $30 \%$ of the operating cont (or $\$ 2000$ to $\$ 11,000 /$ acre) for greeshore production of regetables, the polential reductions in cost of heating provide a considereble incentive to develop lage greenhouse operations in conjunction with power phasts. This arrangement would alow the use of ofherwixe wasted resources (beat and bad) without redbeing the effiziency of the power plant. The increasing dicficulties in obtaining matural gas (a primary fuel for hating in greenbouses) provide additional incentive for boding to the use of waste heat for heating and cooling of greenhouses.

Crop yiett can be geathy inproved throuch the utilization of heat, in costrolledenvironuent of or phatic houses, providing an added incentive for the use of waste heat. However, because une amount of heat available from lore power stations is so great, it is not likely that the cosstruction of greenbouses would be practical for the diaipation of ill the mate heat produced by the power phats being conetructed today.

\section{boentives for Uing Wese Heat is Greenlowes}

The we of greentrounes for the culture of vepetsbles enables laver crope and crop vields (up to 10 times the 
Cpen-field ou'put) to be realized with small amounts of lnd area. In addition, the ability to culture crops the year round allows more uniform productivity and permits the matching of crop harvest with periods of high demand and kigh price. Providing plants with the optimum temperature an reduce the time required to produse a crop and cin greatly improve the yield per plant. Optimum temperatures vary with the species. Vegetables cultured a: vism daytime temperatures of 80 to $100^{\circ} \mathrm{F}$ and menttime temperatures of 75 to $80^{\circ} \mathrm{F}$ indude squash, watermelon, cantaloupe, and cucumbers; those cultured at daytime temperatures of 75 to $85^{\circ} \mathrm{F}$ and 60 to $6 .^{\circ} \mathrm{F}$ nighttime temperatures are tomatoes, peppers, olva, ezsplant, and onions. At low dytime temperatures of 70 to $80^{\circ} \mathrm{F}$ and nightime temperatures of 50 to $60^{\circ} \mathrm{F}$, spinach radishes, cabbage, broccoli, carrot; beans, beets, lettuce, and cauliflower are cultured. 24

Although many crops can be grown ia greenhouses, the differences in value tend to encourage intensive production of only 3 few species. These inchude tomatoes, cucumbers, and lettuce. Growth curves for these three plants are shown in Fig 4. The costs of prodr cing vegetables in greenhouses vary with bcation, but the largest items in the operating costs are ahays bbor and fuel. ${ }^{27,23}$ In Ohio, ${ }^{20}$ Michion, ${ }^{29}$ Minois, ${ }^{27}$ and Ontario, ${ }^{30}$ the heating costs represent $\$ 2000$ to $\$ 11,000 / a c r e$, or 10 to $30 \%$ of the operating cost (depeading on location and crop species). With heating costs reduced, the profits may be increased, or more noney way be available to pay for increased costs of bbor or moterials. The use of waste heat from sean-bectric power plants therefore appears pismiving $x$ a source of bow-cost heat for use in greenhouses,

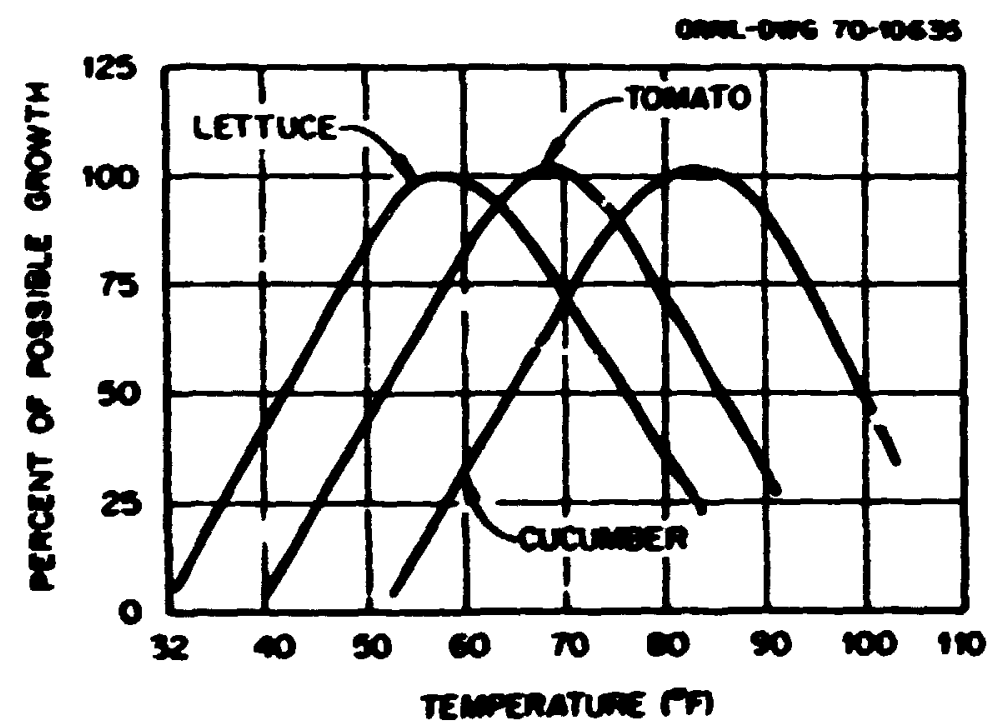

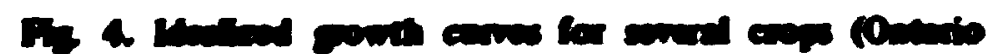

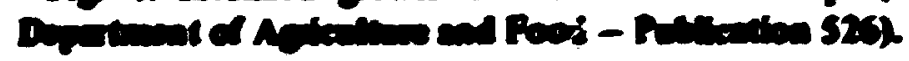

especially if the plants have cooling towers with wintertime operating temperatures of $60^{\circ} \mathrm{F}$ or higher.

Commercial cultivation of tomatoes is usually profitable with heat from fossil-fueted sources at 51 to $51.50 /$ mi.jion Bu. If reactor teat at $20 \% /$ million Btu were available, operating costs in some parts of the country could be reduced by $\$ 4000$ to $\$ 6000 /$ acre. ${ }^{31}$ Capital costs to deliver the heat from the reactor and to provide the necessary emergency heating are estimated at $\mathbf{5 2 8 , 0 0 0 / a c r e ~ ( f o r ~ e a c h ~ 1 0 0 - a c r e ~ i n s t a l l a t i o n ) , ~ a s ~}$ compared with the nomal capital investment in heating equipment of $\$ 15,000$ to $\$ 25,000 /$ acre. $^{23}$ If the heat in warm nater from power pianis could be sold at $206 /$ million Btu to a 500 -acre greenhouse installation, an operating profit to the power plant of $\mathbf{5 0 0}$ thou sand to $\$ 1$ million/year could be realized. ${ }^{31}$

The extensive use of Jeenhouses in or near areas of high population density would permit supplying food to nearby matkets at seasonably favorable periods. Labor is considered the greatest single problem in the industry, and it may limit extensive use of greenhouses in some areas. 31

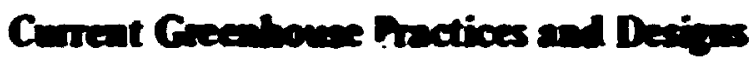

Current greenhouse operations employ either glass or plastic-covered houses. Recent interest in plasticcovered houses results from their bow capital and construction costs and their tax advantage." Develop ments in plastics and the use of twin-tayer plastics for greenhouses have reduced the beating costs by reducing the heat bowes through the roof. Wittwer notes thet doubletaye platic bouses require only is the mount of heat requind for glas houses. Detailed discuscions of greenhouse daipo are avaibble in refs. 33-35.

Creedhouses hive been heated with bot water for many years by using redintors a faned tubes. In adition, weter is often used for coolias with erapo rative pods and fans. Studies hove shown that warm vater in the pad and fan system, in conjunction with finned tubes, can be uned for both summer cooling and wiater beation 31

The bat docunented studies of the use of wate heat in ereenhouses involve the joint efforts of the Uhiver. sity of Arivom and the Univerity of Sosora at Prerto Penasco, Sonora, Mexico. 22 At Sonora the wate heat of dienel exine-penerator sets is und in a dexalting

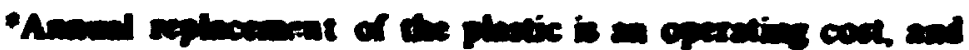

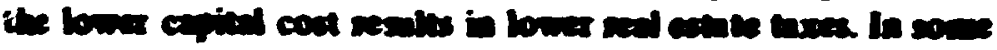

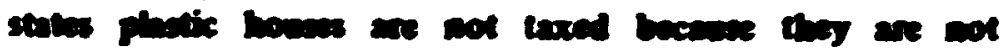

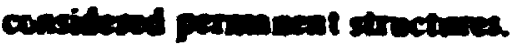


plant and the growing areas of the ccntrolled-environment greenhouses. Environmental control is provided in the University of Arizona experiment by use of a direct-ontact heat exchanger in which air is 'orced through packed columns into which seawater is prayed at the rate of $120 \mathrm{gpm}$ Variation in flow rate is used to regulate the temperature. When warmer temperatures are required, the $94^{\circ} \mathrm{F}$ blowdown water of the desalting plant my be used instead of seawater. In this system the humidity remains at nearly $100 \%$, and the air temperature is close to that of the water passing over the packed-column heat exchangers. Approximately $20,000 \mathrm{cfm}$ of moist air is circulated for ventilation and temperature control in the greenhouses. Warm water from power plants and other industrial processes could be used for such agriculture. 24

A preliminary feasibitity study of the use of warm water for heating and cooling greenhouses in the Dearver aren was carried out by Oak Ridge National Laboratory." The study showed that the rooling tower planned for the 330-MT(e) Fort St. Vrain nuclear plant of the Colorado Public Service Company could be replaced with low-cost (relative to cooling tower capital cost) evaporative heat exchangers located in the greenhouses.** For the design wet bulb temperature in the Denver area $\left(65^{\circ} \mathrm{F}\right)$, calcutations indicated that the ereenhouses could be cooled to at leas $75^{\circ} \mathrm{F}$ in the summer by evaporating $92^{\circ} \mathrm{F}$ water (avalable from the turbine condenser) with once-through air, the beat bein; discharged to the outside. By recirculating the greenhouse air through the evaporative pads during the winter, the air temperature could be maintained above $65^{\circ} \mathrm{F}$ with a $0^{\circ} \mathrm{F}$ outside temperature. In either mxde of operation, heat discipation is constant and "full bad."

In the ORNL design, water is circulated th ough evaporative peds as shown in Fist 5 and 6. Air pascing through the pads is evaporatindy cooled during periods of high ambient temperiture and heated during periods of low ambient temperature. To maintain the bumidity at levets under $80 \%$, fined-sube heat exchangers are plared downstream of the evaporative pads so that dry heat could be added to reduce the air humidity. (Discusions with phent physiologines and borticulturists suent thai plants are more proas to funaus and divense at humidities above 85\%; hence the need for bumidity reduction. However, the University of Arizom epperiments tove been with meaty saturated air.) The witer returning to the condenver approaches the wet balb

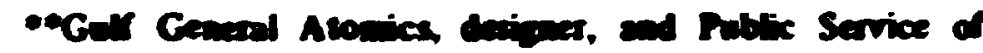

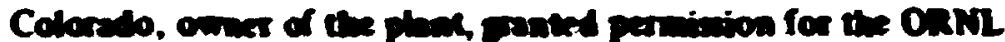

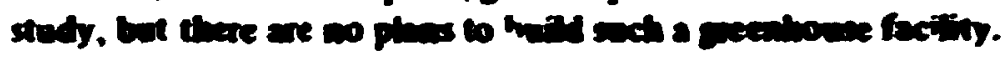

temperature of the air during operation, and the water heats or cools the air moving through the pad, depending on water temperature and entering air temperature conditiors.

Figures 7 and 8 show the greenhouse arrangement. Except for the plastic sheet used for the attic to permit air recycling, the arrangement is fairly typical of bre greenhouse cinits that use evaporative peds for summer cooling. During the summer, air enters the greenhouse through the pads and exhausts at the oppusite end. As outside temperatures drop, the discharge lourres close and force the air to recycle through the attic and subsequently through the evaporative pads. During cold nights the relative humidity of the air leaving the peds is nearly 100\%, and the finned-tube heat exchanger is uned to heat the air to reduce the lumidity in the greenhouse to 80-90\%.

Table 2 gives the calculated air and water conditions for several summer openting cases, with eraporative

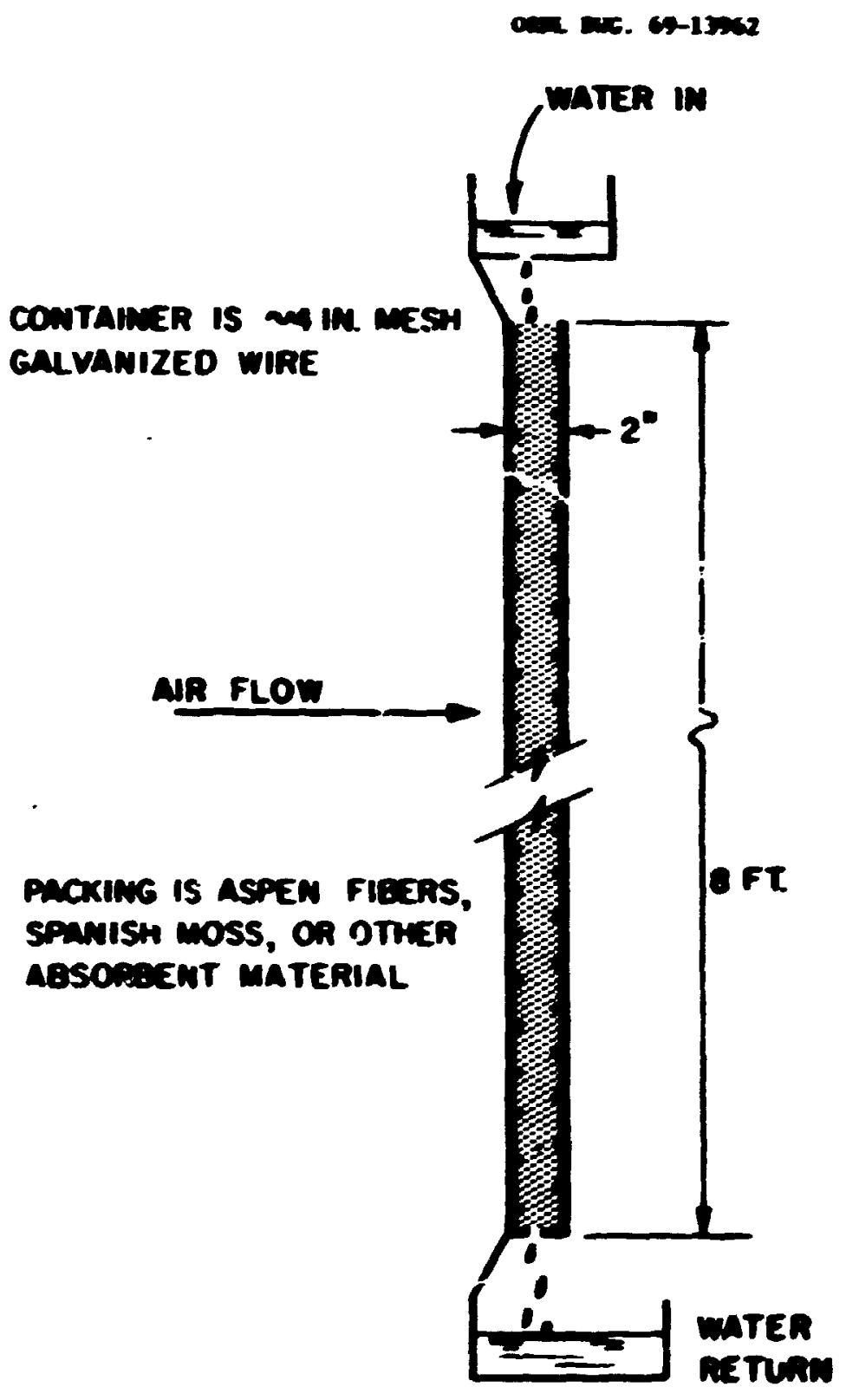

Pis 5. Pol anding. 


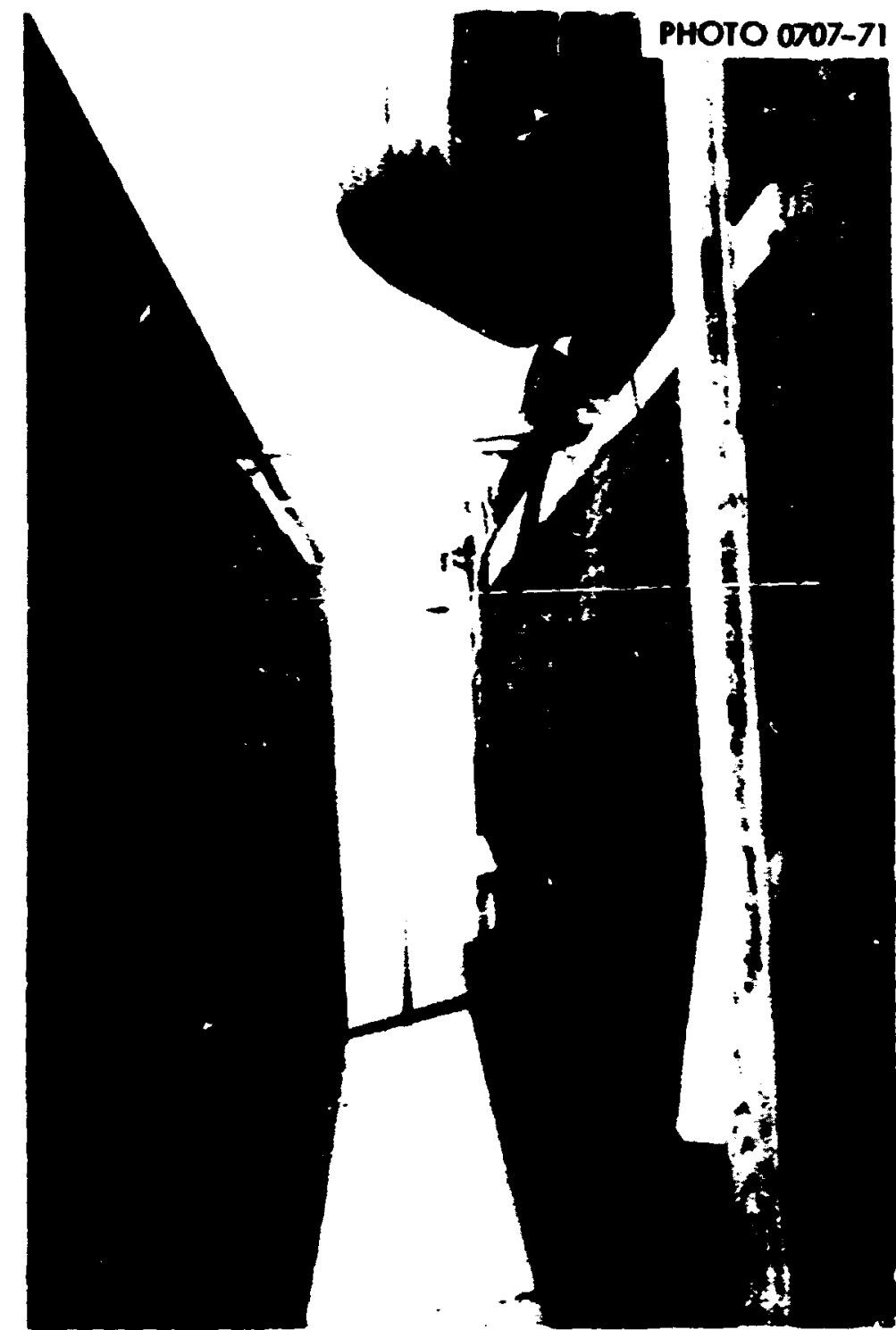

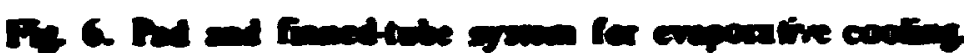

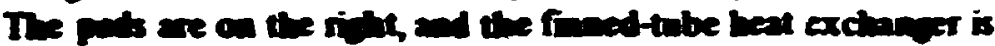
on the wh Air now in from rive co bef. pads replacing the cooling tower of the Fort St. V:ain plant. ${ }^{31}$ It was assumed that hot water from the condenser would be piped directiy to the greenhouses. The flow rates expressed are for each $50 \times 100 \mathrm{it}$ greenhouse. In all cases the range of the temperature is $22^{\circ} \mathrm{F}$, the same as for the Fort St. Vrain plant. which has design temparatures of 80 to $102^{\circ} \mathrm{F}$.

Table 3 gives similar data for winter operating concitions. ${ }^{31}$ Data for wind and sky conditions are also given in the table, and the relationship between the air, water, and roof temperatures is shown. The heat available from the Fort St. Vrain plant would be encugh tor 250 to 300 acres of greenhouses. During the stimmer, water returning to the power plant from the pads would be cooler than would normally be delivered by the existing cooling tower and therefore would increase the efficiency of the plant during hot weather.

Summer cooling conditions are favorable for the Denver area, because of the design wet bulb tempera ture of $65^{\circ} \mathrm{F}$. It should be noted that the water temperature irom the pad approaches the wet bulb temperature of the air within 3 to $5^{\circ} \mathrm{F}$. In areas having a high wet bulb temperature, the cooling effectiveness would be less than in areas with a low wet bulb remperature.

\section{Curreat Developaseat Frogenss}

While there are no large greenhouse operatiens in this country using low-tevel heat from power plants, experimental work is being carried out which could lead to inge-scale use in the future. As mentioned earlier, the

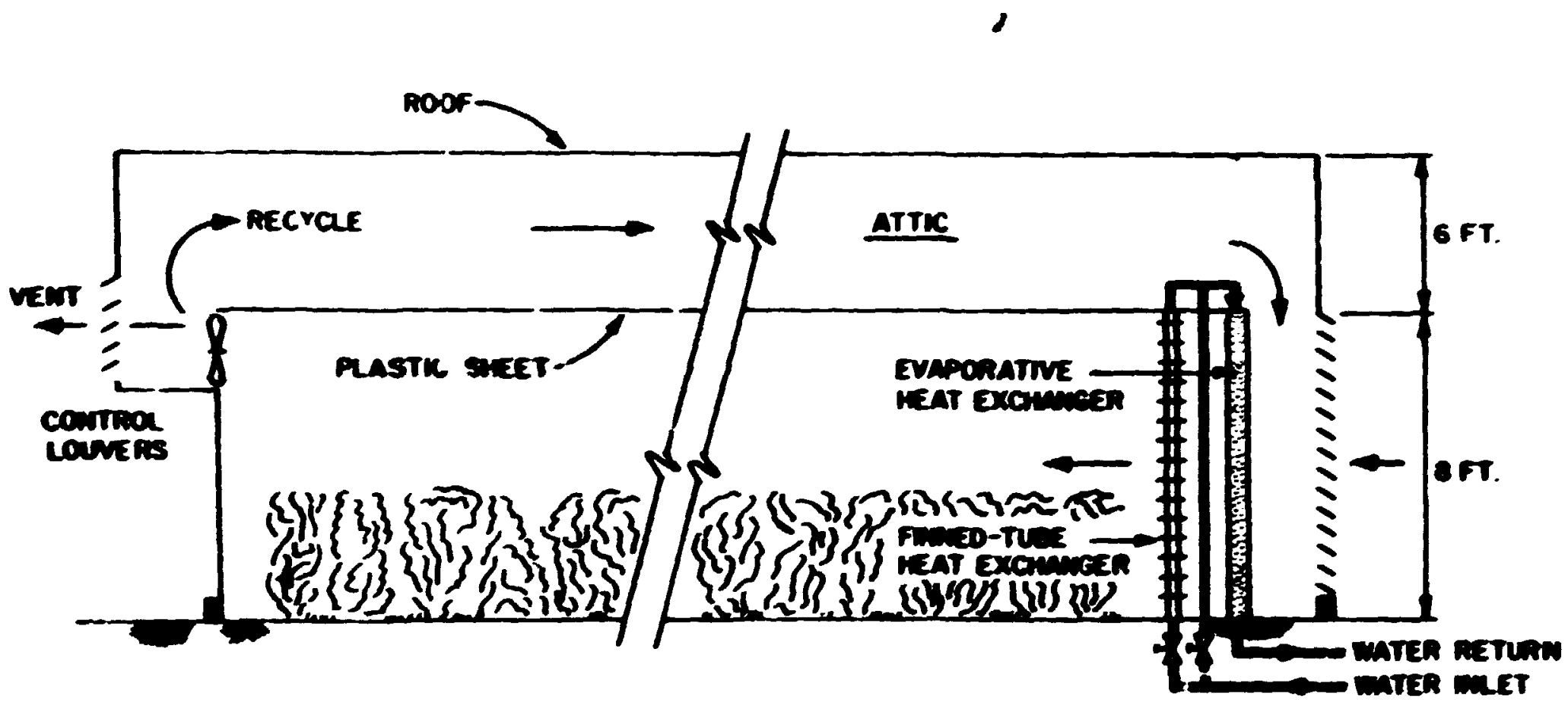

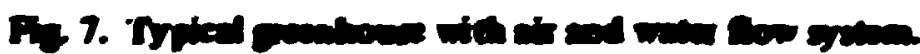




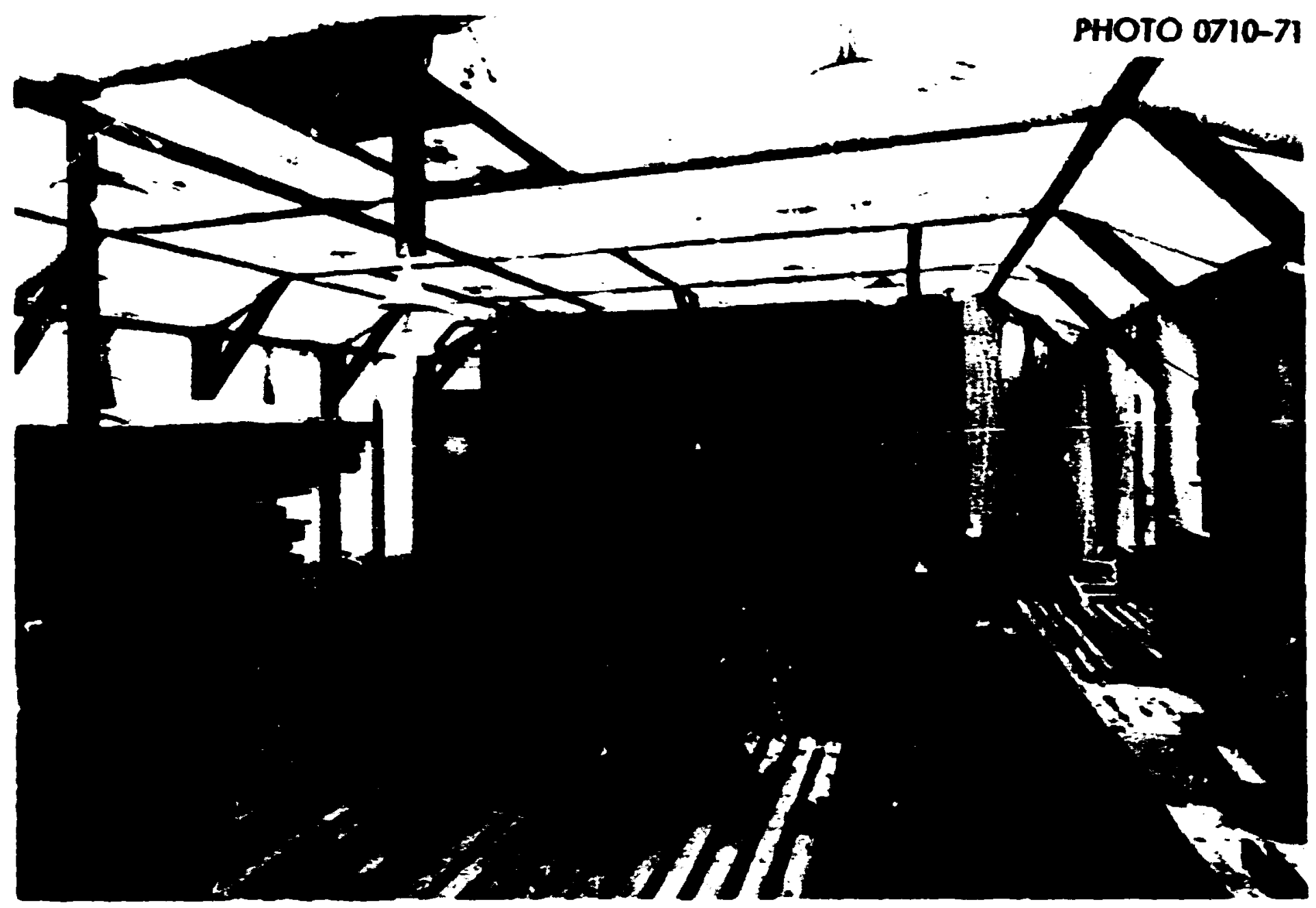

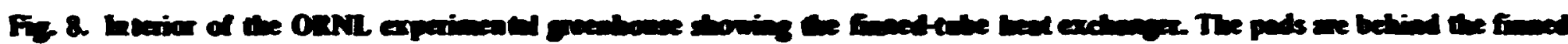
tobes.

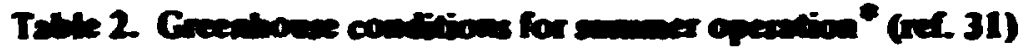

\begin{tabular}{|c|c|c|c|c|c|c|c|}
\hline \multirow{2}{*}{ Care } & \multicolumn{2}{|c|}{$\begin{array}{l}\text { Ambieat } \\
\text { conditions }\end{array}$} & \multirow{2}{*}{ 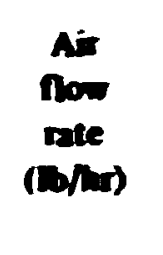 } & \multirow{2}{*}{$\begin{array}{l}\text { Water } \\
\text { now } \\
\text { rate } \\
\text { (borla) }\end{array}$} & \multicolumn{2}{|c|}{ 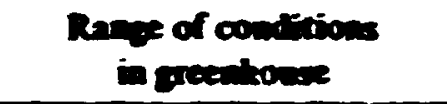 } & \multirow{2}{*}{ 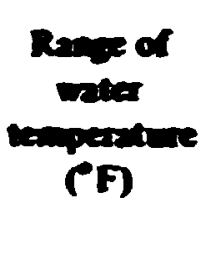 } \\
\hline & $\begin{array}{c}\text { Drs bus } \\
\text { temperature } \\
P F\end{array}$ & $\begin{array}{l}\text { Retonive } \\
\text { (s) }\end{array}$ & & & $\begin{array}{c}\text { Temperdine } \\
\text { (P) }\end{array}$ & $\begin{array}{l}\text { Relacine } \\
\text { (B) }\end{array}$ & \\
\hline $1^{e}$ & 95 & 16 & 305,000 & 80,200 & $76-86$ & $8-67$ & $67-69$ \\
\hline $2^{b}$ & so & 73 & 305.000 & 83.200 & -58 & -95 & $51-73$ \\
\hline $3^{b . c}$ & 50 & 73 & 153000 & 82,200 & -67 & -100 & $57-79$ \\
\hline 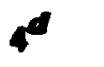 & 95 & 16 & 305.000 & 44,100 & $71-81$ & $85-71$ & c4-es \\
\hline $5^{e}$ & 50 & 73 & 306,000 & 4.100 & -53 & $-\infty 0$ & $48-70$ \\
\hline 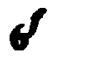 & 50 & 73 & 153.000 & 4,100 & -57 & -100 & $50-72$ \\
\hline
\end{tabular}

"Data are for each $50 \times 100$ fi preenimose

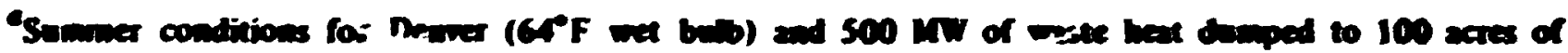
greentromex.

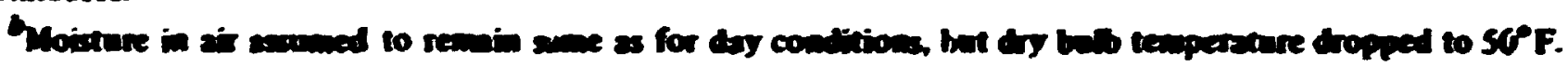

CAir thow rate rediced by onebrit.

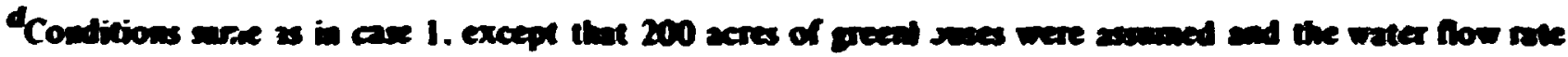
wes redeced by sonethis.

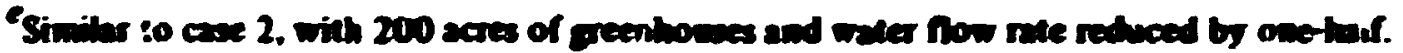

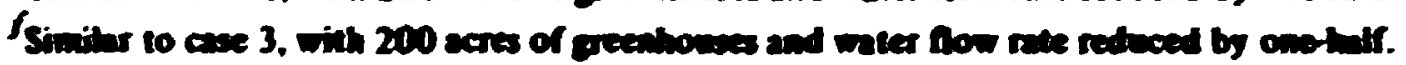


Table 3. Grealhouse conditions for winter operation " (nef. 31)

Wind velocity: $15 \mathrm{mph}$

Effective sky temperature: $-100^{\circ} \mathrm{F}$

Greenhouse area: 200 acres

\begin{tabular}{|c|c|c|c|c|c|c|c|}
\hline \multirow{2}{*}{$\begin{array}{l}\text { Outside } \\
\text { is } \\
\text { :empeenture } \\
\text { ('F) }\end{array}$} & \multirow{2}{*}{$\begin{array}{l}\text { Wiater } \\
\text { flow } \\
\text { rate } \\
(\mathrm{b} / \mathrm{hr})\end{array}$} & \multicolumn{2}{|c|}{$\begin{array}{c}\text { Air flow tate } \\
(\mathbf{m b} / \mathbf{h r})\end{array}$} & \multicolumn{2}{|c|}{$\begin{array}{c}\text { Air temperature } \\
\text { ( F) }\end{array}$} & \multirow{2}{*}{$\begin{array}{c}\text { Range } \\
\text { of } \\
\text { water } \\
\text { temperature } \\
\left.\text { ( }^{\circ} \mathrm{F}\right) \\
\end{array}$} & \multirow{2}{*}{$\begin{array}{l}\text { Mean } \\
\text { roof } \\
\text { temperature } \\
(F)\end{array}$} \\
\hline & & Recycte & Vent & $\begin{array}{l}\text { Over } \\
\text { phants }\end{array}$ & $\begin{array}{l}\text { Through } \\
\text { attic }\end{array}$ & & \\
\hline-30 & $M, 100$ & 153.000 & 3 & 12 & $72-65$ & $66-88$ & 1 \\
\hline-15 & 44,100 & 153,000 & $\mathbf{0}$ & 76 & $76-69$ & $71-93$ & 15 \\
\hline$n$ & 44,100 & 153,000 & $\mathbf{0}$ & 80 & $80-74$ & $75-97$ & 26.5 \\
\hline $\boldsymbol{v}$ & 4,100 & 148,400 & 4,600 & 72 & $72-65$ & $66-88$ & 21 \\
\hline 0 & 4,100 & 141,400 & 11,600 & 63 & $62-56$ & $56-78$ & 15 \\
\hline $\boldsymbol{\sigma}$ & 26,500 & 153,000 & 0 & 56 & $56-50$ & $51-73$ & 12 \\
\hline$\sigma$ & 26,500 & $148,4 r 0$ & 4,600 & 51 & $51-4$ & $45-67$ & 8.5 \\
\hline
\end{tabular}

Uni naxity of Arizon and the University of Sonora are ustre heat from diesel generators to provide heat for grosnhouses at Puerto Penaco, Sonora, Mexico, where creps luave been grown at near $100 \%$ relative humid. iky.22.:6 The success led to a request from the Staikhdom of Abu Dhabi for construction of a S-acre fasility on the island of Sa'Diyat in Abu Dhabi, and this ystem is now in operation. ${ }^{26}$

One of the unique leatures is the ability of the facility (1) conserve water throusin collection of the condensaie which occurs on the plastic roof. It is reported that esch $4500-\mathrm{ft}^{2}$ greenhouse will yiols up to $1500 \mathrm{gl} \mathrm{of}$ iver per day durine periods when the exterior temper. Atures are low enough to result in condensation on the inaide of the plastic roof. ${ }^{26}$ Since this is distilicd water which can be recovered and used for makeup water, duries the winter there would be a potential recovery of water amountine tis $\$ 14.2$ thousand gallons per acre of zeenhouse per day. This water could also 80 to supplying the approximstely 10 thousand gallons per acre per day irrigation needs of the crops being raised, and to provide hidh-quality makeup water for the power plant couling system.

Athough the ORNL feasibiliy study"1 described exlier indicates that several acvantages exist for uxins grenhoures to cool reactor condenser water, no plans exiat to indicate that greenhouxs will be built in the U.S. to use a suzable portion of power plant waste heat. However, regardless of wheiher the power plant is cooled significantly. even a fraction of the heat should be an aitraction io a greenhouse operator because of Suw heat costs. Yurthermore, there are many industrial processes and cooling towers wasting heat which could te used in greenhouses at a small expense to the grower. Recently, an experiment was star:El at Oak Ridge to determine the actual operating periormance of a pad and fan system for use in heating and cooling greenhouses. Waste heat in the water from a building air-conditioning system is being used for temperature control in a small plastic greenhouse. Preliminary iesults thus far have revealed small differences betyreen the theoretical calculations ured in the feasibility study and the pad performance, but additional work is required to prove details of the system. The Tennessec valiey Authority is planning a pilot test of the "Oak Ridye System" of heating and cooling in a joint TVA-ORNL program 25

Each of the systems mentioned involves the flow of water from the power plant to the greenhouse, where tax water is cooled and -nt back to the power plant or discharged to surface ers. The systems available for blending and controlliug the water to maintain certain temperatures require conventional engineering. The use of geenhouses in series or parallel with cooling towers, cooling ponds, or other systems cuuld afford increased lexibility for waste heat ise.

Although work is being conducted throughout the United States on desion of geenhouses, ereenhouse 
equipment, and on growing methods, little work hav direct applicability to the utilization of waste or low-temperature heat from power plants is currently under way. Sufficient information exists to design a greenhouse system to use waste heat. However, the integrated performance of large complex ss may require on-site demonstration facilities before ruany questions can be answered.

\section{Economics of Greenhouse Operation}

Incentives for the utilization of low-temperature heat from powar plants include the legal restrainte on heatcd discharge water to water bodies, the economic potentiai to the utility for the sale of heated effluents, and the reduction in heating costs to the greenhouse operator. For the nation, such use could result in some improvement in national energy utilization.

The economic and marketing incentives for greenhouse products deserve some attention. Current greenhouse tomato production is distributed in the United States as shown in Fig. 9. Most production is in areas having high population densities and represents greenhouse operations of 5 acres or less, with an average being about 1 acre.
The costs and net return for greenhouse tomato projuction are illustrated by the data in Tables 4 and 5 , which are for operations in the U.S., ${ }^{27.29}$ Canada, 30 and Freat Britain. ${ }^{36}$ Table 6 illustrates the investnent, production costs, and returns for flower production. ${ }^{37}$ In the data presented, the investment and operating

Table 4. Approximate annual operating costs to produce two tomato crops per acre

\begin{tabular}{|c|c|c|}
\hline \multirow[t]{2}{*}{ Illinois' } & $\begin{array}{l}\text { Labor } \\
\text { Fuel }\end{array}$ & $\begin{array}{r}4,800-6,720 \\
2,500-3,500\end{array}$ \\
\hline & Totar & \& $9,025-12.700$ \\
\hline \multirow[t]{2}{*}{ Ontario $^{2}$} & $\begin{array}{l}\text { Labor } \\
\text { Fuel }\end{array}$ & s $\begin{array}{r}7,730 \\
5,957\end{array}$ \\
\hline & Totar & $\$ 19,320$ \\
\hline \multicolumn{3}{|c|}{ Great Britain ${ }^{3}$} \\
\hline & Totar & $\$ 14,520-21,780$ \\
\hline $\begin{array}{l}{ }^{1} \text { Cour } \\
{ }^{2} \text { Fisel } \\
{ }^{3} \text { Shen } \\
{ }^{1} \text { Rep }\end{array}$ & & jisst $t$ \\
\hline
\end{tabular}

ONNL-OW6 72-7421

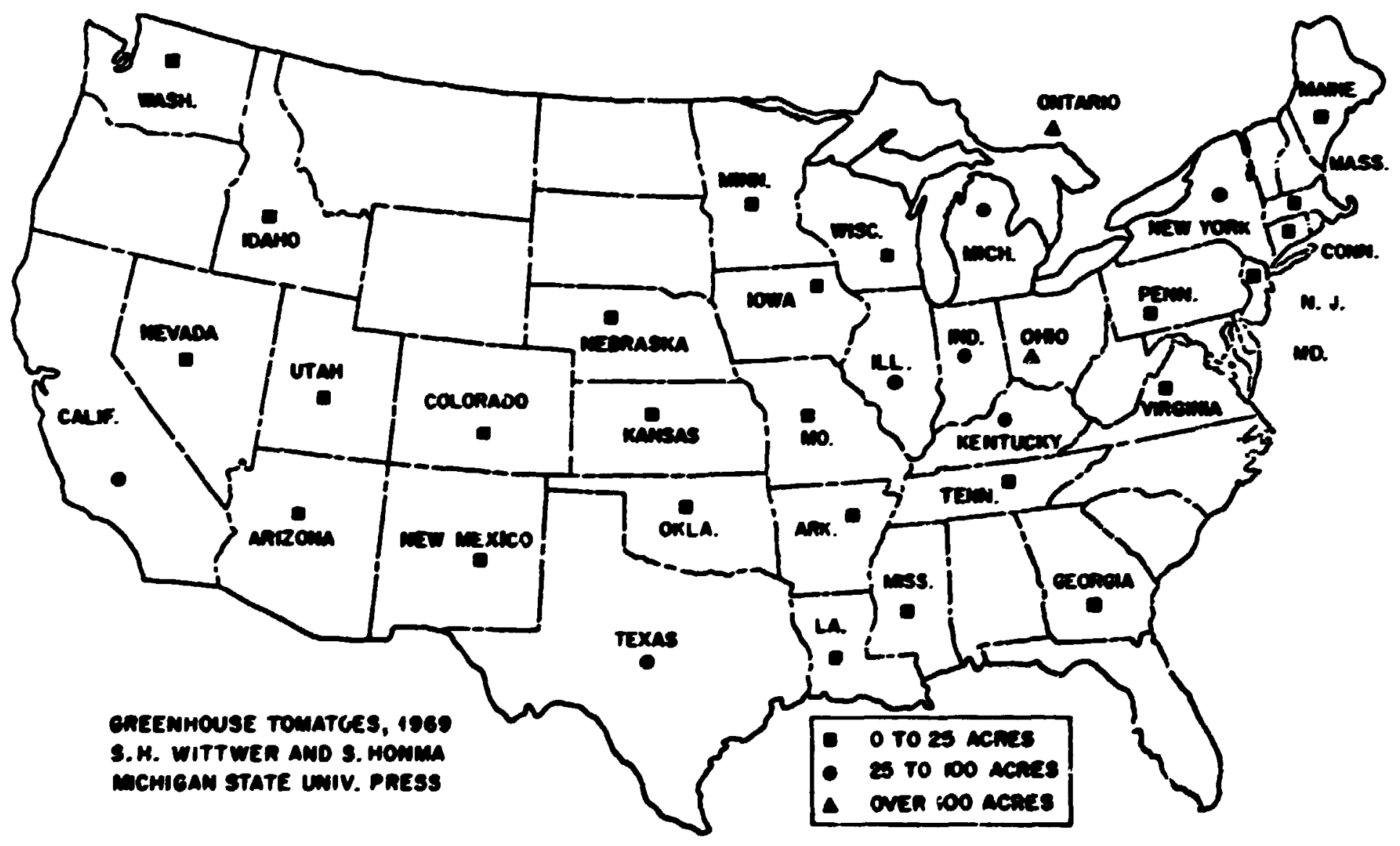

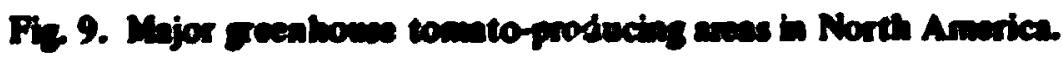


Table 5. Estimated met retures for bbor and manpencent for production of 1 acre of preeshome tomatoes"

\begin{tabular}{lrcc}
\hline Item & Gbass & \multicolumn{1}{c}{$\begin{array}{c}\text { Semipermanent } \\
\text { phastic }\end{array}$} & $\begin{array}{c}\text { Temporary } \\
\text { phastic }\end{array}$ \\
\hline Fixed costs & $\$ 8,175-11,150$ & $\$ 7,325-9,050$ & $\$ 6,000-8,650$ \\
$\begin{array}{c}\text { Openting costs } \\
\text { Total costs }\end{array}$ & $\frac{9,025-12,790}{\$ 17,200-23,940}$ & $\frac{9,025-12,790}{\$ 16,350-21,840}$ & $\frac{9,025-12,790}{\$ 15,025-21,440}$ \\
$\begin{array}{c}\text { Gross cost returns less } \\
\text { direct marketing costs }\end{array}$ & $\$ 27,940-33,000$ & $\$ 27,940-33,000$ & $\$ 27,940-33,000$ \\
$\begin{array}{c}\text { Net returns to bbor } \\
\text { and management }\end{array}$ & $\$ 4,000-15,900$ & $\$ 6,100-16,650$ & $\$ 6,500-17,975$ \\
\hline
\end{tabular}

* Courter (1965).

aCalsulated for a production of $20 \mathrm{lb}$ per phant, for total production from two crops per year, at an averzege price of $\$ 1.75$ to $\$ 2.00$ per $8-1 \mathrm{~b}$ bastet.

\begin{tabular}{|c|c|c|}
\hline Labor costs & $\begin{array}{l}1966 \\
1968-1969\end{array}$ & $\begin{array}{r}\$ 31,076 \\
31,697\end{array}$ \\
\hline Heating & $\begin{array}{l}1966 \\
1968-1969\end{array}$ & $\begin{array}{l}8,496 \\
9,941\end{array}$ \\
\hline Total costs & $\begin{array}{l}1966 \\
1968-1969\end{array}$ & $\begin{array}{l}88,140 \\
85,744\end{array}$ \\
\hline Net returms & $\begin{array}{l}1066 \\
=968-1969\end{array}$ & $\begin{array}{l}2,167 \\
3,252\end{array}$ \\
\hline
\end{tabular}

* "Report of Greenhouse Flower Production in Ontario Production Couts, Returns and Management Practices." 1970. Farm Economics, Co-operative and Statistics Branch, Ontario Department of Agriculture and Food, Chatham, Ontario.

expenses to provide heat represent sizable fractions of the total expense.

An examination of the data from experiments at Puerto Penasco 22,24,26 indicates that annual yields in greenhouse culture are as much as i0 times greater than for open-field culture; prices fluctuate, however, and the profit from a crop is determined not only by the yield and the value per unit but also by the expense of production. Fluctuation in the value of tomatoes is illustrated by Fig. 10. For the large-scale greenhouse facilities considered in the ORNL study of Fort St. Vrain, ${ }^{31}$ a proposed mixture of s.rops that might be raised was suggested and is shown in Table 7. Also shown are potential yields and crop value.

Reasonable profits can be realized from larze-scale greenhouse vegetable operation; however, current pro-

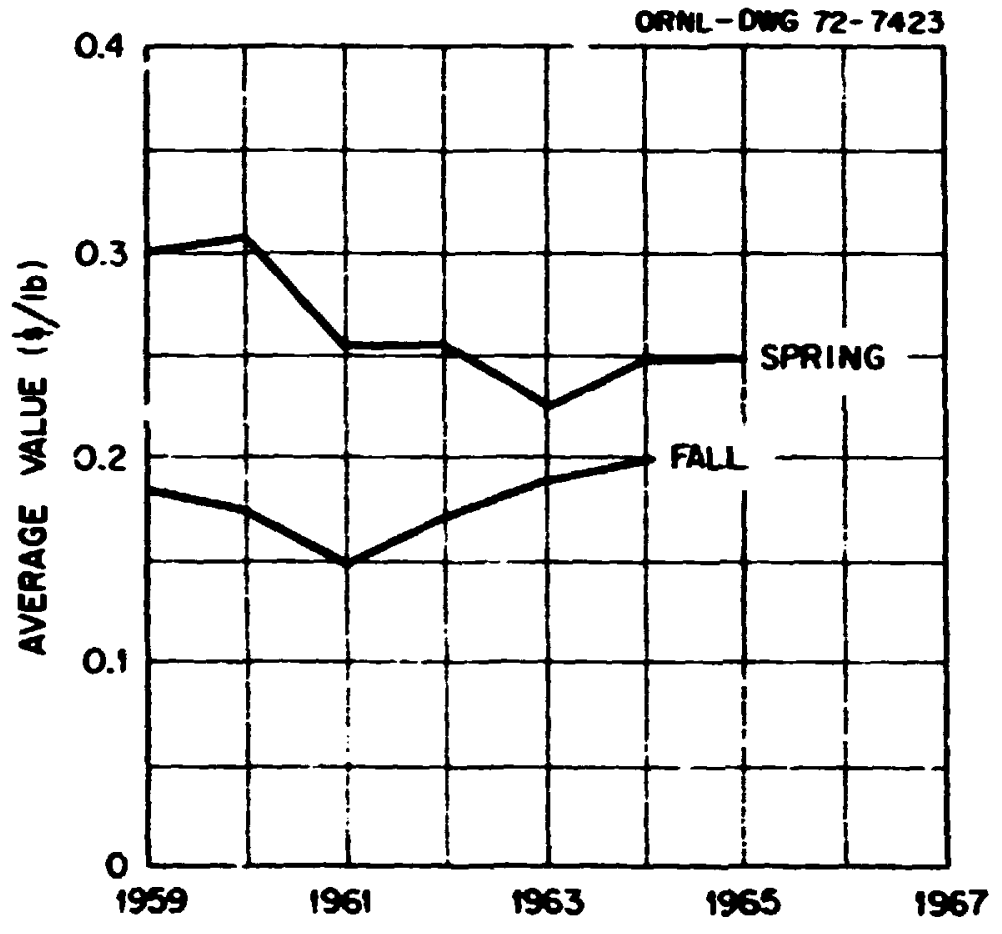

Fie 10. Avereg grom manes recivad for tomatoes 29

duction costs are high and returns are unpredictable, so the risk inyived is high. The operation of such large-scale facilities by integrated companies would reduce the risks. The companies could raise the product, nwn the processing plant, renovate the processing water with waste heat, and have their own market outlet.

\section{Evaluation and Sumanary of Use of Weste Heat for Creenbouses}

A principal advantage of using waste heat from power plants for geenhouses is that it does not require 


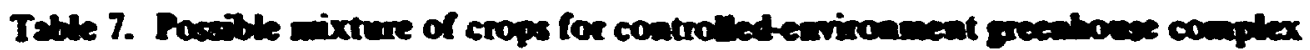

\begin{tabular}{|c|c|c|c|c|c|c|c|}
\hline Crop & $\begin{array}{l}\text { Days } \\
\text { required } \\
\text { per crop }\end{array}$ & $\begin{array}{l}\text { Yiedd per } \\
\text { crop-2cre }\end{array}$ & $\begin{array}{c}\text { Crops } \\
\text { per } \\
\text { year }\end{array}$ & $\begin{array}{l}\text { Yield per } \\
\text { acre-year }\end{array}$ & $\begin{array}{l}\text { Wholesale value } \\
\text { per acre-yearb }\end{array}$ & $\begin{array}{l}\text { Acres } \\
\text { ascigned }\end{array}$ & $\begin{array}{l}\text { Total } \\
\text { value }\end{array}$ \\
\hline Cucumbers & 100 & $144,000 \mathrm{bb}$ & 3.6 & $518,000 \mathrm{Bb}$ & $\$ 31,030$ at $6 \$ 1 / 0$ & so & $\$ 1,554,000$ \\
\hline Ezophants & 130 & $24,000 \mathrm{BD}$ & 2.7 & $67,500 \mathrm{Bb}$ & 5,400 at $84 / 10$ & so & 270,000 \\
\hline Lettuce (lean) & 40 & 84,000 heads & 9 & 756,000 heads & 37,800 at $58 /$ head & 100 & $3,780,000$ \\
\hline Bell peppers & 146 & $30,000 \mathrm{Bb}$ & 2.5 & $75,000 \mathrm{Bb}$ & 9,000 at $12 d / 16$ & so & 450,000 \\
\hline Radishes & 30 & 40,000 bunches & 12 & 480,000 bunches & 24,000 at $5 \$$ /bunch & 5 & 120,000 \\
\hline Squash & 105 & $22,200 \mathrm{~B}$ & 3.6 & $90,000 \mathrm{Bb}$ & 12,000 at $15 / 110$ & so & 600,000 \\
\hline Tomatoes & 140 & $92,000 \mathrm{Bb}$ & 2.5 & $230,000 \mathrm{Bb}$ & 25,300 at $11 / 1 / 6$ & 100 & $2,530,000$ \\
\hline Flowers & 180 & 40,000 plants & 2 & 80,000 plants & 20,000 at $25 / / p h a n t$ & so & $1,000,000$ \\
\hline \multirow[t]{4}{*}{ Strawberries } & 180 & $40,000 \mathrm{BD}$ & 2 & $80.000 \mathrm{Bb}$ & 17.600 at 22d/10 & 50 & sen,040 \\
\hline & & & & & & 305 & $\$ 11,184,000$ \\
\hline & & & \multirow{2}{*}{\multicolumn{2}{|c|}{ Projected average value: }} & \multirow{2}{*}{\multicolumn{2}{|c|}{$\underline{0}=\$ 22,146 / 2 c r e$}} & \\
\hline & & & & & & & \\
\hline
\end{tabular}

\footnotetext{
Winter season, Puerto Penasco Experiment Station, Sonora, Mexico.

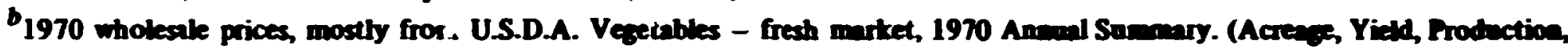
Vilve. These represent the amount received for outdoor crops.)

CFor areas of the country having bigh bight intensity, low choud cover, and near uniform day benth.
}

modification of the plant and does not reduce power cjcle efficiency. The application is one of several options available for the dissipation of waste heat produced during thi production of electric power or other industrial processes. However, if all of the commercial greenhousses existing in the United States today used waste heat, they would consume only a few percent of the heat being wasted from existing power plants. Since the growth rate for power plants exceeds the present growth rate for greenhouses, it is questionable whether more than 1-5\% of the total waste beat could be utilized by greenhouses, and therefore the primary incentives must be economic rather than a solution to the thermal discharge problem.

Although a large amount of water would be consumed in greenhouse operation, water loses would be less than for cooling towers if the water condensing on the greenhouse surface were collected and returned As described earlier, during recirculation in winter, most of the water could be recovered from condensation in the attic.

In the studies at Puerto Penasco, ${ }^{22,16}$ the closed environment itself greatly improved the yields of a wide variety of crops even though relative humidity was rearly 100\%. Mox succescful varieties were those developed in hot humid areas. Tomsato varieties arch as Floradel, N-65, and Tropic did well, while varieties auch as Mlichign. Ohio, Wolverine 119, and. Tuckerom-0 did not. Whether operation at $100 \%$ humidity is posible, in colder cloudy areas of the country and with other verieties, renuins to be seen. High humidity at night can result in the collection of water on the leaves of plants. This may result in growth of fungi and the spread of bacteria which are likely to be detrimental to the phant.

During winter the greenhwuse operator must depend on a reliable supply of heat. At power sites with multiple units the reliabitity of the heat suppty should be high. During scheduled or unscheduled outages of a unit, heated water would be available from ahtermate operating units. Base-load nuclear phnts with high reliability seem aptly suited to the greenhouse requirements. Nuclear stations are equipped with a fosilfired heater of $100 \mathrm{MW}$ or more, which would provide additional reliability. In some cases a separate emergency heating unit would have to be provided.

The use of low-temperature heat therefore represents a potential way of signifiantly reducing operating expenses and increasing proit for the gower. A very lare greenhouse operation could in tum reduce the capital investment and operating expense of the power plant operator by providing a sulstitute heat rejection system and a market for previousty wasted beated water. Thus gins might be realized by both parties in a ereenhouse operation large enough to use a sizable fraction of the waste heat from a power station, bit the invesiment required would be larev. For example, don 
houses which used one-fourth of the waste heat from a 100-MM(e) power plant would require a capital investment of approximately $\$ 25$ million and occupy about $\mathbf{2 5 0}$ acres. Although no such large installations are expected for many years in the United States, it is reporied that single operations of 250 acres exist in Hung:y.*

Lit'le work has been done to date on the evaluation of the market for greenhouse-produced crops at the scale necessary for using such massive quantities of waste heat. Most of the existing data are extrapolated from small-scale operations of $S$ acres or less.

There are many unanswered questions coscerning the use of waste heat from power plants. Chemicals such as chromates used for water treatment in the cooling water system might affect the piants in a greenhouse. Similarly, the pollen from the greenhouic civici possibhy affect the cooling system. The determination of whether such effects will or.ur requires experimental sudies. In the case of nuclear plants the real and imagized hazards of recioactivity must be considered, and public acceptance of products produced in such greenhouse complexes would have to be analyzed. Potential ssurces of activity in the cooling water would hove to be considered and measuring devices installed to contmuously monitor the water for radioactivity.

The most difficult questions to resolve appear to be those of institutional arrangements neccseary for the financins and operating of such an enterprise in conjunction with the operating of a power plant. The organization and training of the greenhouse operating teams, agreements with the utility on shutdown schedwies, proviaion for auxiliary heat supply. and protection of the fower plant coolants from loss or fouling are several of the important problems. If risk insurance is common to greenhouse operation, the degree to which it might be affected by coupling to a power plant for heat would have to be determined.

All of these questions point to the necessity of conducting research or studies to resolve uncertainties which now exist. Ath:ough engineering questions can be recolved fairly easily, these and the biological and economic questions require demonstration projects with crops in a grenhouse facility.

Marketing data, legal restrictions, economic incenives, insurance, apt other questions need extensive probing before the sull potential can be ascertained Labor is considered the number one problem. ${ }^{32}$ Prob-

- Proconal commuaication, J. A. Deum (Vockamp En Vrejland N.V. The Netherlads) fo S. E. Beall (ORNL), 1971. lems of providing the large stilled staff necesary for a successful operation must be investigated and solved.

\section{Conducions}

Adequate enginer.ing informaticht is available to allow the desien and operation of a heating and cooling system for greenhouses utilizing waste heat from steam-dectric power plants. Prospects and incentives exist for the coupling of greenhouse vegetable operation with eleztric power production. The principal uncertainties are in the matseting problems related to high production rates, institutional arrangements for implementing such a program, and the problem of public acceptance of the product.

Presenuly there is need for detailed examination of the operation of a large-seale greenhouse complex in order to resolve these questions.

\section{Animal Shelters}

The feed efficiency (pounds pin/pound feed) and growth rate of some farm animals are strongly dependent on environmental temperature. Proper temperature control can decrease feed consumption and increase productivity. This is particularly important for small animals (with a large surface area to volume ratio) such as poultry and swine, and considerably less important for cows. Because the production of other farm animals (e.f, sheep, goats) is small, only poultry and swine production will be discused here.

\section{Poeltiry Opentiose}

During the past several decades, broiler production has become concentrated in fewer, but larger, farms.** A typical operation today might produce 40,000 io 100,000 birds annually. Broiler production has grown spectacularly in recent years, from 6 billion pounds in 1960 to 11 billion pounds in 1970, an increase of $80 \% 3^{30}$ In rccent years, broiler prices have decreased; see Fig. 11 .

Table 8 lists the eight leading states in broiler piuduction. Production is heavily concentrated in the Southeast; almsst $60 \%$ are grown in Georgia, Arkamsas, Alabami, North Carolina, and Misciscippi. The reasons for this geographic concentration are probably related to low labor costs and a warm climate.

\footnotetext{
* Epglaying bens are not diccused here becanse their supplesientul thermal soquirements are $20 \mathrm{low}$.
} 


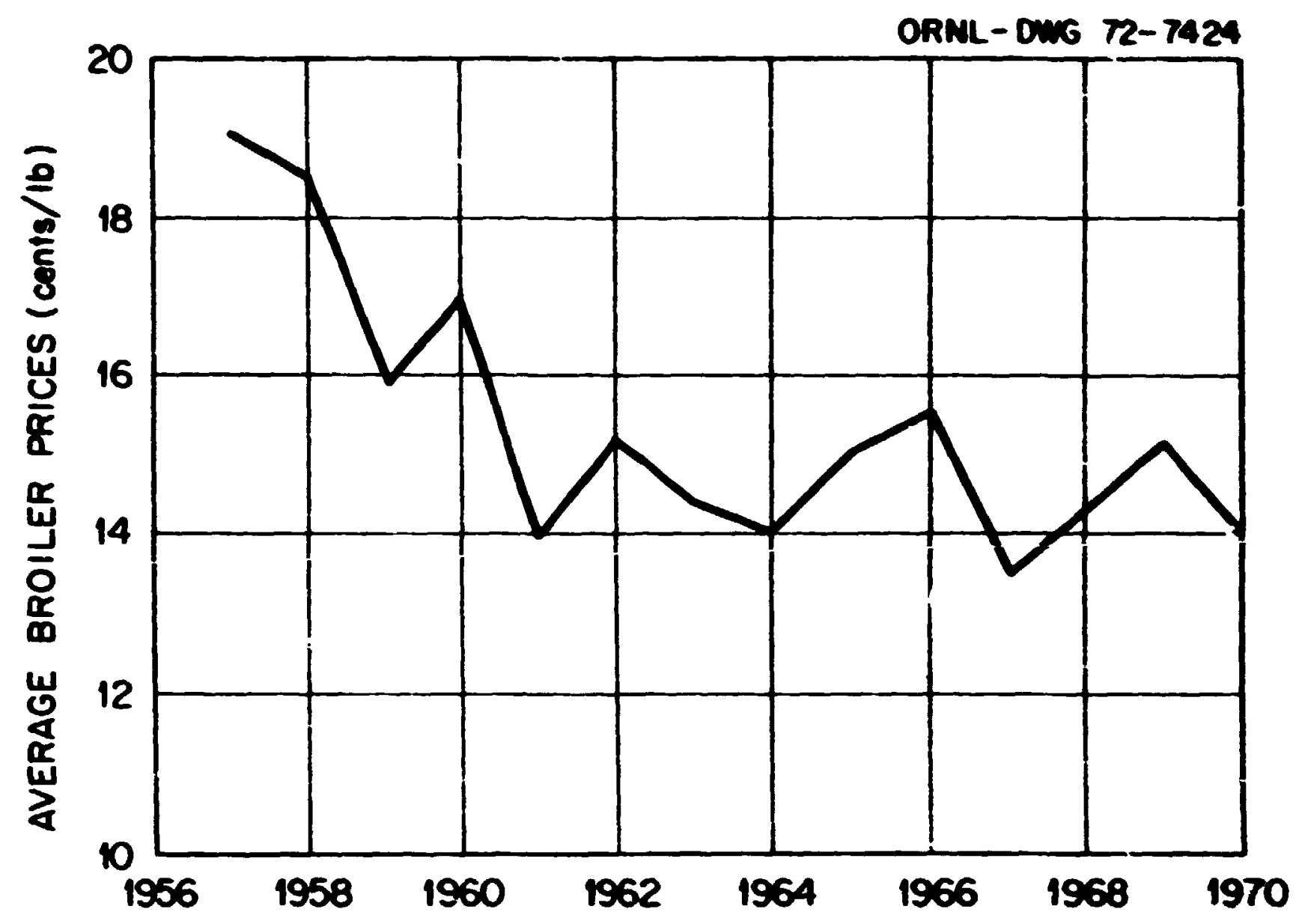

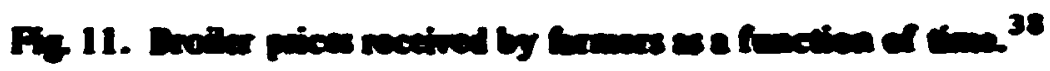

Talle a. US. broiler production" 39 (ISS)

\begin{tabular}{|c|c|c|}
\hline & $10^{\circ} \mathrm{b}$ & $\begin{array}{c}\text { Procent of } \\
\text { totel }\end{array}$ \\
\hline Georyia & 1,548 & 15.4 \\
\hline Artanisies & 1,410 & 14.1 \\
\hline Aloban & 1,235 & 123 \\
\hline North Carolina & 1,038 & 10.3 \\
\hline Misciecoppi & 774 & 7.7 \\
\hline Maryland & 680 & 6.8 \\
\hline Texas & 597 & 5.9 \\
\hline Delaware & 521 & 5.2 \\
\hline Reat of U.S. & 2,243 & 22.3 \\
\hline rota: & 10,046 & 1000 \\
\hline
\end{tabular}

Typical costs to the farmer of producing broilers are tabulated in Table 9, from ref. 40. This :able shows the importance of maintaining high feed efficiency. Feed accounts for $62 \%$ of the total cost of roising broiless. The figures presentel in Table 9 are in good agre ement with more recent USDA figures."

Poultry physiology. The value of a controlled environment for broilers has been recognized for some time. Numerous experiments have been conducted which show that feed efficiency and growth rate can be improved by property adjexing the rempaseture, bumidity, and reatilation within poubry stelvers.

Barott and Pringle" 2-44 demomotrated the inportinace of temperature control for youns chiche. Their copperiments indicate that maximan growth retes cocar when the air temperature starts at $95^{\circ} \mathrm{F}$ on the day of batch and drops comtincousty to 80\% 0 on the 18th day and $65^{\circ} \mathrm{F}$ on the 32 ind dy. Figure 12 stroms the efiect on growth rate of changing air tempereturea.

Teats conducted in Marylandes stowed that maximum growh rate and feed efficieacy occur between 60 and $70^{\circ} \mathrm{F}$ for broiters four weets of ace and obler.

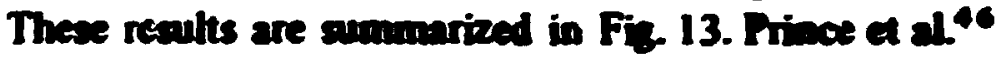
showed that the feed efficiency was $11 \%$ hinter for broilers housed at $65^{\circ} \mathrm{F}$ than for broilers at $45^{\circ} \mathrm{F}$.

Figure 13 shows that increasing the temperature from $40^{\circ}$ to $60^{\circ} \mathrm{F}$ increases broiler gromth rate by 140 and feed efficiency by $11 \%$. This monets that proper temperature control can reduce feed coets (improved feed efficiency) and reduce per unit bebor and capied costs (hicher growth rates).

This shows that broilens grow beat when the tempers. ture is maintained within the appropsite tempereture

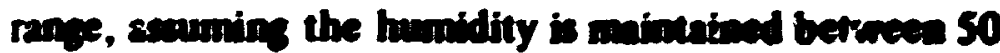
and 70\%.47as Adequate remilation is requibed to remove moingare and odors, and to provide a uniform 
tempera:ure diaribution and adequate oxysen. Ventilation races should be about $1 \mathrm{cfm} / \mathrm{tb}$ in winter and 2 $\mathrm{cfin} / \mathrm{b}$ in summer. ${ }^{30}$

Correat shether enjmearing prectices. A well-insulated house can cut fuei costs by a factor of 4 compared with an uninsubted house. 51.52 Research demonstrated that energy requirements per broiler ranged from 20,000 Det in the summer to almost 60,000 Btu in the vinter with an uninsulated house for a full eight-week period, that is, from birth to market. These figures were redwed to 5000 and 13,000 Btu for an insulated house.

Drury ${ }^{53}$ compared several different kinds (coal, gas, and electric) of brooders. Some were operated in a warm room, the ourpose of which was to maintain comfortable conditions throughout the hosse so the chictens coush keep warm with less feed. In cool-room brooding, only the area near the brooder is kept warm. The temperature in the rest of the house fluctuates with the ambient.

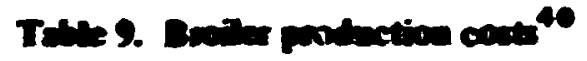

\begin{tabular}{|c|c|c|}
\hline & $\begin{array}{c}\text { Ceata/b } \\
\text { soint }\end{array}$ & $\begin{array}{l}\text { Parcent of } \\
\text { total cost }\end{array}$ \\
\hline 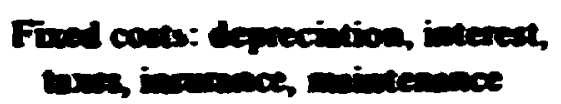 & 1.0 & 5.7 \\
\hline Cides & 3.1 & 176 \\
\hline Foul & 110 & 62.5 \\
\hline Intex & 1.4 & 8.0 \\
\hline & $\begin{array}{l}0.6 \\
0.5\end{array}$ & $\begin{array}{l}3.4 \\
2.8\end{array}$ \\
\hline Tow on & 17.6 cents & 10000 \\
\hline
\end{tabular}

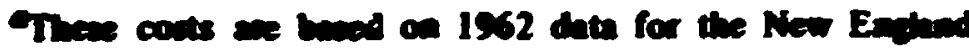

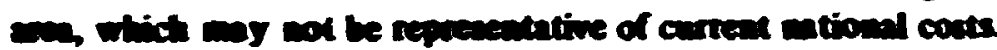

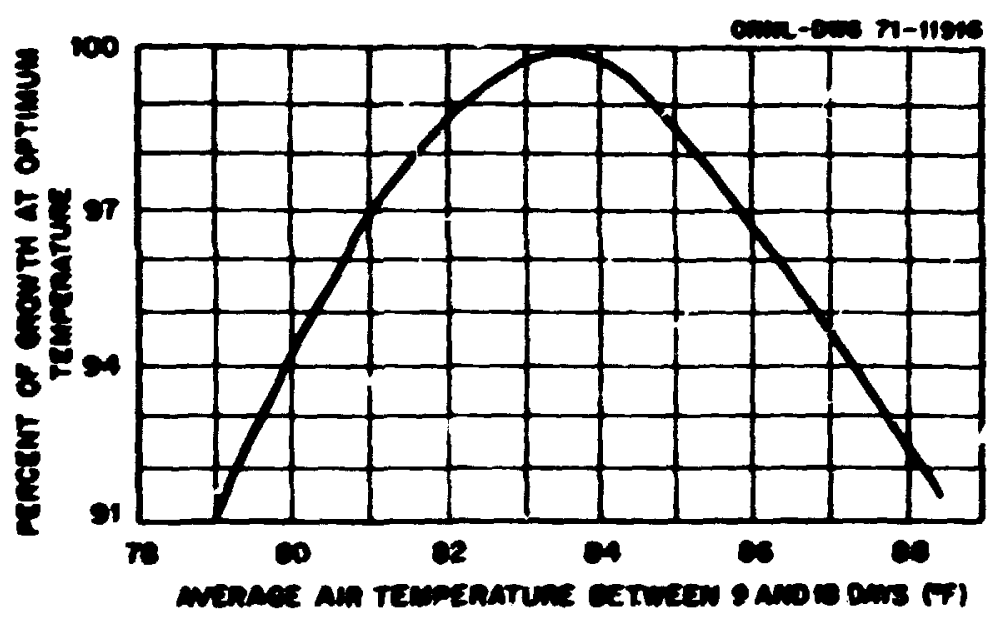

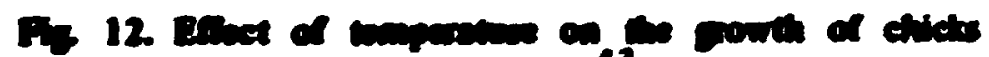

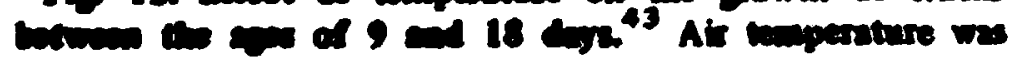
chers 8T F on the gat dy.

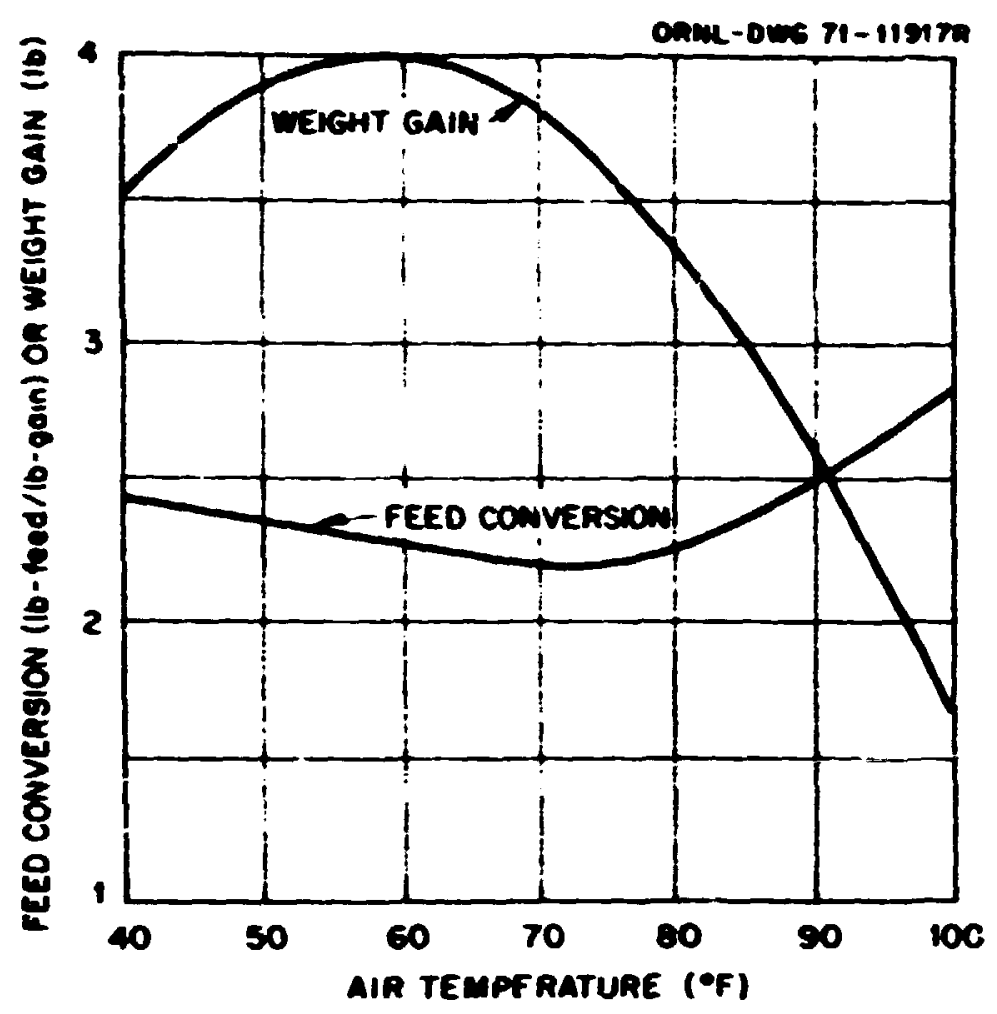

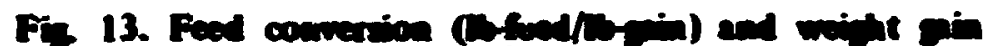

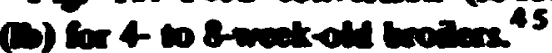

Under winter conditions, costs range from 4 cents/ bird with warm-room coal heaters $(60,000 \mathrm{Btu} / \mathrm{bird})$ to $0.5 \mathrm{cent} / \mathrm{bird}$ with cool-room electric heaters $(7500$ Btu/bird). In surmmer tinese figures are reduced by a factor of 3 to approximately 20,000 Btu/bird with coal and 2500 Btu/bind with electric heating.

The use of evaporative coolers for poultry is still quite controversial. Drury, ${ }^{54}$ in Georgin, expressed doubt that the operating costs of the equipment would be offset by the increased production. On the other hand, Longhouse and Garver s' note that evaporative cooling is successfully used in Texas for broilers, where the wetbulb depressios is 20 to $30^{\circ} \mathrm{F}$ during midday. Otas6 pointed out that evaporative cooling can be used in the Southeast during the warmest part of the day, because then the wetbulb depression is greatest. In almost all cases, drybulb temperatures above $80^{\circ} \mathrm{F}$ occur with wetbulb temperatures below $60^{\circ} \mathrm{F} .^{47}$, Table 10, from ref. 47 , shows the inside conditions to be expected with evaporative cooling. If the inside humidity is to be maintained below $80 \%$ (a reasonable upper limit), then the outside relative humidity must be lower than $50 \%$ in order for evaporative cooling to be effective.

Current design recommendations for broilers include proper ventilation, adequate insulation, and the use of

The decin wetbulis temparature is mailly hister, around $75^{2} \mathrm{~F}$. 


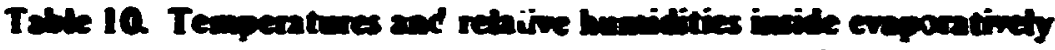

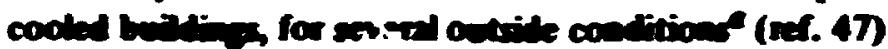

\begin{tabular}{|c|c|c|c|c|c|c|c|c|c|c|c|c|}
\hline \multirow{3}{*}{$\begin{array}{l}\text { Relative } \\
\text { mamidity of } \\
\text { outside ai. } \\
\text { (\$ RH) }\end{array}$} & \multicolumn{12}{|c|}{ Drybues temperature of outside air $\left({ }^{\circ} \mathrm{F}\right)$} \\
\hline & \multicolumn{3}{|c|}{85} & \multicolumn{3}{|c|}{90} & \multicolumn{3}{|c|}{95} & \multicolumn{3}{|c|}{100} \\
\hline & $\mathbf{T b}$ & Te & RHc & $\mathbf{T b}$ & Tc & RHc & $\mathbf{T b}$ & TC & RHe & $\mathbf{T O}$ & Te & RHC \\
\hline 20 & 65 & 68 & 72 & 68 & 71 & 73 & 72 & 75 & 70 & 75 & $\boldsymbol{7 8}$ & 71 \\
\hline 30 & 68 & 71 & 75 & 72 & 75 & 75 & 76 & 79 & 73 & 80 & 83 & 73 \\
\hline 40 & 71 & 74 & 79 & 75 & 78 & 79 & 79 & 82 & 78 & 83 & 86 & $\boldsymbol{n}$ \\
\hline so & 74 & 77 & 82 & $\boldsymbol{r}$ & 81 & 82 & 82 & 85 & 82 & 87 & 90 & 81 \\
\hline 60 & 76 & 79 & 86 & 81 & 84 & 8 & 85 & 8 & 8 & so & 93 & 85 \\
\hline 70 & 79 & 82 & 87 & 83 & 86 & 87 & 8 & 91 & 90 & & & \\
\hline
\end{tabular}

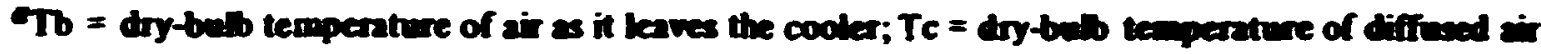

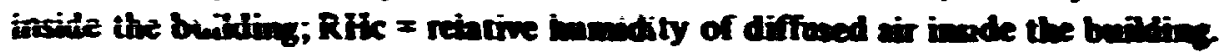

brooders for young chicks. Installed brooder capacity ranges from 15 to 30 Btw/hrbird, depending on insulation and geographic and climatic conditions. Summer cooling is usually accomplished with increased ventilation rates, although evaporative cooling is used in some locations.

\section{Swire Operations}

Hog production has remained fairly constant over the past several years, increasing only slightly from 96 million in 1955 to 102 million in $1970 .^{38}$ Hog prices received by farmers have varied erratically over the past is years, as shown in Fig. 14, ref. 57; however, the trend seems to be toward an increase in ros prices.

Table 11 lists the eight leading hos-producing states. $^{38}$ Hog production is very concentrated; $70 \%$ of the hogs produced come from the eight midwestern states listed in Table 11 . Production is concentrated in thexe states because of the availability of inexpensive feed, primarily midwestern corn.

Currently, a large toz operation produces about 5000 piza/year. In the past, hoz have been grown in two annual shifts - a spring and a fall crop. Recently, the trend has been to year-round griwing to make better use of the farrowing houses.

Economic data concerning hog production is quite scanty. Table 12, based on information in refs. 59 and 60, shows that feed accounts for $65 \%$ of the costs in raising hogs. Fuel accounts for about $4 \%$ of this cost.

Swive physiolosy. Heitman, Kelly, and Bond'1 studied the infuence of ambient air temperature on the growth rate of swine; see fig. 15. The optimum temperature for hos varies from $73^{\circ} \mathrm{F}$ for $100-\mathrm{B} \mathrm{pir}$ to $65^{\circ} \mathrm{F}$ for 250 tb pizs. The growth rate drops of sharply on either side of the optimum temperature a:d

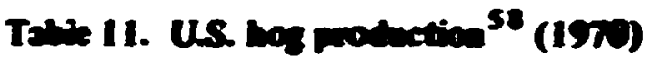

\begin{tabular}{|c|c|c|}
\hline & $10^{3}$ bad on ind 12/1/70 & Perceant of wat \\
\hline lowe & 16,322 & 24.2 \\
\hline Inimois & 7,468 & 110 \\
\hline Intion & 5,129 & 7.6 \\
\hline Misori & 5.120 & 76 \\
\hline Minosola & 3,692 & 5.5 \\
\hline Nebeatea & 3,691 & 5.5 \\
\hline Otio & 2.838 & 4.2 \\
\hline Kones & 2,202 & 3.3 \\
\hline Rest of U.S. & 21,078 & 31.1 \\
\hline Toes & ii7,540 & 1000 \\
\hline
\end{tabular}

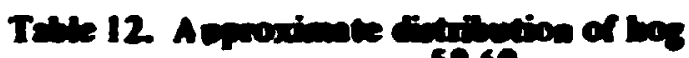
podicetion conts9.60

\begin{tabular}{|c|c|c|}
\hline & $\begin{array}{c}\text { Doluns/hos } \\
\text { sold }\end{array}$ & $\begin{array}{l}\text { Procent of } \\
\text { tootel cont }\end{array}$ \\
\hline 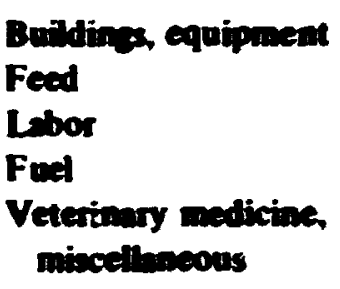 & $\begin{array}{r}\$ 3.60 \\
13.00 \\
1.60 \\
0.00 \\
1.00\end{array}$ & $\begin{array}{r}18 \\
65 \\
8 \\
4 \\
5\end{array}$ \\
\hline Total cost & $\$ 20.00$ & 100 \\
\hline
\end{tabular}

even becomes negative at hich temperatures. For example, sbove $95^{\circ} \mathrm{F}$ larer pis begin to lose weint. This occurs because of depreased appetites and in creased respiration. The growth rme of a $200 \mathrm{~s}$ pis decreases by $33 \%$ if the temperature is more than $13^{\circ} \mathrm{F}$ higher or lower than the optimum $\left(69^{\circ} \mathrm{F}\right)$.

Warwick, ${ }^{62}$ Sorensen, ${ }^{63}$ and Manpold et al."4 preant results which confirm Hejo man's data and show that the 


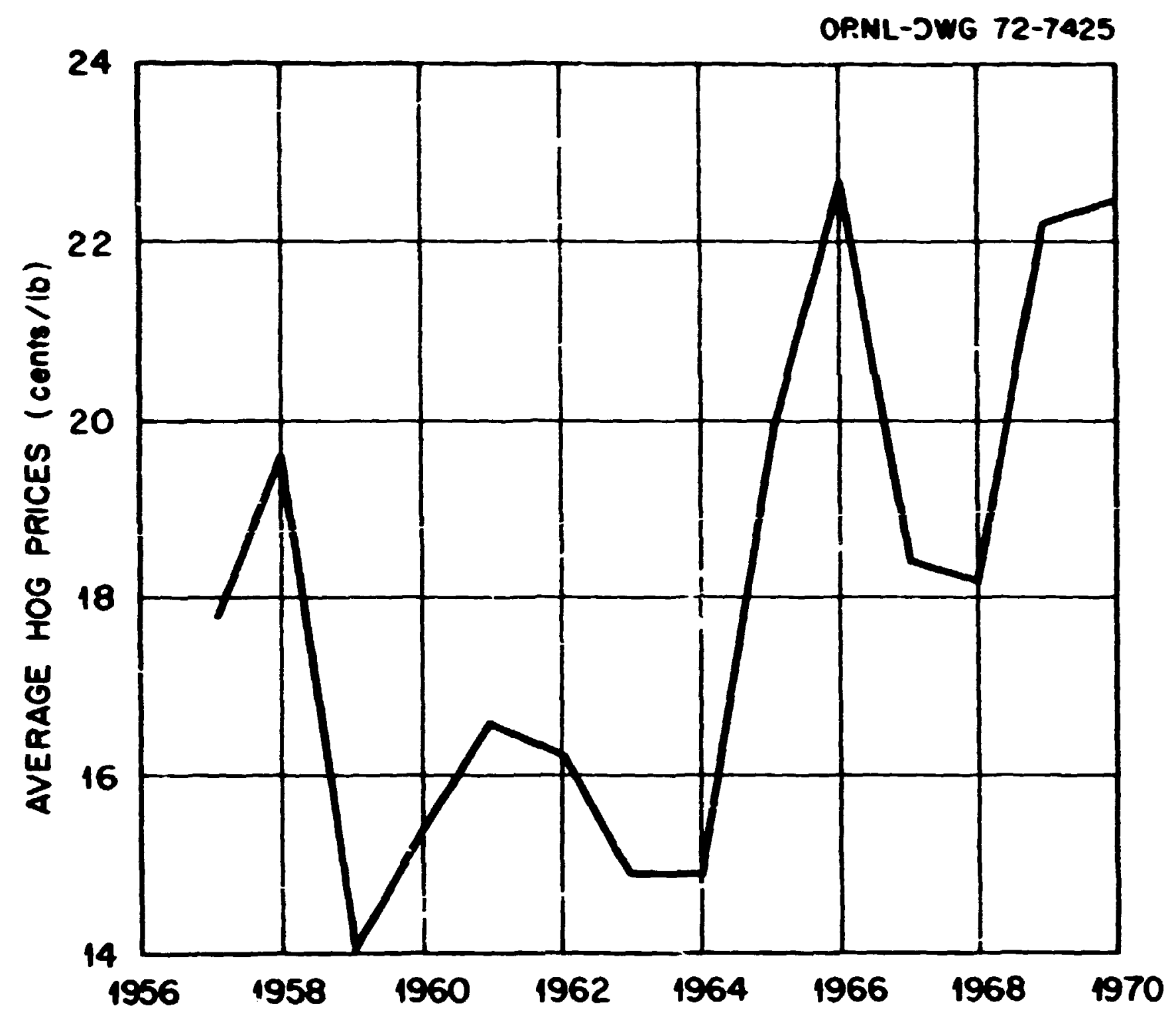

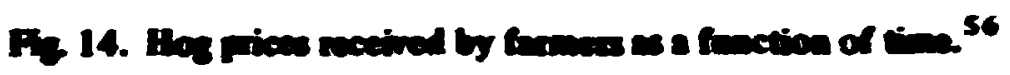

temperatures for optimum feed efficiency are nearly identical to the temperatures for maximum growth rate. These results are well summarized in Figs. 16 and 17, from Dale."s Figure 16 shows that the optimum temperature for feed efficiency decreases with it creasing hog weight, in agreement with the data shown in Fiz. 15 for daily weight gain.

Figure 17 shows how temperature influences the time 10 market a $240-1 b$ pie. As the daily weight gain inca...:-, the time required decreases. Both the total feed consumption and the time required are a minimum between 60 and $70^{\circ} \%$.

The effect of humidity un swine was investizated by Morrion $A$ al. " In general, both feed efficiency and weight gin decrease with increasing humidity. Weight vini drops approximately $0.1 \mathrm{Bb} / \mathrm{day}(\sim 5 \%)$ with an increase in humidity from 45\% to 95\%. Despite the adverse effects of hiph humidity, the authors conchude that "evaporative cocline of hot dry air at the expense of increasing the inumidity is desirable, since the benefit of lower air temperature would molic than offset the possibly small detrimental effect of the higher humidity."

For example, evaporative cooling of ambient air from $90^{\circ} \mathrm{F}$ and $30 \% \mathrm{RH}$ to $74^{\circ} \mathrm{F}$ and $70 \% \mathrm{RH}$ will increase daily wight gin almost $60 \%$. Thus, evaporative cooling would ixcrease weight gain by mo.e than $0.5 \mathrm{lb} / \mathrm{day}$ under these conditions."

The optimum temperature range for piss is between 60 and $70^{\circ} \mathrm{F}$, and the relative humidity should be maintained betweel, $50 \%$ and 75\%.97.68 Ventilation rates vary from 50 : $\mathrm{fm}$ for a scw and litter, and $20 \mathrm{cfm}$ for a finishing hog in winter, $10200 \mathrm{cfm}$ for a sow and litter, and $100 \mathrm{cfm}$ for a finishing hog in summer."s9

Current streter exdneerius practices. Traditionally. environmental control in hog hurses has been limited to ventilation and insulation. Several USDA publications"9-71 on swine shetters were iscured in the late 1950's and make no mention of supplemental d eating or cooling for noninfant swine. Infrared brooder s were 


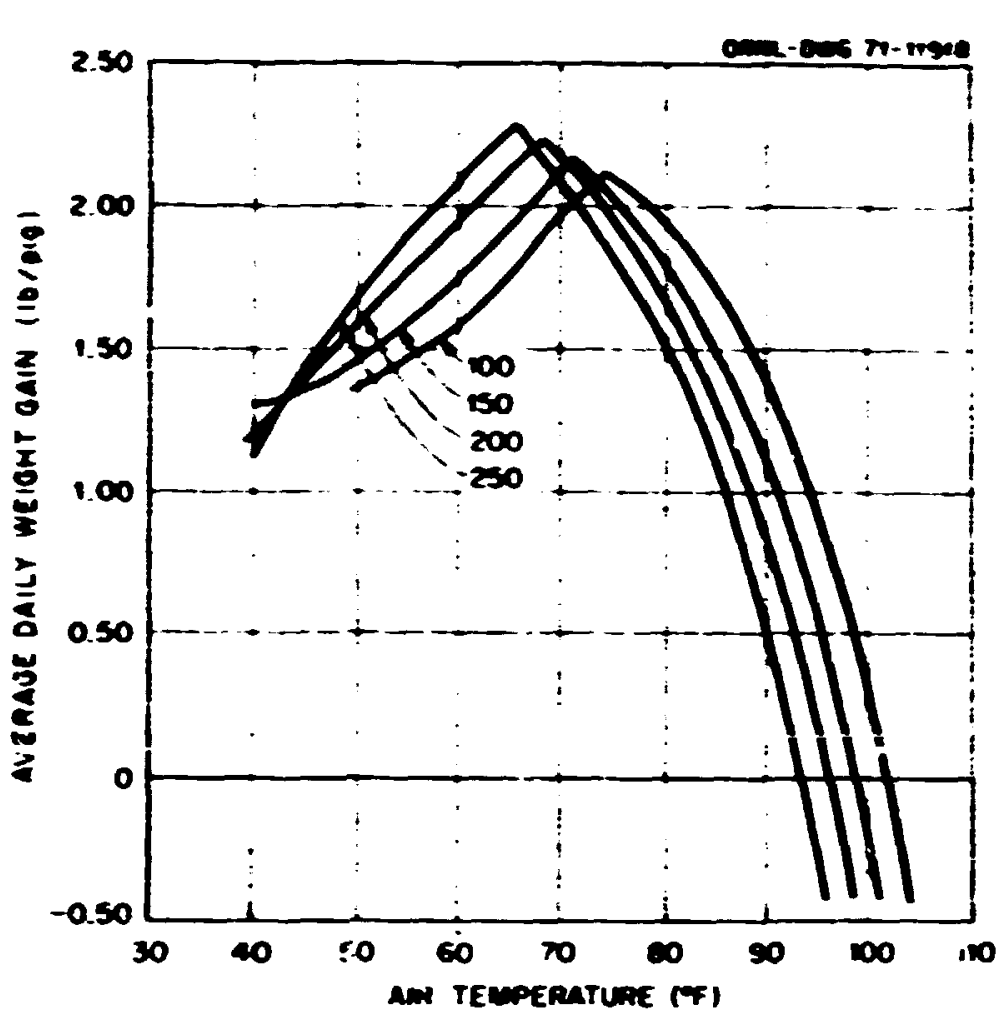

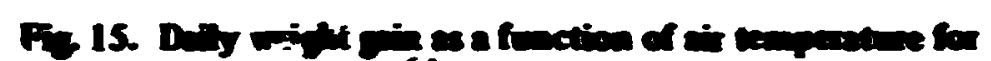

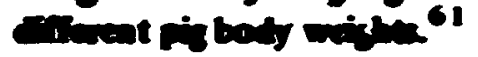

recommended for warming baby pisa and shades and wallows were sumesed for cootim pios in sumber.

More recentiy, supplementai iating nes been reconmended for all swine in winters" to improve weight gain and feed efficiency. Heater caparities of 2000 to $5000 \mathrm{Bru} / \mathrm{hr}$ for a sow and litter. and 100 to $500 \mathrm{Bru} / \mathrm{hr}$ for a finishing swire are surested."s9

Experiments r.rfonsed in Sorth iarolime'2 using electrical strip heaters showed a: astree (besed on a year's operation) supriemental heating requirememt of $1400 \mathrm{Bru} / \mathrm{hi}$ for a som and litter confined in the heated pens for 21 days.

Shades, wallows, sprinklers, and drinkine water offer considereble retief from high temperatures for swine. ${ }^{13-74}$ Garrett at al's compared the effects of mechanical air conditioning with those of a staxed water wallow on hog performance. Whic feed efficiency and growth rzte were inproved with air conditioning, air conditioning is generally uneconomical; that is, the capital and operation cosss of air conditionios exceed the value of increased weight gain. However, mechanical air con itioning is ueful for spot cooling of Lectating soms. ${ }^{76}$ Cooling only the 800 , rather than the entire building, reduces the recalired capacity by a factor of 10 .

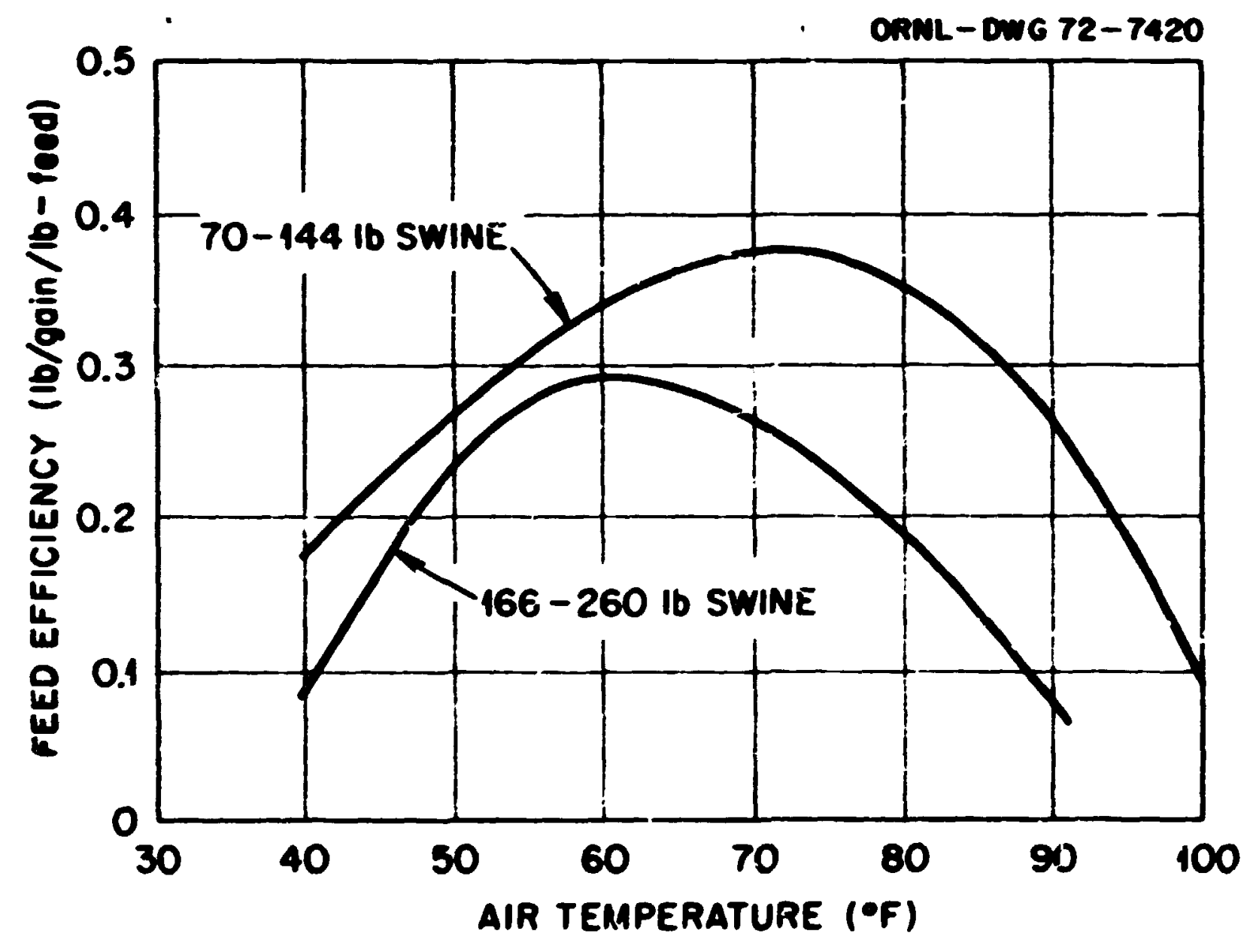

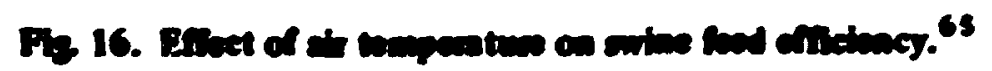




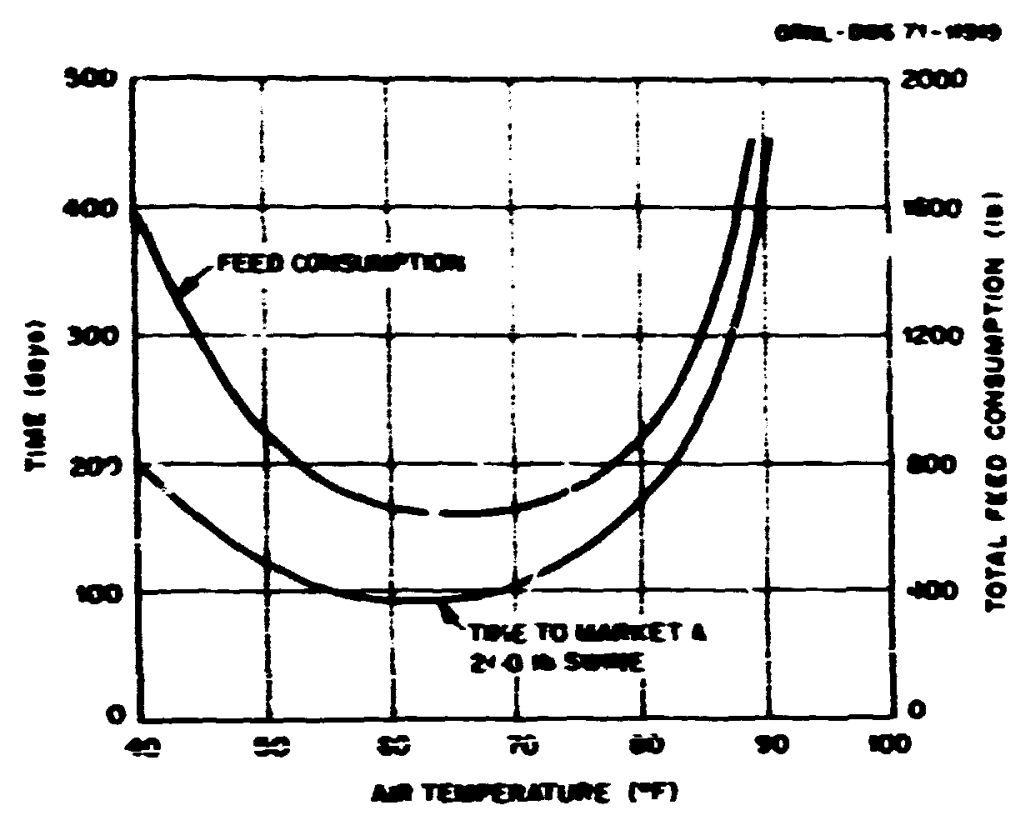

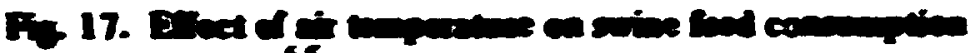

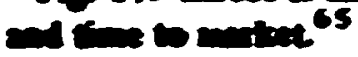

Howea and Mangoldse supat that evaporative coolers are usefui ondy in arid rejoas. Where the wetbelb deprevion is sidht, evaporative cocting may crea be defimental, becme hos cool themsetves in warm weather by iecreacing evaporation through hider rexpiration mates. If the bumidity is incresed, then lung repiration is les effertive. These conctseions, however, confict with the reaults obtained by Morrivon et a.66.6?

Thus, curreat trends in hos production are townd greater exvirowmental control. Specifically, some form of supplemental heating (under-floor or hot air) is becoming increasing prevalent for both farrowing and finiding operations. Protection from thermal stress in the summer is normally obtained by high rentilation rates, proper inalation, and drinking water. Neither mechanical air conditioning nor evaporative cooling appears to be widely used.

\section{Potemial Reweits of Wacte Heat Utimtion}

It is of interest to compute the fraction of waste heat produced by steam-lectric power pionts which can profitably be used for temperature control of swine and poultry shelters.

Approximately three billion broilers were grown in the U.S. in $1970 .^{38}$ Since broilers are frown yearround, the average energy required to brood all these chicks can be taken as 10,000 Btu/chick for a wellinsulated house. 31 Thus approximately $0.3 \times 10^{14}$ Btu/year are required to brood all the broilers currently grown in the US., using current data. With low-cost waste heat available from power plants, heat use might be hister since the ecomomic peralty of providing optimin' thenal confitions would be geatly rechuced.

Jimeson and Adrins" atimate that $5.3 \times 10^{15}$ Bidyea of wate hex was rejected from power generation station in 1970 . Thus, sbout $1 \%$ of the total waste teat gonated could be 5 aed for raining broifers - under curren conditions if all the broilers were raiced uniag waxe hex from power stations. In the winter, broile heating could use almost $2 \%$ of the waste heat dischanged, but in the summer it could use only $0.5 \%$ of this beat.

Hazes 78 extimates that 5000 Btw/hr are dacirble for a sow and litter during a typic. ' Iown winter. This heat wheld be for the aquivient of 50 days at the bove rate. Asmming 5 milion litters/winter implies that $3 \times 10^{13}$ Btu would be required for heating all the sows and litters produced in winter. This compares quite well with $0.7 \times 10^{13}$ Btu suzested by data obtained in the much warmer chimate of South Caro $\lim ^{72}$

In addition, approximately $300 \mathrm{Btu} / \mathrm{hr}$ are required for finishing pise. Using the same 50-day full we factor and 50 milion piss per winter gives $1.8 \times 10^{13} \mathrm{Btu}$ required for the fiviothing operation in winter.

Thus, about $5 \times 10^{13} \mathrm{Btu} /$ winter are required to supply the current winter heating needs of American hos production. This is $1 \%$ of the total waste heat generated and about $3 \%$ of the winter heat generated. During the ammer, very little waste heat would be required, just enough to keep the litters warm at night. The thermal requirements of hos production are slightby greater than those of broiler production. However, broiler heat requirements are not so concentrated in the vinter.

The use of waste heat san reduce fuel bills and increase feed efficiency and growth rate for both iogs and broilers by previding optimal temperature conditions. A pad and fan system, in conjunction with a finned-tube coil (system describer? later), can provide both winter heating and summer cooling while, at the same time, cooling the condenser water.

Ii heating costs $\$ 1 /$ million Btu, then the maximum potential saving for broiler and hog growers are about $\$ 3 \mathrm{million} / \mathrm{year}$ (\$0.01/broiler) and $\$ 5 \mathrm{million} /$ year (S1/hog) respectively. This assumes that 10\% of American broilers and hog are grown using free waste heat, before incremental costs are subtracted. Altermate computations of the fuel saving using data fromis iefs. 40,41 , and 60 give figures in reasonable zgreement with those above.

Thus, the use of waste heat for warming arimal shelters might save poultry and swine operators $\$ 8$ 
million/year in fuet costs based on carrent fuet consumption finures. However, since current practice does not maintain optimal temperatures, the potential sovings may be higher than indicated here because of improved feed efficiency and increased growth rates. Feed accounts for over $60 \%$ of the total cost in both broiler and swine operations. ${ }^{40.41} .59$

For example, ref. 45 shows that increasing the ambient temperature from $60^{\circ}$ to $70^{\circ} \mathrm{F}$ increases the feed efficiency for broilers by at least $0.05 \mathrm{~B}$-feed/lbgain. With feed at $50.05 / \mathrm{b}$ (and production of 11 billion pounds of broilers annually) this represents a sevings of $\$ 2.7$ millioniyear (\$0.0075/broiler) when applied to $10 \%$ of broiler production.

Similarly, increasing the air temperature from $60^{\circ}$ to $65^{\circ} \mathrm{F}$ for swine reduces the total feed consumed by 20 b/hog, ${ }^{65}$ see Fig. 17. This represents a savings of $\$ 7$ million/year (\$0.70/hog) with feed at $\$ 0.035 / \mathrm{tb}$ and production of 100 million hos anmually, Again, a 10\% appiication factor is used. Thus, even stight changes in ambient temperature can significantly reduce feed costs.

\section{The Eraporative Fad and Fan System}

The system envisioned for heating and cooling animal shelters involves the use of conventional pad and fan systems with finned-tube coils; see fig. 7 and the discussion on greenhouses in this report. Pad and fan systems are currently used in many greenhouses and in some poultry and swine operations for cooling purposes. The pad and finned-tube system uied in the ORNL experimental greenhouse is shown in Figs. 6 and 8.

The pads (see Fig. 5) are typically filled with a semipermanent fibrous material. Condenser cooling water flows onto the pads from a trough at the top and drips vertically down along the fibers. Air flows horizontally across the pads and is heated or cooled depending or the ratio of sensible to latent heat transfer. The cooled water is collected at the bottom of the pads and in a closed system would be pumped back to the condensers.

Warm water from the condenser may also be pumped through the finred-tube coils, located downstream of the pads.* The air coming from the pads is heated and dried by the transfer of sensible heat across the fins. By varying the relative fractions of water pumped through the pads and the coils and the air flow rate, the

\footnotetext{
*Altemately, the warm water could be run through pipes embedded in the floor of the shelter.
}

temperature and humidity of the air entering the animal sheter can be adjusted oner wide ranges. This system can be used for toth summer cooling and winter heatine. The heated (or cooled) air pesses throingh the house and out .he other end through exhanst fans. Automatically controlled louvers mould permit recircobtion under conditions of extreme cold.

With this system the exvironment within the animed sheter can be maintained near the optimum. Simaltaneously, the power ptant condenser water is coolad, approaching the ambient wetbulb temperature. Thes, the animal shelter serves as a horizontal cooling tower. The engineering detaik of thix system are descrited ty Beall and Samuets. ${ }^{3:}$

\section{Indivens}

A significant obstacte to the use of waste heat for animal shelters is insufficiem knowled fe. Funter studies are needed to determine the techniol and economic feasiolity and desirbility of such a syatim

Using inien: lizures, broiler houses and swine thet ters could ux about $2 \%$ of the total waste hen: generated at steam-lectrix power plants if all prowent animak were raised using such heat. The generation of electricity has been doubling every ten years for the past several decades and will probobly contivuce to do so for some time. The growth rate in swine production is considerably lower, only a few percent per decade. Broiler production has increased rapidly, about $80 \%$ during the past decade. However, this gromth rate is also sower than the growth in electrical generation. Thus, it appears that in the future, animal shelters will require an even smaller fraction of the waste heat generated - assuming current trends continue.

Geographic concentration is another factor which may inhibit the use oi waste heat for animal shetters. Hog production is very concentrated in the Midwest, and broiler production is concentrated in the Southeas. Power plants in these areas may be able to couple their operations with agricultural enterprises, but throughout most of the country, broiler and swine production are so low that they will be unable to use more than a small fraction of the power plant waste heat. However, it is possible that the lure of cheap (even free) .eat may induce broiler and swine production to shift geographically. For example, New York produces only $0.1 \%$ of American broilers ${ }^{39}$ but probably consumes 5-10\% of the total production. If the use of waste heat can lower production costs sufficiently, New York may be able to grow its own broilers.

In osder to minimize pumping and piping costs, the broiler and swine operations would have to be located 
adjacent to the power Dlant (whthin its exclusiois area for a nuckeat plant). The waste heat from a (500-1MMe) plant is sufficient to brucis almost one billi in broiters a yeat or farrow and finish abolit 10 million hozs a year. As indicaled eartier. a !ypical broiler operation cur. rent:y produces about $\$ 0.000$ tirds annually, and a lange hog operation produces aboult 5000 pia/year. Thus. current operations are nov ai threc orders of magaimule smolk then would be riequired to use $10 \%$ of the waste heat from a modern power plant.

Several problems may arise with large operations such as discase. codur. and waste disposal. a: d these have not yet been resolved. In panicular, wasie disposal may be a major problem with hoe operations. Curient legishation and regulations require improved waste itiatment, and the resultirg cconomic penalty may inhibit the development of larget operativers. However. future technological devetopiments may elirainal: this problem.

Simailarly, tog operiaions rejpuire a considerable amouni of land. Mazen" estimates that a 1000-hog operation requires about 30 a cres. This inclucies hos housing. feed storeye, and waste disposal facilities for a controlled environment uperation. Linear extrapolation indicates that 30,000 acies would be required to produce a million hoo/year lenough hos to use $10 \%$ of the wasse heat from a typical $1000-\mathrm{MW}(\mathrm{e})$ plane).

The capual coass of the pad and fan and finnertiube coil system plus the pumps and piping are higher th' n the costs of conventional brooders and space heaters. These additional capital costs must be compared with the reduction in operating costs due to the use of waste heat. In many locations (e\&., the South) the additional capital expenues may not be justified.

The demands for beat in animal shetters are quite seasonal - considerebly higher in the winter than in the summer. Yet it is during the warm summer months that thermai pollution problems are most severe. In the summer the animal shelter would serve as a horizonial cocling tower, with littke advantage to the farmer. Ia fasl, the high humidities and temperatures aseociated with this operation may be detrimental in certain regions of the country whete the wetbulb depreasion is small.

Variations in electrical generation may seriously hamper the use of waste heat for heatise animal chelters. If the power plant shuts doon fos a lorg time during a period when teat is required. alternate neans mus be provided for warming the chicks or pis. The cost of inatalling a backup heating system must he compared with the savings from the use oi waste heat. This would not be a problem at multiunit prewer plants.

Biocides and other toxic substances are usually added to condenser cooling water to prevent the growth of algae within the condenser tubes and accessory piping. Carry-over from the evaporative pods may be harniful to poultry and swine.

Durine the winter, when air is heing recirculated within the animal shelters. high dust kevels may accumulate on the pads and in the cooling water. This dus. buildup may block airflow, reducing heat transfer. and may ako change the chemical quslity of the cooling water sufficientily to agravate corrosion problems.

The condenser cooling water circulatiad through the pads in the animal shetter is cooled hageiy by evaporation. This represents a consumptive use oí water, amountine to about $2 \%$ of the total flow rate. In aria regjons this water loss may be unacceptable. However, the water loseses are no higher than they would be wit", an evaporative cooling tower.

Climatic variability is another factor which may inhibit the use of waste heat in animal shetters. Only certain regions of the country have ctimatic conditions suitable for the use of waste hen. The Midwest is a good candidate for waste hear applications, because the winters are cold and the summers are cool, with reasonable wet-bulb depressions. The Southeast, on the other hund, has varmer winters and a very small wet-bulb deprescion. So heai utilization will probably be minimal in the Southeast.

Concem about radioactivity may make people retuctant to buy pork and broilers grown in a reactor exclusion area. This problem can probably be overcome with a suitable public education program.

Figures 11 and 14 stow the annual average prices for broilers and hogs over the past 13 years. Broiler prices have steadily deciined, while hog prices have increased erratically. These fluctuations in the average -rices show that broiler and swise operatione are somewhat risky. This riats and the low retum on investment may hamper the expansion of these operations into areas of waste heat utilization.

\section{Conctuaion}

The use of raste heat for environmeitial control of animal shelters has the potential for reducing costs and minimizing environmental impacts at certain locations. Potential fuel savines are about 58 million/year for the industry, and the potential reduction in fred costs are in the same range. However, various problems exist which might inhibit auch user. Studies are needed to determine the technical, economic, and environmental desirability of such a system. Research is nreded in several areas to beicer define the problems and potential aeociated with waste heat utilization in animal shelters. 
Technical questions concerning the actual performance of pad. fan. and finned-tube systems remain. Preliminary work at ORNL suggests that this system can provide adequate environmental control in inany parts of the country. but applirations to ecmriercial operations must be demonstrated.

The problems associated with economics and management have not yet been addressed. Research is needed to answer the following questions: Can feed efficiencies be further increased or are curreat practices nearly optimal? What are the problems associated with very large hroiler and swine operations? Are such large operatio.s economically viable? Are the savings in fuel costs worth the additional capita! expenses associated with pumps and piping? How should the capital costs be appontioneri between the utility and the farmer? Will cheap heat reduce the riskiness of these farm operations?

if research suggests that such systems for animal culture are feasible and desirabk; then a pilot-plant progrem should be initiated to obtain field data. Ideally, the field trial should inciude greenhouse, poultry, and swine operations. In preliminary trials the size of the operation should be kept small, but in later tests these operations should be significantly increased to about 50 acres of greenhouses, 500,000 broilers/ year, and 50,000 hogs/yea: to teveal the problems coused by larger agricultural operations.

\section{Summary}

Agricultural operaticns are capable of using lowtemperature (waste) heat from powtr plants without reduicing electrical energy production. While these uses will net solve the thermal pollution problem. they an, in particular locations, reduce the impact of thermal effluents on the iocal ecology, conserve energy resovices, and save money for both the electric utility and the farmer.

Thermal effluents from power plant. can be used in open-field-agriculture to piomote rapid plant growth, improve crop quality, control pests and disease, extend the growing season, and prevent damage due to temperature extremes. Water, used for both irrigation and heating, can be applied through nozzles (spray irrigation) of through a subsurface piping system. With these systems the farni acts as a large, direct-contact heat exchanger for the power plant, while the utility provides irrigation water to the farmer.

Several research projects are under way in the Pacific Northwest to investigate the feasibility and desirability of these systems. Some additional work is beirs performed in the Southeast.

This use of heat is of importance for only a few days of the year (early spring and late fall). During the remainder of the year, water is needed for irrigation but not for heating. However, most power plants are sited near urban centers where rainfall is sufficient to obviate the need for irrigation. Also, the long-term implications of waste heat applications for soil management and disease and pest control are nor yet known.

The use of porver plant waste heat for warming and cooling greenhouses can impreve crop growth and yield while reducing operating (fuel) costs by as much as $\$ 4000$ to $\$ 6000 / a c r e$. With approximately 7090 acies of greeniouse production today, this represents a ictal potential saving in fuel costs of $\$ 28$ to $\$ 42$ million annually on a national basis (10 to $30 \%$ of operating costs).

Research at the University of Arizona, University of Sonora, and the Oak Ridge National Laboratory sug gests that using waste heat for greenhouse climate control is both feasible and economically attractive. However, no large-scale field operations are currently under way.

Waste heat can be used to provide optimal temperture control in swine and broiler houses. Fuel costs could be reduced by $\$ 8$ million annually on a national Dasis. Additional savings in feed costs may result from improved feed efficiency under controlled environmental conditions.

Additional study is required to determine the limittions imposed on agricultural uses by climate, raphy, product marketing, waste heat reliability, effects of biocides and corrosion inhibitors in the coolin water, and consumer acceptance of products grown using cooling water from nuclear plants.

It is essential that these problem areas be thoroughly investigated before a commitment is made to large-scale agricultural applications of waste heat.

\section{References}

1. A. J. Miller et al., Use of Steam-Electric Power Plants to Provide Thermal Eneryy to UJban Areas, ORNL-HUD-14 (1971).

2. F. C. Raney and Y. Mihara, "Water and Soil Temperature," Imigation of Agricultural Lands, ed. by Hagan, Haise, and Edminister, Agron. No. 11, Chap. 53, 1967.

3. F. K. Neilsen an" E.C. Humphries, "Soil Temperature and Plant Growi.1," Soils and Fentilizer 29, 1-? (1966). 
4. A. H. Bunting and P. M. Cartwright, "Agronomical Aspects of Environmental Control," in Control of the Pint Emironment. ed. by J. P. Hudson, Butterworths, London, 1957.

5. B. S. Meyer and D. B. Anderson, Plant Physiolozy. Van Nostrand, Princeton, N.J., 1952.

6. J. F. Cline, M. A. Wolf, and F. P. Hungate, "Evaporative Cooling of Heated Irrigation Water by Sprinkler Applications," Battelle Memorial Institute, Pacific Northwest Laboratory, Richland, Washington, Whter Resources Research 5(2). 401-6 (April 1969).

7. S. J. Riclards, R. M. Hagan, and T. M. MoCalla, "Soil Temperature and Plant Growth," Soil Physical Conditions and Plant Growth, ed. by Byron T. Shaw, Agron. Vol. 2, Chap. 5, pp. 303-480, Academic Press, New York, 1952.

8. William Ehrler and Leon Bernstein, "Effects of Ront Temperature, Mineral Nurrition, and Salinity on the Growth and Composition of Rice," US. Salinity Lboratory. Riverside, California, Botanical Gazette 120, 67-74 (December 1958).

9. K. F. Neilsen, R. ?.. Halstead, A. J. MacLean, S. J. Bourget, and R. M. Holmes, "The linfluence of Soil Temperature on the Growth and Mineral Composition of Corn, Bromerrass and Potatoes," Soil Research Institute, Research Brancin, Canada Department of Agriculture, Ot1awa, Ontario, Soil Science Soc Amer. Proc. 25, 369-72 (1961).

10. L Boersma, "Wam Water Utilization," Department of Soils, Oregon State University, Proceedings of the Conference on Beneficial Uses of Thermal Discharges, sponsored by the New York Staie Department of Environmental Comservation, Albany, New York, September 17-18, 1970.

11. A. R. Magenti, "Hot Water Treatment of Hop Rhizomes for Nematode Control," Experiment Station, Department of Nematolozy, University of California, Davis, Colifomia Agriculture 16,(10), 11-12 (October 1962).

12. P. R. Stout, personal communication, July 3, 1969.

13. H. J. Mederski, principal investigatcr, Ohio Agricultural Research and Development Center, Wooster (research in progress).

14. L. Boersma, H. J. Mack, and W. Calhown, Jr., Inveatipators, Oregon State University, Corvallis (research in progress).

15. Idaho Nudear Energy Cornmiscion, Transactions of the Thermal Effluent Information Meeting, Boise, 82 puges, July 9, 1970.

16. Byron Price, 1971, "Thermal Water Demoistration Project," is Proceedings of the National Con- ference on Wast' iteat Utilization. Fatlinburg. Tennessee, Oct. 27 -29, 1971, ( ONF-711031.

17. R. W. Johns, R. J. Folwell. R. T. Dailey, and M. E. Wirth, “Agricultural Aternatives for Utilizing OtfPeak Electrical Energy and Cooling Water," Agricultural Research Center. Wastington State University. September 1971.

18. J. A. Havens, personal communication, Department of Chemical Engintering. University of Arkansas, Fayetteville, February 1971.

19. R. W. Skaggs, Fersonal communication. Depariment of Biological and Agricultural Engineering, School of Agriculture and :ife Sciences, North Carolina State University, Raleigh, March 19, 1971.

20. Raphael J. Moses, "Legal Problems in Waste Heat Utilization in Appropriatic n States," in Proceedings of the National Conference on Waste Heat Urilization, Gatlinburg, Tennessee, October 27-29, 1971, CONF-71!031.

21. L. J. Carter, "Warm-Water Irrigtion: An Answer to Thermal Pollution?" Science 165, 478-80 (August 1, 1969).

22. Environmental Research Laboratory, The University of Arizona, "The Development of a System for the Production of Power, Water, and Food in Coastal Desert Areas and the Development of a Large Scale Controlled-Environment Research Facility ior Agricidivral Production," Progress Report to the Rockefellei Foundation, May 1970.

23. S. E. Beall, Jr., "Agricultural and Urban Uses cf Low-Temperature Heat," Proceedings of the Conference on Beneficial Uses of Thermal Disctuanges, Sponsored by the State of New York, Department of Environmental Conservation, Albany, September 16-18, 1970.

24. M. H. Jensen, C. N. Hodges, and C. O. Hodge, "Utilization of Waste Thermal Energy and Diesel Exhaust for Greenhouse Crop Production," Paper Presented at the North American Greenhouse Vegetable Conference, Pittsburgh, Pennsylvania, September 28-October 1, 197C.

25. Geralu' G. Willams, "TVA Program: Waste Heat Utilization in Greenhouses and Other Agriculturally Related Projects," in Proceeding of the National Conference on Waste Heat Utilization, Gatlinburg. Tenn., October 27-29, 1971 , CONF-711031.

26. Merle H. Jensen, The Use of Waste Heat in Agriculture," in Proceedings of the National Conference on Waste Heat Utilization, Gatlinburg. Tennessec, October 27-29, 1971, CONF-711031.

27. J. W. Courter, "The Fensibility of Growing Greenhouse Tomatoes in Southern Illinuis," University 
of Illinoix, College of Agriculture, Cooperative Extension Service Circule 914, 196.5.

28. W. M. Brooks, "Growing Greenhouse Tomatoes is. Ohio." Cooperative Extension Service, The Ohio State University, 1969.

29. S. H. Wittwer ard S. Honma, Gremhouse Tommtoes, Michigan State University Press, East Lansing. 1969.

30. G. A. Fischer, "Report of Greenhouse Vegetable Production in Essex County for 1965. Production Costs, Returns, and Management Practices." Farm Economise Co-operatives and Statistics Branch, Ontario Department of Agriculture and Food, Chatham, On'ario, : 366 .

31. S. E. Beall, Jr., and G. Samuek, The Use of Wom Whter for Heating and Cosing Plont and Animal Enctosures, ORNL-TM-3381 (1971).

32. R. E. Larson, "Concerms of the Greenhouse Vegetable Indestry," Proceeriings of the North American Greenhouse Vezetable Cünference, Pittsburgh, Pennsytvania, September 28-October 1, 1920.

33. Acme Engineering and Manufacturing Corp, The Greenhouse Climate Control Hendbook, Acme Engneering and Mamusacturing Corp., Mudrogee, Okbhoma, 1970.

34. Modine Engineering Manual 10-201, "Gre nhouse Heatives" Modine Manufacturing Company, Racine, Wisconsin, October 1973.

35. Modine Engineering Manual 10-200.1, "FloraGuard Heating and Ventilating System for Greenhouses," Modine Manufacturing Company, Racine, Wisconsin, April 1970.

36. G. F. Sheard, "Greenhouse Vegetable Production in Britain," Presented at North American Greenhouse Vegetable Conference, Pittsburgh, Pa., September 28October 1. 1970.

37. "Report of Greenhouse Flower Production in Cntario - Production Costs, Retuins and Manazement Practices," Farm Economics, Co-operatives and Statistics Branch, Ontario Inepartmeni of Agricuiture and Food, Chatham, Ontario, February !970.

38. 1970 Handbonk of Agriculnowl Cherts, Agrisulture Handbook No. 39\%, U.S. Department of Agriculture, Washington, D.C., November 1970.

39. Chickens and Eess, U.S. Defartment of Agriculture, Statistical Reporting Service, Crop Reporting Board, Washingrion, D.C., April 1970.

40. J. M. Snyder, O. A. Rmoth, I. C. Ssholes, and C. E. Lee, Profitable Poultry Manazement, 24th Ed., Beacon Feeds, Cayugn, New York, 1962.

41. A Cimparison of Returns to Poultry Growers. Marketing Research Report No. 814, U.S. Department of Agriculture, Ecosomic Research Service, Wathin: ton, D.C., February 1968.

42. H. G. Barott and E. M. Pringle, "The Effect of Environment in Growth and Feed and Water Comsinption of Chiskers. 1. The Effect of Temperaticte of Emvironment During the First 9 Days Afier Hatch,"J. Nutrition 34, 53-67 (1947).

43. H. G. Barolt and E. M. Prinde, "The Effect of Environment on Growth and Feed and Waver Combunption of Chickens. II. The Effect of Tespernture and Humidity of Environmenat During the First 18 Dass After Hatch," J. Nutrition 37, 153-61 (1949).

44. H. G. Baroft and E. M. Pringle, "The Effect of Emironment on Growh and Feed and Water Con. sumption oi Chickens. III. The Effect of Texperture of Emvionment During the Period from 18 to 32 Dyss of Age," J. Nutrition 41, 25-30 (1950).

45. P. N. Winn, Jr., and E. F. Codfrey, The Effect of Temperature and Moinure on Braile Pesformmee. Contribution No. 3933 of ine Maryland Apriciineral Emperiment Station, Departisests of Apricalturel Engineering and P ry Science.

46. R. P. Priace, w. C. Wheder, W. A. Jumite L.M. Potter, and E. P. Singea, Effect of Temperentere on

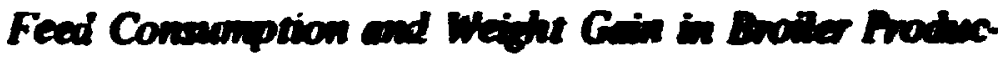
tion, Progrens Report 33, Colleze of Agriculture, Uni versity of Consectiout.

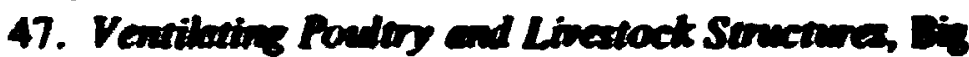
Dutchman, A Division of U.S. Industries, Ine., Zeeted, Michion, 1969.

48. 1970 Asoicultumel Evineers Yendook, American Society of Agricaltural Engimeers, 1970.

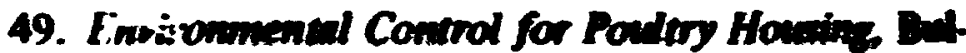
letin 456. Udho Agricaltural Experiment Station, Unas versity of Idaho, Moscow, June 1967.

50. Environanental Control for Alimals and Plants. ASHRAE Guide and Date Book Appliantions / 963 , Chap. 16, American Society of Agricultural Envineers, 1968.

51. G. S. Netson, Controlled Enwhoment for Broiles, Artaneas Experimem Station Dulletin 636. 1963.

52. C. A. Rollo and G. P. MeDanie, "Broiler Howe Insulation - What are the Effects?," Reprimed irom Highlights of Agriculturd Research, Vol. 16, No. 3 , Agricultural Experiment Siotion of Auburn Uaiverity, Aubum, Alabama, 1969.

53. L. N. Drury, R. B?. Bromen, and J. C. Drioners

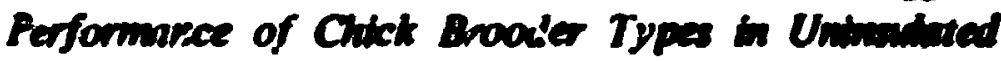
Howses. Georgin Agricultural Experiment Stations. University of Georin College of Agriculture, Bulletin N.S. 101, April 1963. 
54. L N. Drury. R. H. Brown, and J. C. Driwers, Coaline Predary Howes in the Southent. Georgia Avicultural Experiment Stations, University of Ceorgit College of Aqricutture, Dellotin N.S. 115, May 1964.

55: A. D. Lompouse and H. L. Garver, "Poultry Emviromments," ASHRAE Journd, New York, New York, July 1964.

56. H. Ot, "Shelter Engineering for Poultry," Pre semed at the Aseciation of Southern Agricultural Worters Meeting, Mobile, Alabama, February 3, 1969.

57. Agricaltural Sutivetics 1968, U.S. Department of Agriculture, Wenington, D.C., 1968.

58. 197i Livestock and Poulory Imentons, US. Department of Agriculture, Wahington, D.C., February $5,197 !$.

59. Swine Howains and Equipment Handbook, Department of Agricultural Enjineering University of Mibosoni, Crobumbie, 1964.

60. F. M. Sime, R. Hinton, and D. E. Erickson, "Yow Hos Bravens; How Big? How Good?" AEAOS9, Cooperative istemsion Service, University of Illinois, Utbana, 1965.

61. H. Heitmen, Jr., C. F. Kelly, and T. E. Bond, "Ambiem Air Temperature and Woinht Gain in Swine," Sound of Aubual Science, Vol. 17, 1958.

62. W. J. Warwick, "Effects of High Temperatures on Growth and Fattenise in Beef Cattles, Horn, and Streep," The Effects of Chimate on Alvinal Paformance, Reprimed from the Jounnl of Heredity, Watrinton, DC., Vol. XIUX, No. 2, March-April 1958.

63. P. H. Sorenven, Influence of Climatic Envison. meat on Pis Performance, Nutrition of Fis and Powians.

64. D. W. Mangold, T. E. Hazen, and V. W. Hays, "Effect of Air Temperature on Performance of Growias-Finishing Swiae," Tramactions of the ASAE, Vol. 10(3), 1967.

65. A. C. Dake, "Hog House Ventilation," National Hog Farmer, Swine Information Service, Bulletin No. F21, Pundue University.

66. S. R. Morrivon, H. Heitman, Jr., T. E. Bondi and P. Fino-Kelcey, "The Infuence of Humidity on Growth Rate and Feed Utilization of Swine," Int. J. Biometior 142), 163-68 (1966).

67. S. R. Morricon, T. E. Bond, and Hubert Heitman, Jr., "Effect of Humidity on Swine at Hith Temperature," Reprinted from the Transactions of the ASAE, Suiat Joneph, Michiogn, 1968.

68. T. E. Hazen and D. W. Marqold, "Functional and Dic Requiresents of Swins Housing" Reprinted from Apriculturd Endinceriog St. Jowph, Michigan, S:Ptember 1960.
69. T. E. Bond and G. M. Peterson, Hog Houses, USDA Miscellaneous Publication No. 744, 1958.

70. Hog Equipment and Shelters for Southern States, USDA Agriculture Handbook No. 115, 1957.

71. Hog Shetters and Equipment. Agricultural Extenson Service. University of Temnessee, S.C. S12, 1959.

72. P. L. Stroman, "Conditioning Swize Structures," Presented at Southeast Region Meeting of ASAE, Jacksonville, Florida, February 1971.

73. O. M. Hale, R. L. Givens, J. C. Johnson, Jr., and B. L. Southwell, "Effectiveness of Morbble Shades and Water Sprinklers for Growing-Finiching Swire," Reprinted from Journal of Animal Science, Vol. 25, No. 3, Iugust 1966.

74. T. E. Bond, H. Heitman, Jr., and C. F. Kelly, "Physiokgjical Response Time of Thermally Stressed Swine to Several Cooling Media," Paper presented before the Vith Intermational Congress of Agricultural Engineerine Lausanne, Switzerland, September 1964.

75. W. N. Garrett, T. E. Bond, and C. F. Kelly, "Effects of Air Cenditioning on Fattening Hogs," University of California ead U.S.D.A., Devis, California.

76. J. A. Mertel ani T. E. Hazen, "Zone Cooling for Lactating Sows," Trans. ASAE 10(4), 444-47 (1967).

77. R. M. Jimeson and G. G. Adkins, "Factors in Waste Heat Disposel Aseociated with Power Generation," Presented AICHE, Houston, Texas, February 28-March 4, 1971.

78. T. E. Hozen, personal communication, March 22, 1971.

\section{AQUACULTURAL USES OF WASTE HEAT}

Aquaculture is an ancient art. It has been practiced for centuries in the Orient, particularly in the tropical and subtropical areas where framers raised fish in flooded rice fields to provide a protein supplement to their basic grain diet. ${ }^{1,2}$ Yet the practice is alm a new technology. A few fish species have been intersively cultivated in controlled envirnnments, and yields of these species have been enhances by the degree of management exercised over the cperation. ${ }^{3.4}$ In pond culture, for eximple, with nitrogen and phosphorus fertilization, yields for carp are $100-600 \mathrm{lb} /$ acre-year at ittes in Israei and Southeast Asi:. With supplemental leeding, these yields increased to $1600-2400 \mathrm{lb} /$ acreyear. Most impressive of all are the yields in runningwater culture with intensive feeding as practiced by the Japanese. Yields of 0.8-0.3 million ib/acre-year for carp have been sblained. Catfish culture in ponds under semicontrolled conditions may yield 2000 ib/acre-year," while yields as high as 2 million lb/acre- 
year for catfish and trout might be achievable in intensive culture in a flowing stream with a relatively hich degree of environmental control.' By contrest. firhing for wild spaties on the continental shelf by trawting and purse seining may yield only 20 b/acreyear."

Aquaculture is more like farming, wheress fiching is Tike hunting. "Thile yields from aquaculture canaot be compared witn yields from fisting for wild species, the contrasi provides an insigint into th: potential ion squaculture in supplying future fish dezannds.

The methods described bove are all semomal sctivities. No attempt is made to mintain the temperature of the culture system in the uptimum range for growth. Yet basic data on fich growth indicase the potential benefits of maintaining optimum tempersture (Fi. 18) For example, shrint gaowth ${ }^{10}$ is increased by $80 \%$ when water is mintained at $80^{\circ} \mathrm{F}$ instead of $70^{\circ} \mathrm{F}$, and catfish" ' grow inree times faster at $83^{\circ} \mathrm{F}$ than at $76^{\circ} \mathrm{F}$. Growth of both both equatic species benefits apprecimbly more from temperature control than does gromth of animals such as broilers, coms, and swine.
Heated diachange water from stean poner phose represents a bre tiermol esersy source for mintaining the temperature of a colkure mediven in a reve tim is optimam for the gromth of some apentic species Abo, electricity is swibble for punpines power, perinition

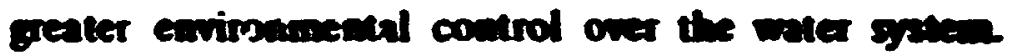

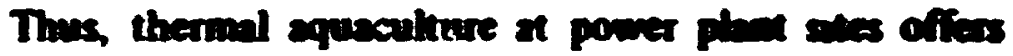

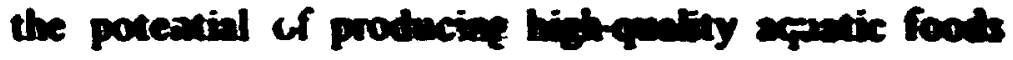

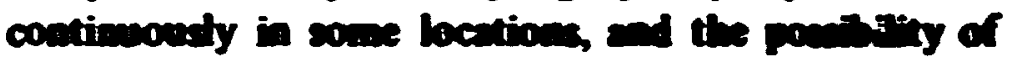

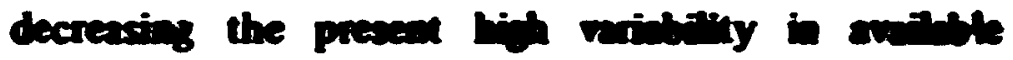

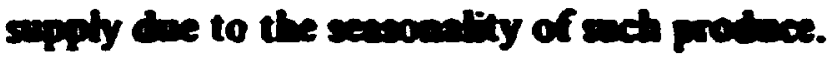

Tempereture control alowe, kowever, is wor sofficient

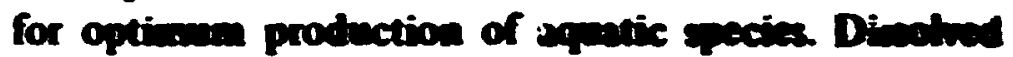

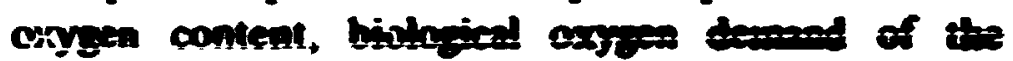
culture systern, fich wate costrol, and otritiond adequacy of the food tiat are some of the otwer important variebles that abo influeace yiell.

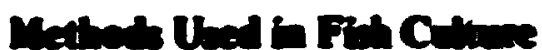

Or the 2500 known fint species, tes the $1 \%$ of then

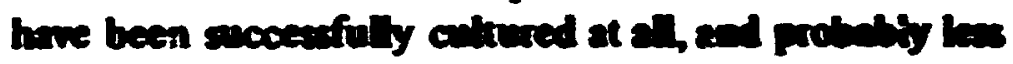

canc-ows ro-473n

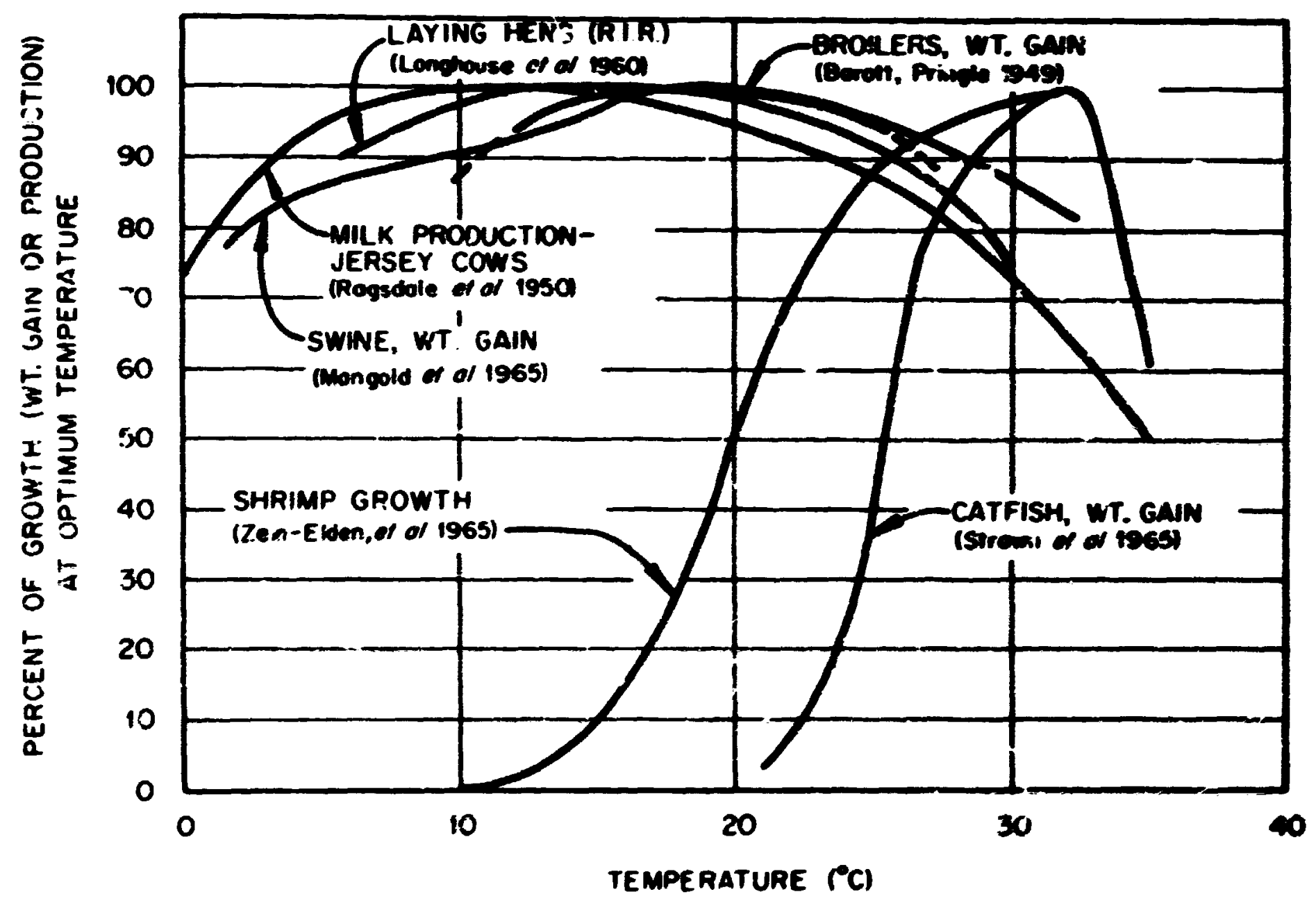

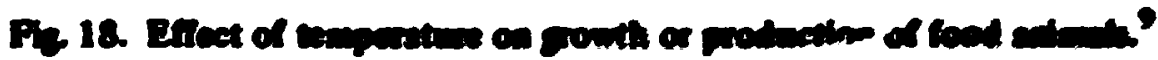


then $0.5 \%$ of them have been intessively costured $3 \mathrm{sin}$

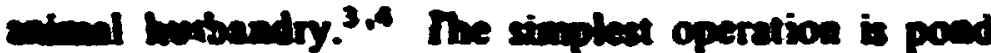

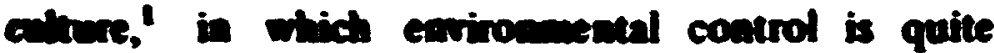
linied and vaible. Here fich are sinply stocked in a boty of weter. At bow stocting mes (bandreds of ponats per acre), fich cea exiot on mtual food in the

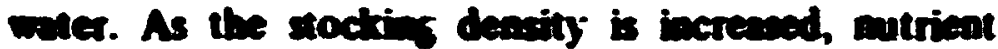

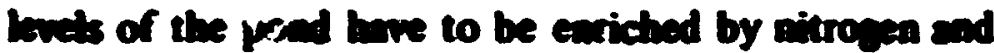

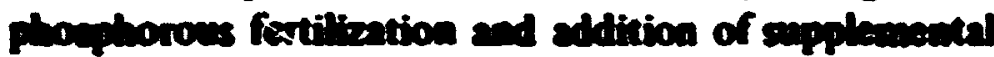

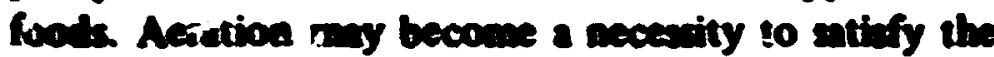
increaned metabolic oxysen requirements. In eddition, builep of fis wetes and oxyren conumplion by otver equatic orgenims in the system become inpor. ture fectors in overubluing the syotedn.

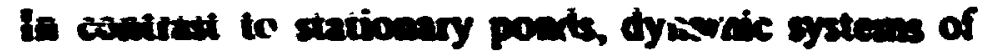
culmere cen offer 2 greater depree of enstonmented coatrol. Fich can be confined in cerest2 (e.e., $30 \mathrm{ft}$ low $X 10$ if wide $X$ I fi deep) and placed in a boge

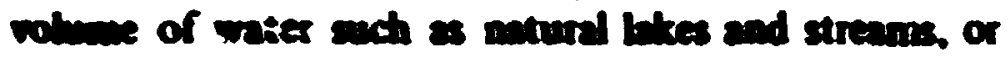
cooline proads or chanants of coolant water. A preater

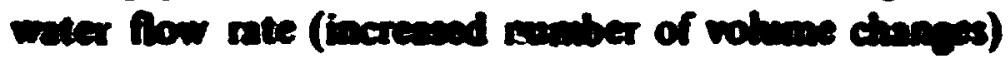

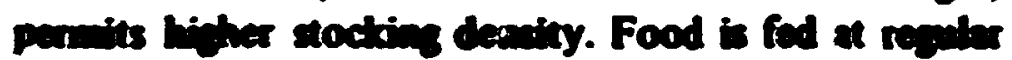

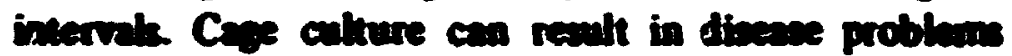
when is is carrisd on in bope boties of water where will fich popelations $e$ aid and the fin in colture canot be ioloted. 12

Flowing water culture is abo precticed in maliple chanads or recewass, each of which mingt be $100 \mathrm{ff}$ low $X 4$ if wide $\times 5$ if deep in a commencial operation." 3 Water depth and flow rates can be

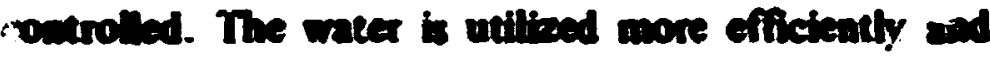

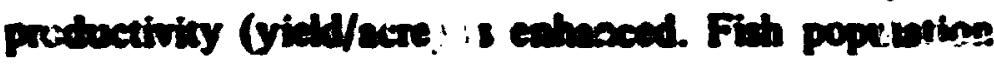

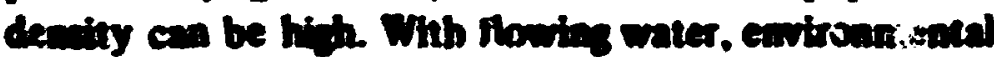

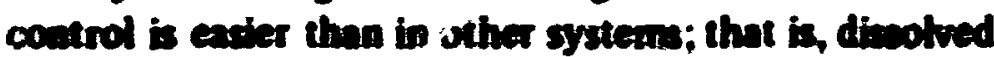
oxysea is diaributed more uniformly ard blobojical oxyen denand is lowrer becuses fich wextes are flushed away. However, capialal coats are sbout ten times that of the pond or coepenture."4

\section{Convent Techosinges}

Catrish is conmercially the mon widely culsured finh in this country (bout 54 million it in 19?0). ${ }^{13}$ Thts is - warminder species whose optimum growh umpers. ture is between 80 and $90^{\circ} \mathrm{F}$. Senconal culture is carried

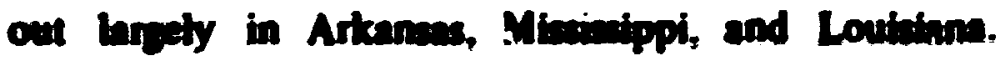
Farmen uovally fit thetr culture ponds in the sprine.

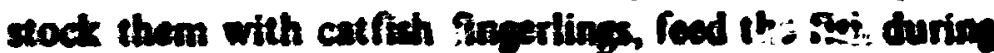
the growis seacon, harvest them in the bate fels and all them to proceseors who market the reepared ponduct. However, thit simple culture molnow is not without problems. Fifh remperatures and bow dimoolved oxyrea concestrations can result from solex hoting of the ponds and pond stratification. Sudden aba blooms con incresce biolonical oxyen demand in the poid

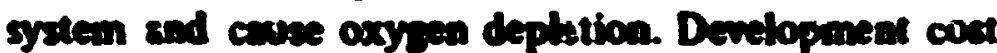
for exch poods is bout \$100 to \$1200/ecre.-

Soune of the newer commercial catfish culture proj ects are inore sophinticated in desion. Flonting cases 12 have been plased in flowing waler, or $70-75^{\circ} \mathrm{F}$ I toundmater has been pumped contivuoudy into circur.

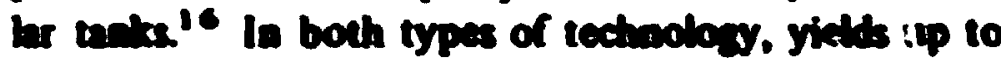
200,000 b/ecre-year of better hrve bean re parted. 12,16

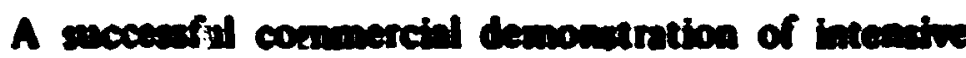

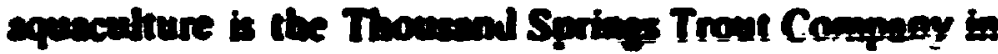
Bubl, Idabo.' This the bagent farm of is lind in the word, sepplying 30\% of the US matter (4-S million to in (969) for riabow irom. " Y Yilds of 200.000-

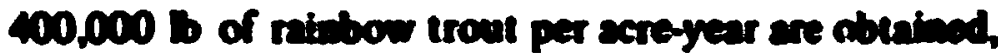
and each year shipmestes of 1.5 million so of dreand troen are ande 10 domantic and foreipg matete The

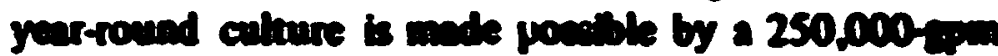

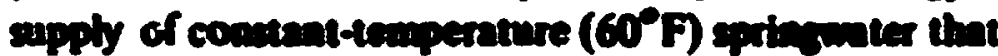

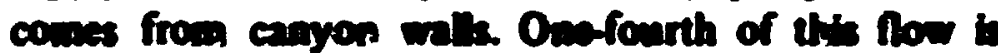

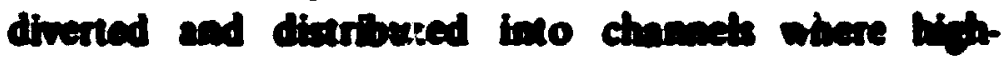
dewity calkure is practiced. Al a socking demithy of 2 $b / f^{3}$ of water, the winter of ribbow irout mpportad

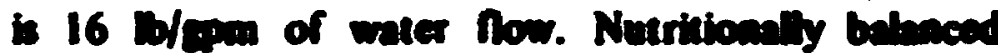
pelbetined food is fed at repalar intervel, and an creallent fred cownerion ratio of $1.5 \mathrm{~b}$ of dry food fod per to of wet fich prodeced is normally achicued. The comanercid uperation includes food formulation and mixture, culture frem the of in the betchery to promith

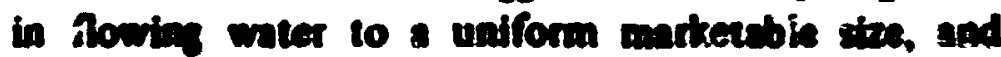
proceading of the harvested fich to a frosen pactesed product. The uncommonaly frech laste and firm meat of this trou! are atrributed to the flowing wales which

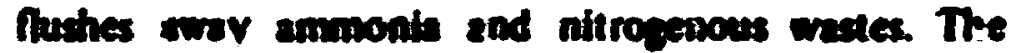
aneraye wholesale price for the product is in the middle tw upper portion of the price rane for rainton trout, S0.85-1.15/70 (1971 price).

The tectatical success of thin exterpitise is probebly twe to the hing-quality water at the culture sine. coupled with sumeient knowledre cbent rinbow trone

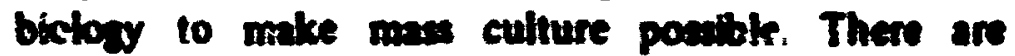
relatiwly fow sites with such a dopandable source of water and only a wry few squatic spacios whose biological charecterbstes are known well enowh to permil auch as intencive cperation.

A dependible martet for the cultured product is anential to the financial meceis of the operation. Twere have been nenviones inatances of interpribas which wers

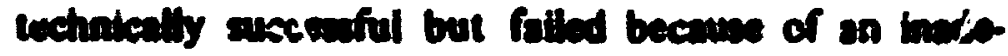
puate matreting arrangoment. ${ }^{18}$ 
Some senwater species have abo been criltured on a seasonal baxis. Raft calture of oysters and museds has produced 2000-200,000 $\mathrm{Bb}$ of product per acre of water surfece along the shoretines of Austrilia, France. Japan, and the United States.3.4 The nou favorable sies for these rafts are areas where the mutrient concesatrations are etriched by the drainge of rivers and exauries and where bre volumes of moving water are anibble to carry matural food applies to the mobile refts. Ahboush so entindy suitsble ford formu.

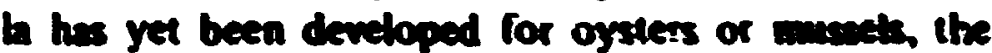
matrient content of the water can be further enricted by the addition of ninroyen and phoophoris fertilizers. Yields may be dradicelly reduced by predater atteck (oyster drith and starfich) when the faciliny is not bolued from the sea. Four years of cuhure are

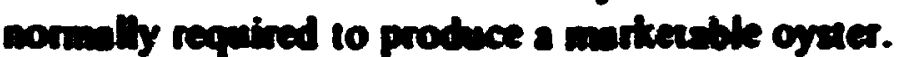

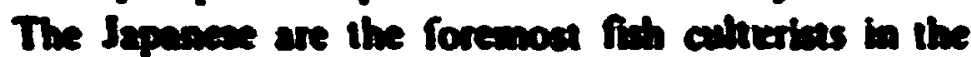
world. 3. Alom the bay areses of Jeparis Imand Sen

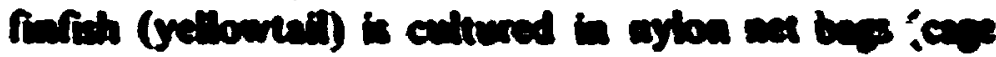

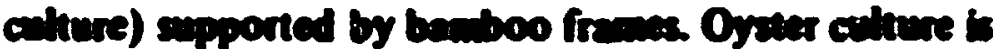

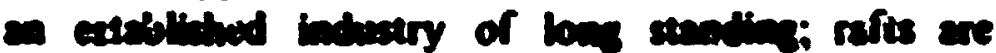

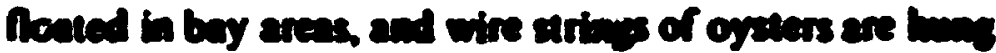
from a bitice work on each refi. Where the oyaters bied by pumpine semweler and exirection the surible

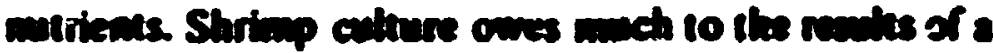
30-year effon by M. Fuseng 10 parect metbods of

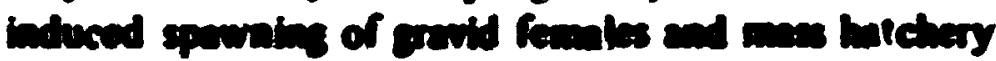

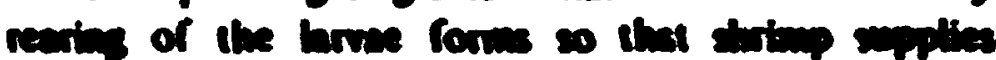

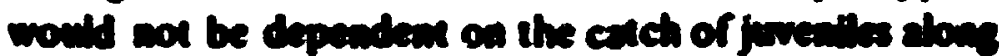

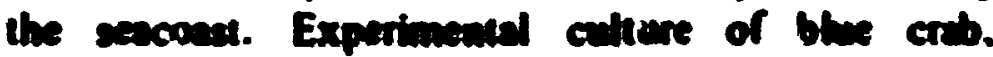

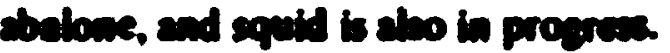

Several voriaties of somed (Noril and alpe (Undario) are colbered by the bepeneas for we as a

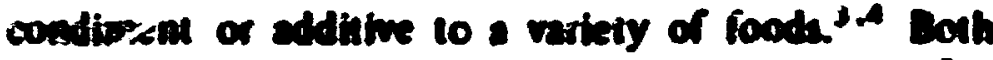

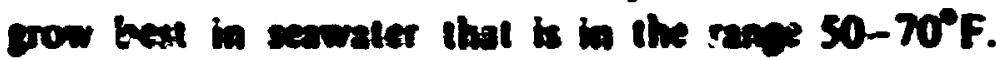
Monospores cathused in indoor tadks sce treneferred to nets of string anpended on remboo rafis and allowed to grow durias the bate fall and eaty witurer bu stallow

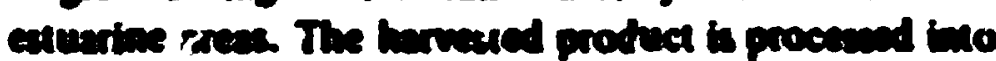
thin driad sheets and sold it packets of 6-tin. shoets. Is 1907. Nori production wo 140,000 toen and Undurt was 67.000 loms.

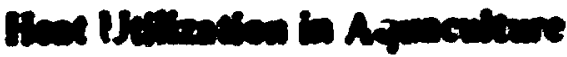

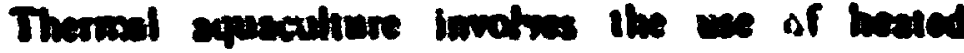

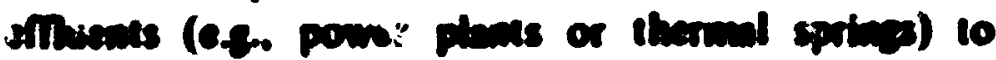

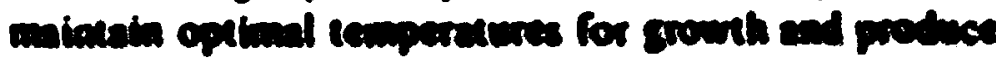

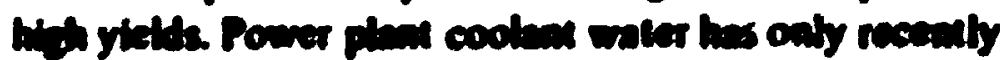

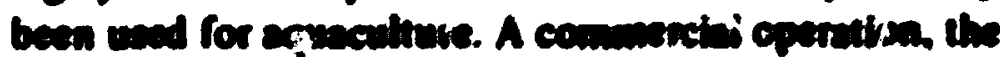

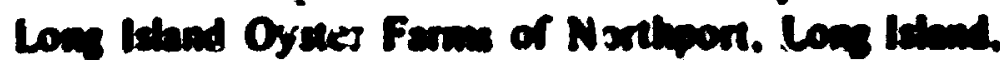

utilizes the thermal efmuent of Long Istand Liphting Compeny for the earty stapes of oyster culture." Normal souving periods of four years have been reduced to 2.5 years by setretive breeding. spewning. larve growth. and "seating" oysters in the hatchery. This avids retiance on varisble motural conditions and pernits sccekerated gromh is the thermal efllween disctarge beoca over a period of bove 4-6 montabs. when the water would otherwine be 100 cold for maximem growth. Oyster cultere is completed for martet in the cold waters at the exmern end of Lom Istand Soond. The product is barmened, procenod, and marketed for S15-2010mind (1971), the riper sad of

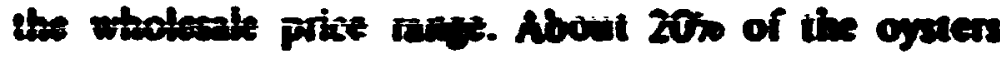
"set" in the betchery resein in i berveded prodect.

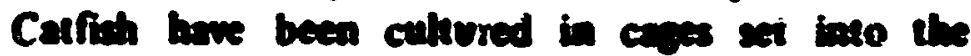

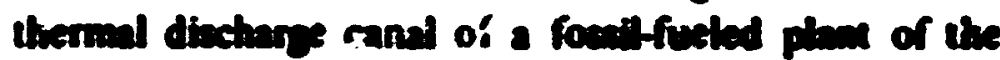
Texes Electrit Service Company at Late Colondo Chy.

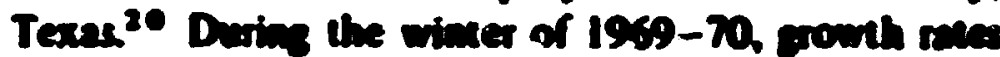

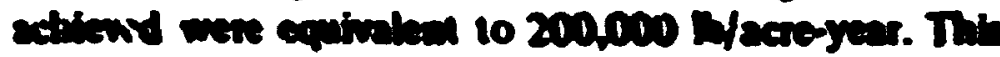

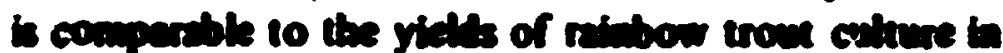

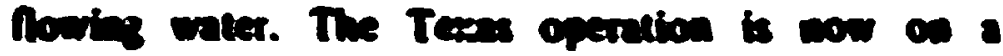
conmancial inder.

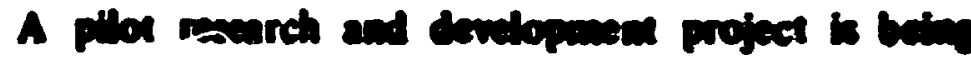

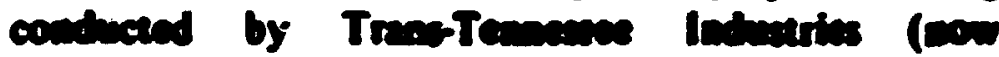

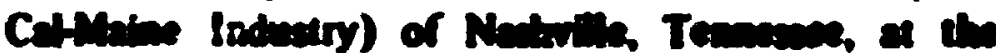

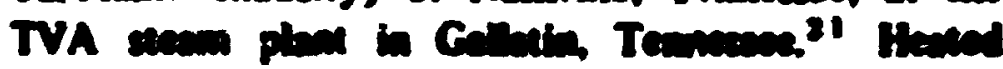

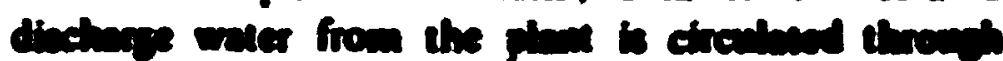

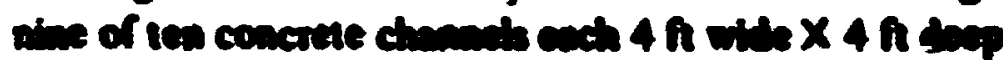

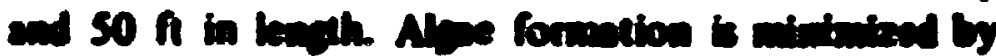

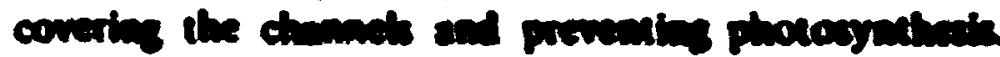

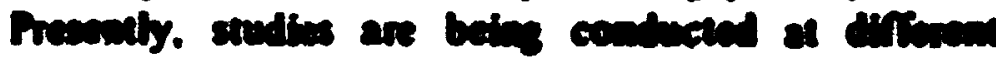

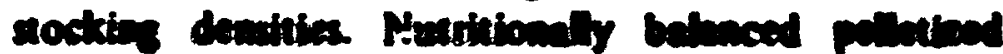

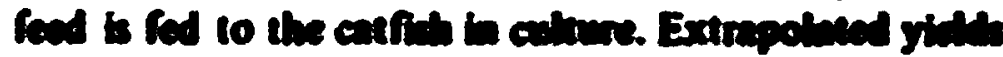

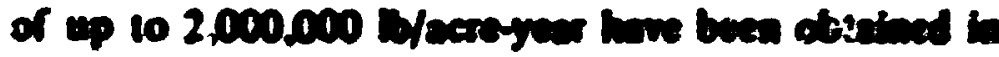

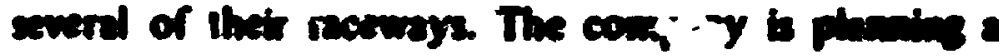

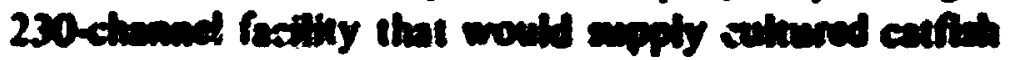

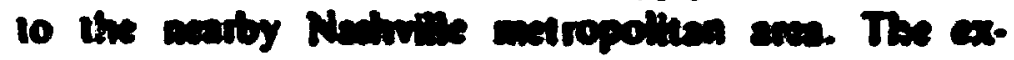

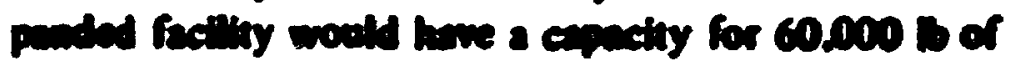

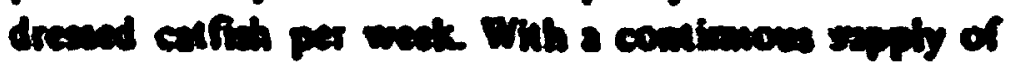

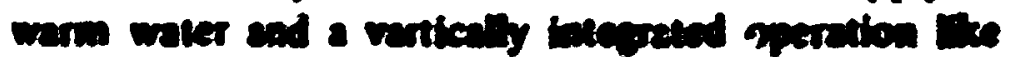

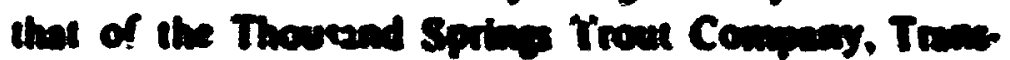

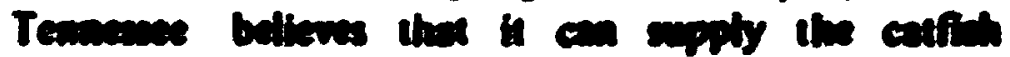

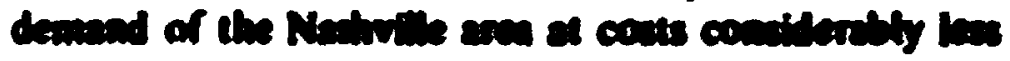
ther pond production cones for conith.

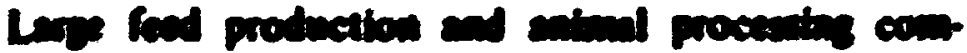

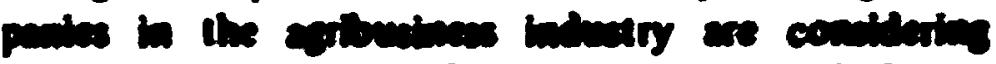

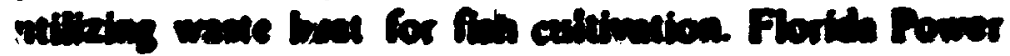

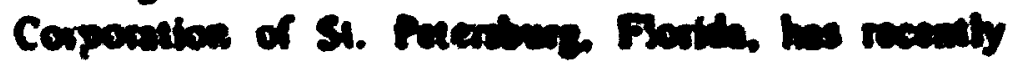

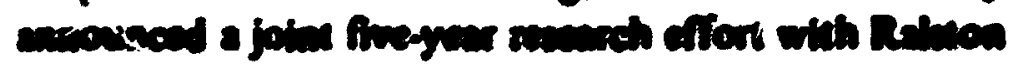

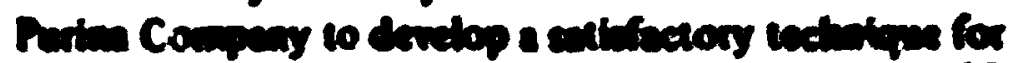

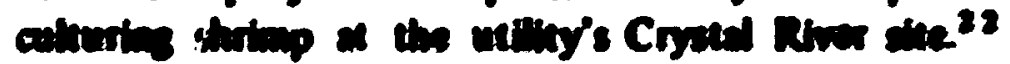


Armoor and Urined Frit have conducted a sintll research effor on strivep collure in coopsration with the Universiny of Minmi at Floride Power and Liphe Company's Tutkey Point facility. ${ }^{23}$

Smaller companies the Intersational Shellfich Enterpribes are developing methods for oystei calture in the thermal diestanes canal of Pacific Gas and Elsetric's phat at Hernboldt Bay. 24 Marifarms, Inc., of Panean City. Firrith, is utilining the warm water from the local power phan 10 manesen pond temperatures in wister so

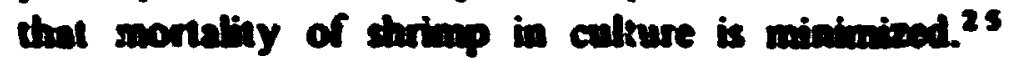
Experimencal bobne calkure using warm waler is beine comidered by a fow innirutions, inctuding a Calfornia prom (San Dieso Cos and Electric Compeny and Maricakure Resench Corporation) and the Departwent of Sen and Shone Fuberies of the state of Mrime ${ }^{20}$

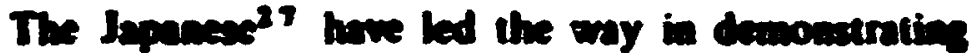
the bewefits of waxe beat utilization for sepmocelture.

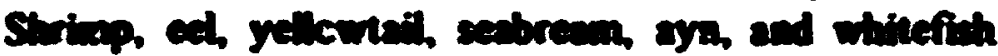
se being colvured Culbure experiments sartad at the

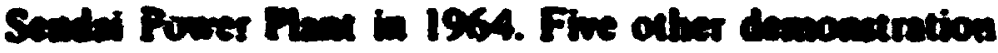

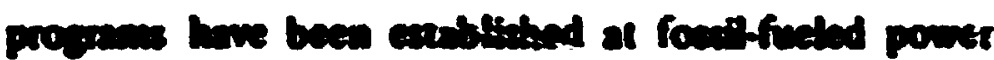

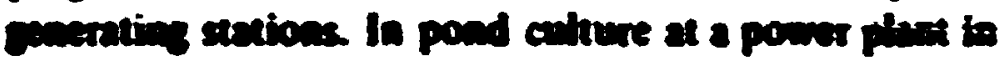

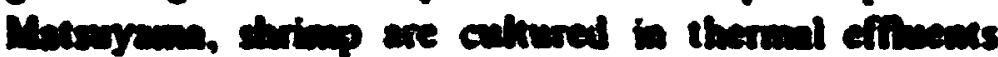

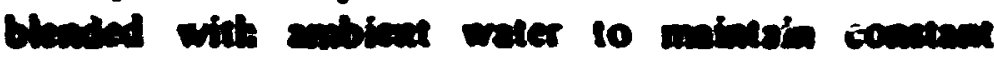

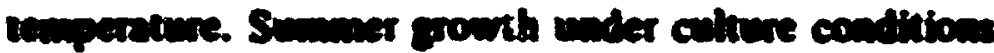

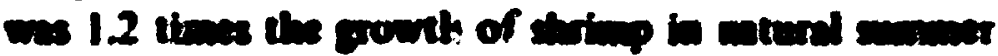

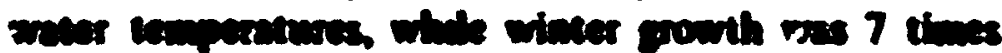

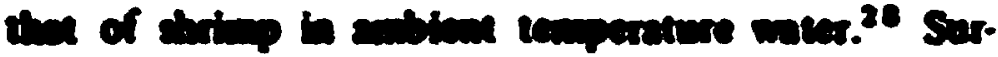

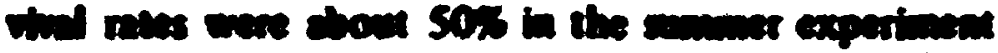

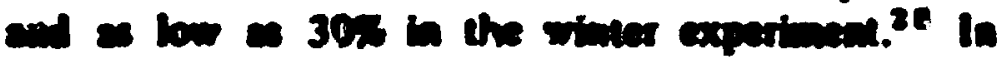

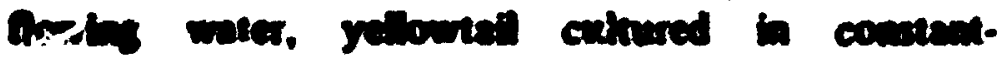

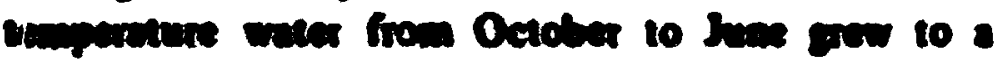

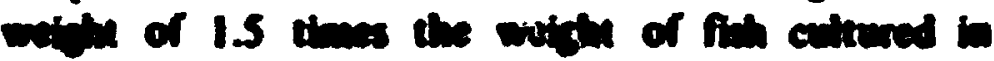

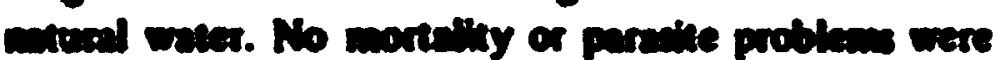

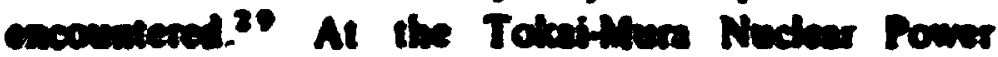

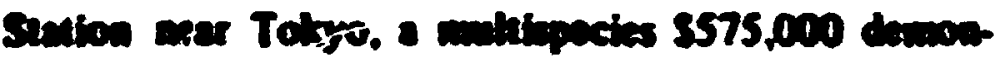

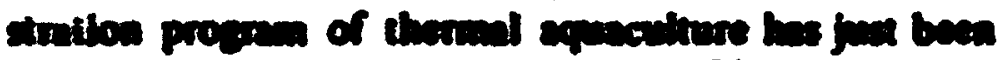

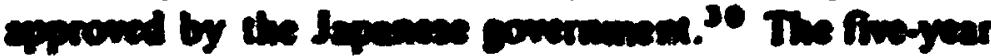

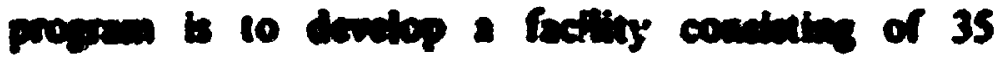

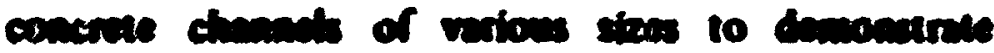

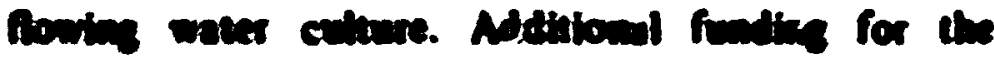

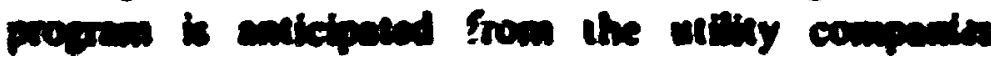

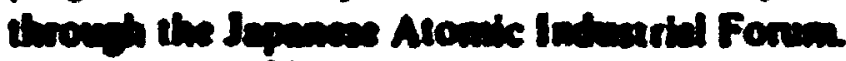

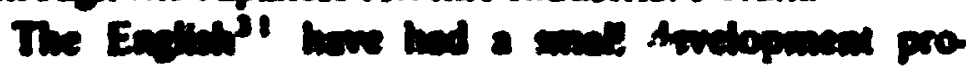

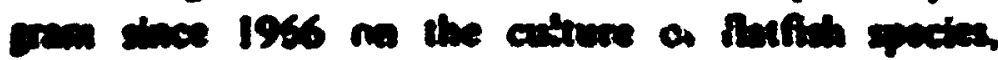

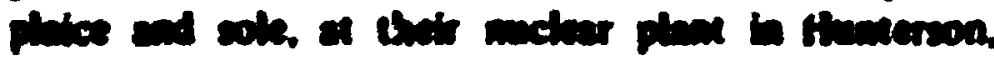

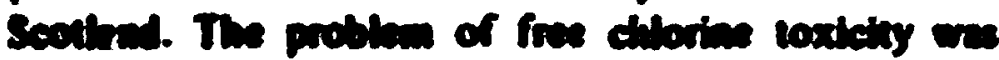

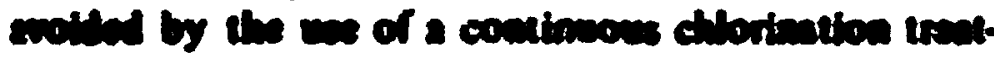

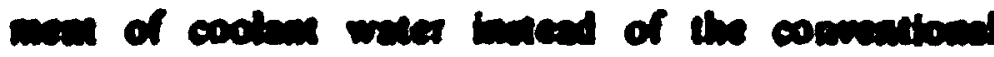

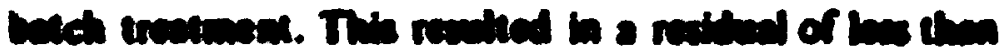

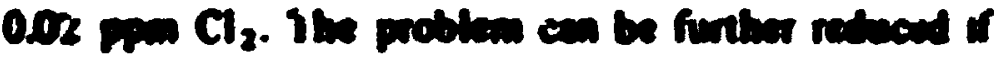

the power plant uses mectanical cleanian techniques. No radioactiviny is allowed to ive dibuted into the coobant water strean uned for expaculture. Althorenth culture of the fatfich species his been demonstrated, widespread culture hes been restricted by bow food conversion efficiency and hinh food coets. Lomberbe fich is used as feed, and a saitsble low-con, formalned food bas not bees developed. Flatifh are cultured in Now through pouds rear the shocktione. Since the system is sol inobed from the sea, predator actack and disene are of concera.

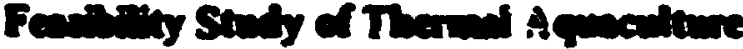

A thoroming feribility study of a conceptual deaing and the maket polemid for a shrimp calture faciliny

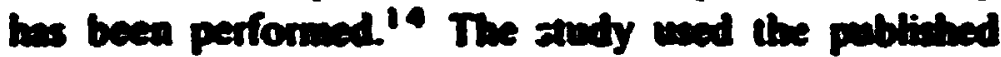
bata on string biology and tecthoology to develop a

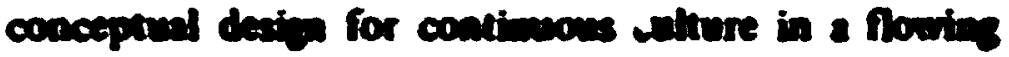
strean A cout entimale, o cost semitiviny anblyis, and a marter projection for the culbured product were do

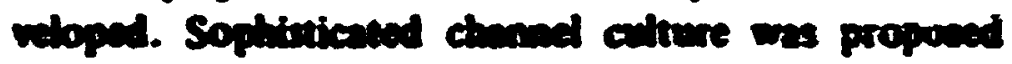

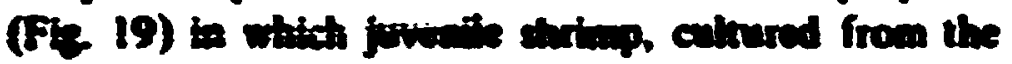
os in a backery, would be rind in a series of pess of

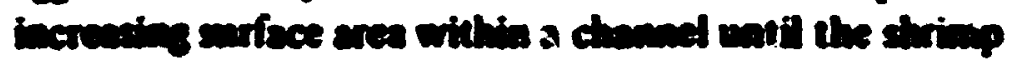

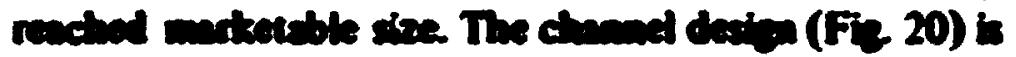

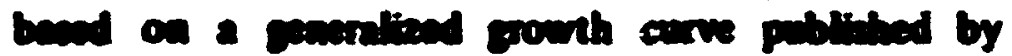

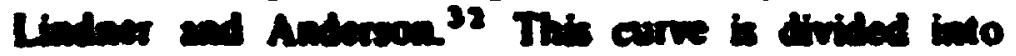

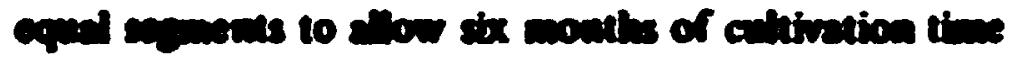

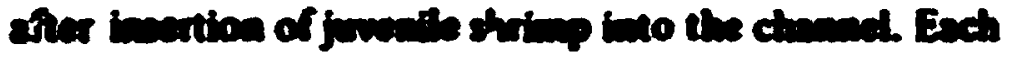

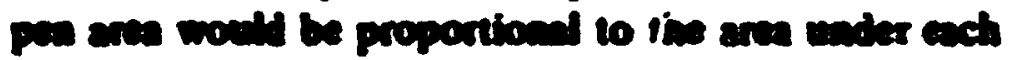

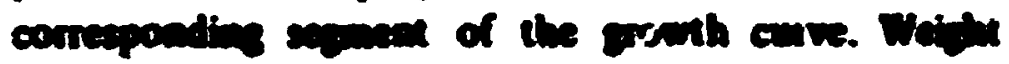

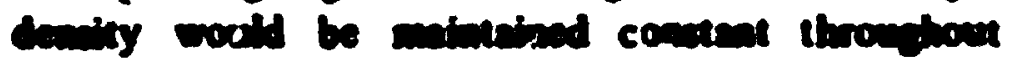
coltere by moving batchess of strimp to proptesivaly

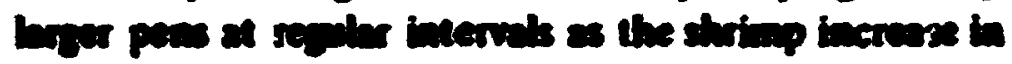

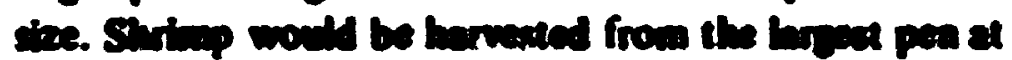
the and of the culdivetion period. Orber stritap in

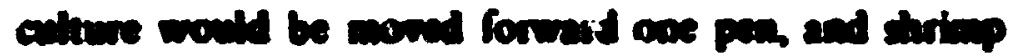

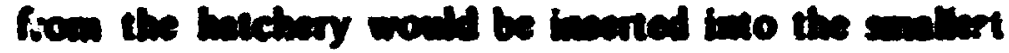

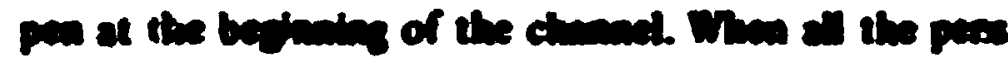

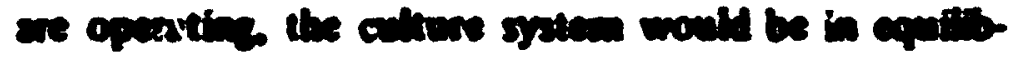

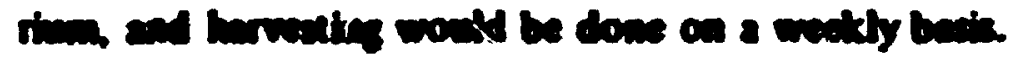

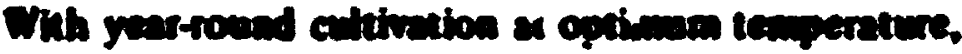

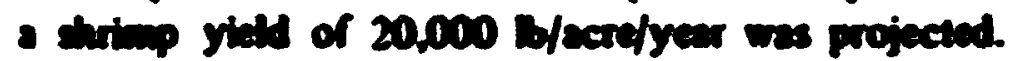

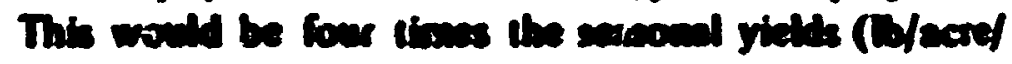

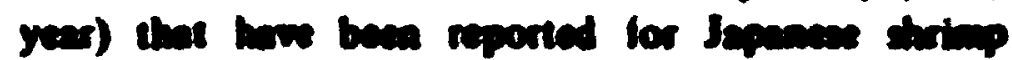

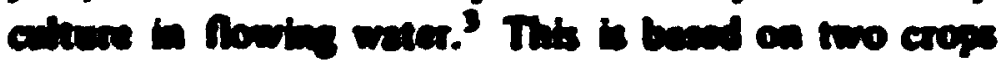

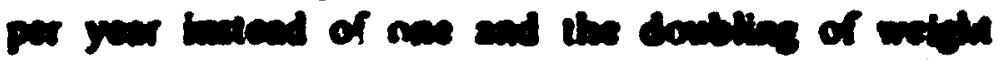

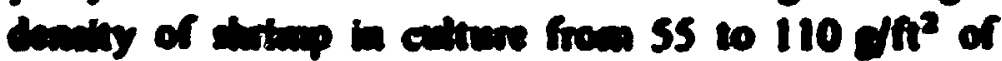

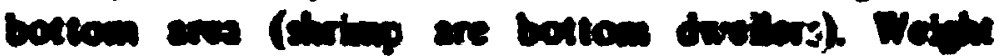

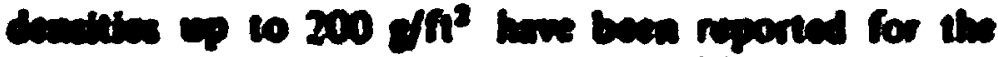

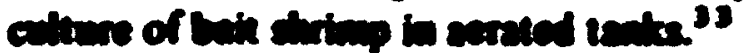


A detailed cost estimate was made for this integrated conceptual design and inchuded feed preparation, shrimp sulture from exas and larve in the hatenery to growith io a harvestable size in channets of nowing water, and processing to the froeen product. For the sosumptions made, the calculations showed a yield of $10 \mathrm{million}$ b/year of shrimp which at 1970 market levels would have a wholesale vaive of $\$ 3.00 / \mathrm{b}$. Production costs were extimated to be sbout $80 / / \mathrm{b}$.

The production cost was found to be most sensitive to feed conversion ratio and leas sensitive to labor consideratiors: capital cosis for site improvement were intermediate. Low-cost, nutsitionally balanced feed is important to the ecomomics of strimp culture, becmise in constitutes more than 60\% of the cotal operatine cost. To date. no feed has been successfully tested for the mass culture of shrier. although food formulation test programa are currently under way both in the United States and in Japan. In this country, formulated feed bas been developed only for the mass culture of nainbow imout. This same feed. however, has been used for the mass culture of saler foh. In Japan, shrimp in culture are fed low-value fish which give a food conversion of $10 \mathrm{Bb}$ of feed to $1 \mathrm{~b}$ of Hesh $/ \mathrm{th}$ is economically feasible to do this, because retail prices for live cultured shrimp command a higher price in Japan than in the United States. ${ }^{34}$

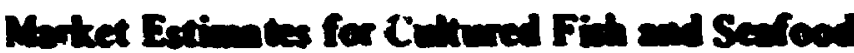

The potential of thermal aquaculture is rehted not only to technical fensibility but aboo to mankets for the products. There is linte statistical data at present to indicate the extent of demand for cultured aquatic foods in this country. In Japan, fish is a prime source of protein, and the per capita fich consumption in 1967 was $120 \mathrm{Do} /$ year, an onder of magritude above that in the United States. Aquaculture in Japan represents a significant tonarge and monetary value in the fisheries industry. In 1967, the total catch was 15.6 billion b. with a value of nearty $\$ 2$ billion. Aquacuiture products totaled 940 miltion bo and were rabued at nearly $\mathbf{\$ 3 0 0}$ miltion, sbout $6 \%$ of the total catch and $15 \%$ of the

Oann Dimg. 70-1632A

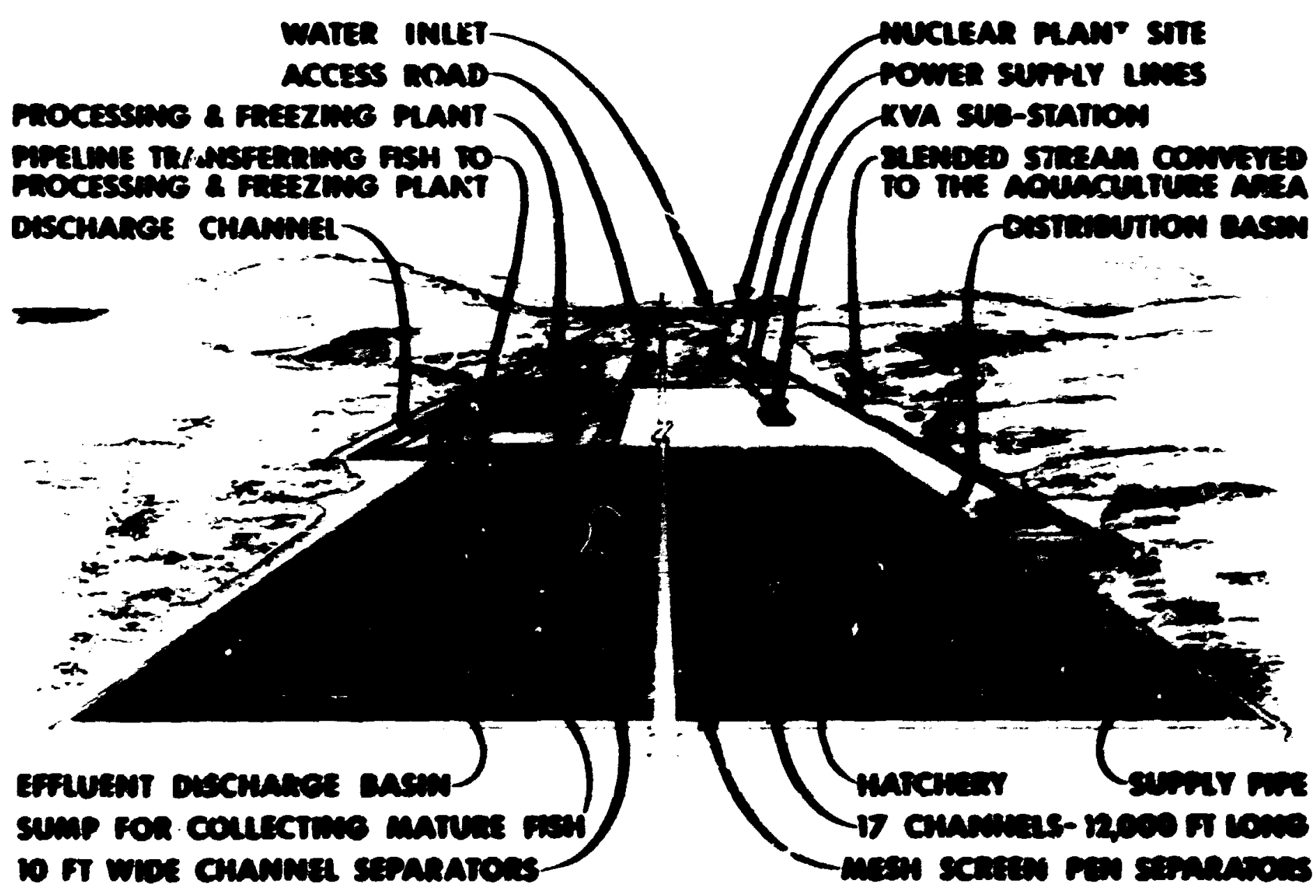

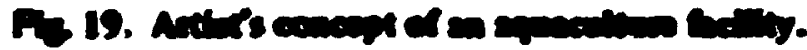



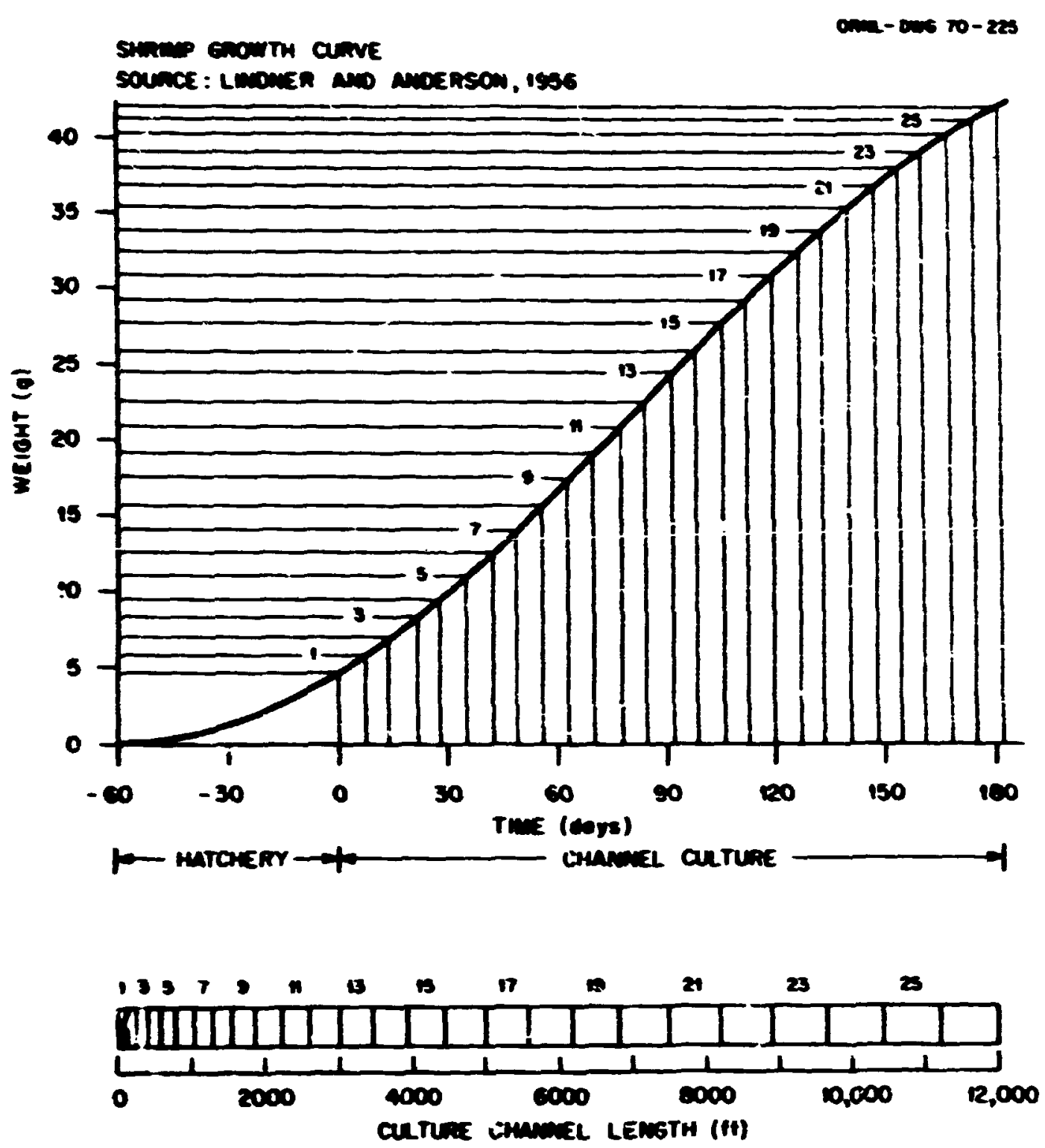

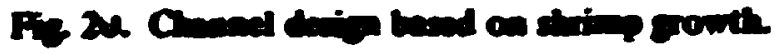

total value. Certain cultured profucts can command hxury prices in Japan.

As mentioned carlier, the yelluwtail fish of the tuna family has been cultured extensively in Japan. In 1963, $60 \%$ of the Osaka maket for yellowial was furnished by squaculture. By 1955 , production reached 36 million D, but further production increases were threatened by a bois of metural supply of small fry. By 1968, antificial propagation was succeasiully developed so that future demands for the fry could be met. ${ }^{35}$

Present difficulties in providing a conasant supply of finh have presented serious problems to the seafood induatry in the United States, and the scarcity of certain seafoods is given as the most serious problem by the U.S. senfood industry. ${ }^{36}$ On a world busis, seafood anduppion represents the fested growing food area, ben world anetained yield from matural sources will be irvitie for many sperias within the next few Jecdeas6 Culturing of finh and other seafoods would reduce this problem. In the United States, aquaculture is in its infancy. Statistical data ${ }^{3}$ show that during the past decade to:al adibl: fishery products have risen from 4.3 to 6.2 billion lb. The domestic catch, however, has remained approximutely constant at 2.0 to 2.5 billion b, while the imported supply has increased from 1.8 to about 3.7 billion $1 b$. I ess than 1\% of the total supply is furnished by fisch culture.

However, statistical data previde an incentive for considering the culture of high-value fish species. For example, in the period 1950 to 1970, shrimp per capita consuraption rose $160 \%$ from 0.8 to $2.0 \mathrm{lb}$, while total consumption of all senfoods remained relatively constant at about 10-12 $\mathrm{b}^{37,38}$ Consumption of meat, poultry, and fish combined rose by $40 \%$ in this same perrod. "Although the domestic catch of shimp is the largest in the world, imports constitute more itan 50\% of annual total supply in the Uri.ed States. There is no impont duty and no quota placed on the amount 
imported. The National Marine Fisheries Service has indicated hat shrimp consumption is less sensitive to price changes than is beef and pork consumption. They predict that the annual per capita shrimp consumption wili exceed $3.0 \mathrm{lb}$ before 1980. They feel that the fraction of shrimp supply imported will have to increase to meet the added demand. By 1980, world shrimp demand will equal the world's estimated harvest poisntial, and they feel that beyond 1980, aquaculture will have to supplement world supply in order to continue to meet world demand (Fig. 21). ${ }^{40}$

In general it is speculated that the dollar value of fishery imports will rise faster than the annual tonnage imported, because a greater fraction will be high-value species." 1 Lomestically cultured fish products can be substituted for some of these imports, provided the operation is economically viable.

Some food market analysts predict a growth in U.S. fish consumption through development of a new aquacultural industry based on advanced technology. This has occurred in the chicken broiler industry. ${ }^{42}$ For the 30-year period 1939 to 1969, per capita consumption of chicken rose from about 1.5 to abcut $\mathbf{3 5 . 0}$ lb/year, while per capita fish consumption remained at 10 to $12 \mathrm{lb} /$ year. In modem broiler technology, food conversion ratios improved from somewhat less than 5 $\mathrm{lb}$ of feed per $\mathrm{lb}$ of flesh to aboitt $2 \mathrm{lb} / \mathrm{lb}$.

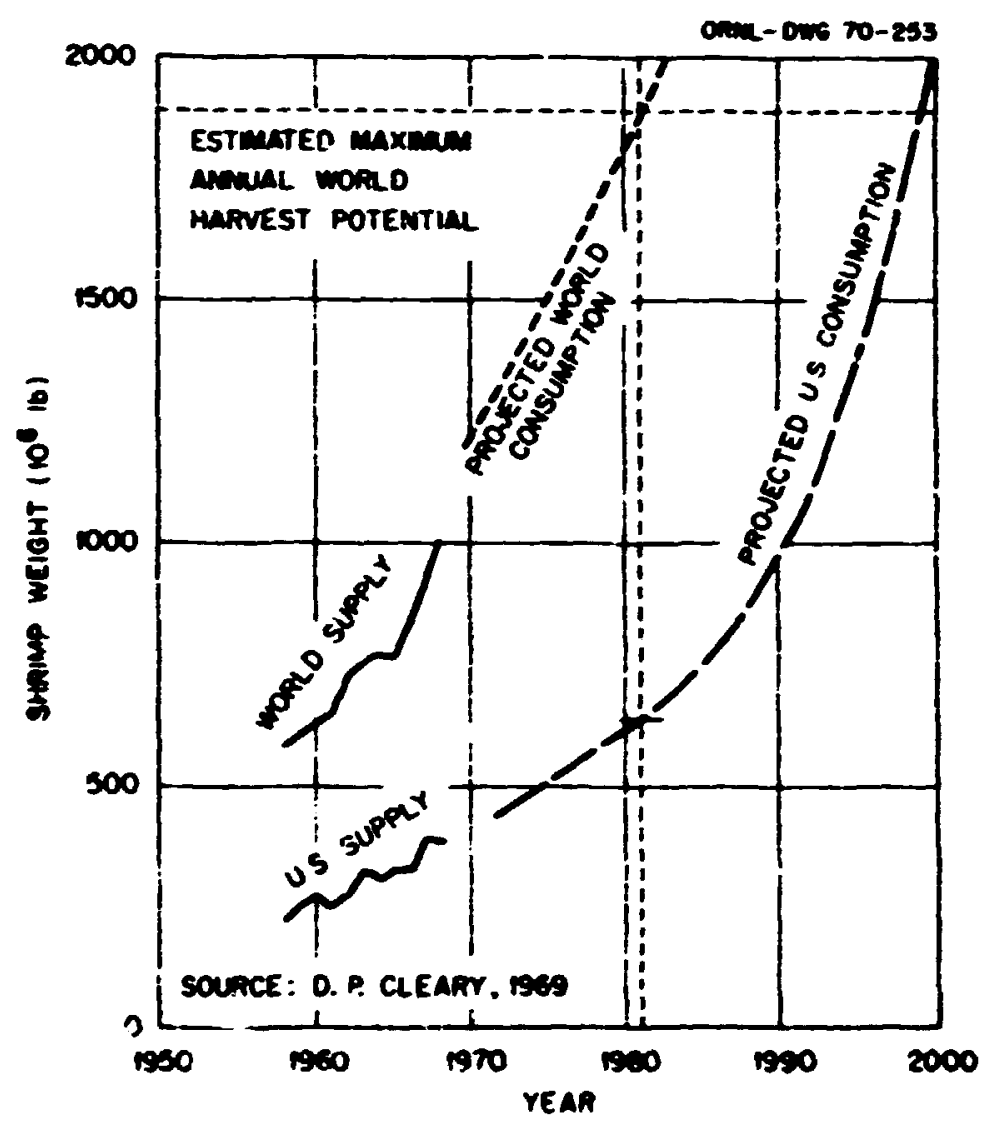

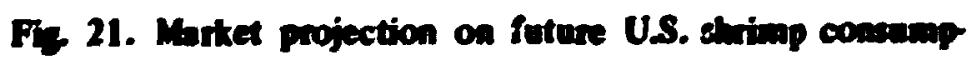
iron (headooft strines).
Cultured species like catfish and rainbow trout under adequately controlled environments do convert mutritionally balanced feed to flesh as eff ciently as in broilex production or better. For some other species tike shrimp, food conversion efficiency is low because suitable iood formulations have not yet been developed, and only natural foods bike low-cost fith on be fed at this time. Food formulas are being evaluated now, and with other improvements including environmental control, a cultured product that is superior to the corresponding wild species could siznificantly atter the per capita consumption of fish foods in the future.

\section{Potentinl for Heat Ut intion}

Fish culture facilities may be located at power phast sites to utilize land area surrounding the power plant. Power and water are available to blend water strems to achieve water temperature control. Flowing-stream thermal aquaculture may formit year-round intemive culture of some species, an improved product quality over that cultured in a pond on a seasonal bais, and a significant reduction in thi costs of culture.

Estimates on the growth of thermal aquaculture in relation to waste heat are difficuli. Few demonatration projects are available, and jield data are scarce. One may gain insight into the reistionehip between heated water availability at power plant sites and the potentiol for aquaculture from the following asmuptioas:

1. Water utilization. About 2000 MW of wate heat is generated for each $1000 \mathrm{MW}$ of electricity produced. About 1000 million gallons per day (Mal) of coolins water is required to dxsipate this waste heat with a $20^{\circ} \mathrm{F}$ rise in water temperature. If the average ambient temperature of the inlet water is asoumed to be $50^{\circ} \mathrm{F}$ for the colder half of the year and $70^{\circ} \mathrm{F}$ for the warmet half, and if $70^{\circ} \mathrm{F}$ is the temperature te be mintainad for best growth, then heated efnuent (at $70^{\circ} \mathrm{F}$ ) would only be used for thermal aquaculture during the colder half of the year. During the warmer half, ambieat temperature water at $70^{\circ} \mathrm{F}$ would be ued instead of the heated effluent at $90^{\circ} \mathrm{F}$. Thus heated woter would be used only half of the year. Even during this period the heat is not "consumed," and "thermal polution" is not reduced significantly.

2. Fish yields. The 1000 Mgd $(700,000$ and of water is distributed over 1000 acres of working water

\footnotetext{
In reality, the source of water at ench power plunt dite las in

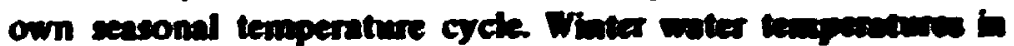
many beations reach $35^{\circ} \mathrm{F}$ for a for month, and powth risis would be low during this paind.
} 
surface. This is abou" one-half the size of an exclusion area for a $1000-\mathrm{MW}$ (e) nuclear power plant. At a fish yield of 10 tons/acre-year (a pessimistic value for irriensive culture), an annual production si $\mathbf{4 0 0 0}$ tons or $0.02 \mathrm{lb}$ of fish harvested per $1000 \mathrm{gal}$ of $\mathrm{H}_{2} \mathrm{O}$ could be realized. This is less ambitious than the production rate at Thousand Springs Trout Company in Buhl, Idaho, where $60.000 \mathrm{gp}::$ of water is distributed over 10 acres, and a harvest of 10r tons/acre-! ear or $0.06 \mathrm{lb}$ of fish harvested per $1000 \mathrm{gal}$ of $\mathrm{H}_{2} \mathrm{O}$ is schieved.

For a U.S. population of $\mathbf{2 0 0}$ million and a per capita fish consumption of $10 \mathrm{lb} /$ year, the national consumption of fish food would be 2000 million $\mathrm{lb} .^{43}$ If $10 \%$ of tinis fish consumption were supplied by thermal aquaculture, the equivalent of twenty-five $1000-\mathrm{HW}(\mathrm{e})$ power plant installations of the type postulated would be required. If per capita consumpition increased to that in Japan (100 lb/year), the number of $1000-\mathrm{MW}(\mathrm{e})$ power p'ant zquaculture i istallations needed would be 250. In terms of laind requirements, 10,000 to 100,000 acres would be used.

Table 13 gives some extrapolations for the years 1970 to 2000 based on similar assumptions as given above. The figures show a decrease in the fraciior. of heated effluent utilized from $14 \%$ in 1970 to $2 \%$ in 2000 . Changes in per capita colsumption or the fraction of demand furnished by thermal aquasulture could significantly change the figures. In any wase, only a snull fraction of the waste heat available from steam power plants is required for aquaculture, and though aquaculture employs the ambient temperature of the water. the heat is, of course, not consumed. The production of this ambieni temperature by other meaus, however,

Tabte 13. Thermal anpacalture bnd and waste hisent abjecteivn

\begin{tabular}{lccc} 
Year & $\begin{array}{c}\text { Population } \\
\text { (millions) }\end{array}$ & $\begin{array}{c}\text { Fraction of } \\
\text { heates effue, } \\
\text { for thermal } \\
\text { Aquaculture } \\
\text { (\%) }\end{array}$ & $\begin{array}{c}\text { Land for } \\
\text { thermal } \\
\text { aquaculture } \\
\text { (zcres) }\end{array}$ \\
\hline 1970 & 200 & 14 & 10,000 \\
1980 & 235 & 6.8 & 11,750 \\
1950 & 270 & 2.1 & 13,500 \\
2000 & 300 & 15.000 \\
\hline
\end{tabular}

'Roference: Naticnal Academy of Sciences, Resourcer and Man (1969).

${ }^{2}$ Market assumptions: (1) per capita consumption of fish foods, in Ib/year: (2) 10\% of demand furnished by thesmal equaculture. Changex in consumer lastes could change these ascumptions.

3 Assumes $20,000 \mathrm{lb}$ live product/acsi-;eas. viould recuire the expenditlice of very brge quantities of energy.

!t is, of sourse, extremely diffiult to predict a market for a new technology like thermai aquaculture, and a the cough market analysis is required. Further, the impact of thermal aquaculture on waste heat utilization should be considered on a site-by-site basis, becsuse water quality is highly variable and the ambient seasunal temperature of water used for cooling purposes is important. Conditions in one section of the country may not apply to other sections. Even within a region. the temperature and quality of waters are highly variable. If, for example, water temperatures are lower in the wintét than for the simplified case presented, then fish produciivily would be adversely affected. Therefore, generalized projections on a nationai basis can be very deceptive.

\section{Technological Problems and Development}

The utilization of waste heat for aquaculture will have little effect on the amount of thermal eneroy to be dissipated. However, the waste heat can $b$ : used to increase food production. In some instances, fish production would result in a raduction in discharge temperaiure, since ambient temperature water would be blended with the warm effhient to maintain the optimum temperature range for tish growti. Ir, this case the temperature of the return water stream wusld be reduces. Thermal plant cycle efficinacy sould oniy be af'ected if the winter discharge cooling water temperature were maintained above normal values.

Oniy once-through cooling has been studied to date. Aquiculture in conjunction with closed-cycle cooling towers has the advantage of higher available wate: temiperatures but would require a feasibility study, oecause tower blowdown rates (which would remove wastes) are at least 20 times less ihan for a oncethrough system. The effect of particulates and increased dissolved solids in the blowdown as well ais biocides added would have to be considered. Fish culture in the main recirculation stream could be a possibility, but fish wastes will have to be treated prior to recirculation to the power plant condenser. The adaptation would requirs further study.

Another possibility for using warm water from a cooling tower system is to circulate the water through a heat exchange system (such as that described earlier for geenhouss and animal shelters) to maintain the temprerature of a buildirg which houses aquaria or fish calture tanks. In this enclosed concept, ${ }^{44}$ aiready in the (mmonstration phase, large tanks are stacked vertically 
on frames. Each Iank contains sufficient water for $\mathbf{5 0 0}$ one-pound fish. The water is recirculsted ontinuously through the tanks to filters and aera:ors. The amount of heat required to mantain the buildin temperature inpends on the tuilding surface area, insulation and ciimate, but would be in the range 0.25 to $0.5 \mathrm{MH}$ pet acre of space used.

Large-scale use of waste heat for aquaculture would probably not be considered until demonstration projects at existing sites indicate an economic viability. The projects mentionad earlier may serve this purbosk.

Since the demonstration phase may occupy sever2 years. it is unlikely that larger freilitie. sill be planned soon for plants under construction or design. Although such facilities could be installed at a later time, it would be preferable to include the aquaculture facility in the original site selection and planning-

Engineering design and evaluation are needed for intensive aquaculiure sostems. Applied research and deveiopment woik would be neceseary to complement engineering tests. For a given species, mass culture techniques can be quite different from laboratoy experiments. Flow rates for channel culture must be optimized so that energy spent on physical activity is minimized and food energy conversion into flesh is maxinized. Aeration systems should be evaluated. Fish handling devices for transferrirg and harvesting in a flowific systerr need to be considered. Fish waste ireatment systems need to be designed and potentially represent a significant problem. For the near term. wastes might be diluted by installing relatively small aquaculture farms at each power station, thus holding waste concentrations low, consiatent with water quality standards. Low-cost nutritionally balanced feeds must be made available.

Selective brceding should be considered to produce species particularly amenable to intensive culture. Fish culturists must be able to fumish fingerlings the year-: ound in order to have iruly continuous culture. Medicinal treatment methods must be available to treat fich diseases rapidly, particularly in intensive culture. Water quality must be satisfactory.

Other technical and nontechnical problems may include the following:

1. To increase the reliability of heated dischary water, it may be necessary to practice ayuaculture at multiple-unit plants. Only a fraction of the tord volume of heated discharge water would be used for aquaculture, so that in the event of an outage, a switch could be made from a monoperating to an operating unit.
2. Even if multiple units are available, unprogrammed shutdowns could cut off the warm water upply suddenly. Such rapid temperature changes could be lethal. and. at least, fish growtis rates would be lower until the power plant resumed operation. Howrever, it might be necessary to provide for rapid valving to an alternite operating unî̀ or an auxiliary supply or :O stop the water inflow so that thermal shock is minimized as a resuit of the shutdown. Systems with large thermal inertia would be less affectid. Sudden temperature changes on startup could be ameliorated also by gratual blending of heated discharge water with recirculated ambient water.

3. Batch chlorination of coolant water say result in a residud free chlorine concentration that is toxic; this may be prevented by zeration to drive out the gas, by reverting to continuous chlorination instead of the conventional batch treatnent, or by substtuting mechanical cleaning devices ${ }^{4}$ or periodic thermal shock treatment of the cooling tubes of the condenset.

4. Increased copper concentrations occur in the dis charge water from power plants when condensing temperatures above $100^{\circ} \mathrm{F}$ are employed. Copper tends to concentrate in oysters and causes a green coloration. Copper may not be a problem if the condenser steam temperature is held below $100^{\circ} \mathrm{F}^{46}$

5. Nuclear plant thermal water used for aquaculture must be protec'ed from radioactivity being discharged into the stream. Monitoring of activity in the cooling water would certainly be required. Fossi-fired stations would of course not have this reguirement.

6. Fish wastes discharged from an intensive culture facility may have to b. semoved by acceptable waste treatment methods to minimize the BOD discharged to receiving waters and to meet water quality standards. The waste treatment plan'. size, design, and economics will have to be studied for each facility.

7. Lezal and regulatory restrictions such as whter quality, water rights, and prior appropriation (regulations on the total amount of water us ble in a power plant) may influence the vibbility of the idea in certain rejion, inchuding many western states 47

8. Repulatory restrictions on the diecharge of heated water may eliminate the once-turough approach that has treditionally been used in hatcheries. 
9. Insurance costs might have to be borne by a food cultivator to cover damages thai might result from a sudden accidental release of radioactivity or chemscals from a nuclear or fossil power plant - a statistically Iow possibility but a real one.

Varions iypes of integrated systems may be considered. Multispecies culture systems might be considered, inchuding finfiah in channels, comversion of fish wastes to algae, and intensive oyster culture fed on this aloee.

Agriculture-aquaculture systems might be considered, particularly in the summertime when themal effuent temperatures may be 100 warm for fish culture. Greenhouses might be used as cooling towers to extract heat froin thermal efluents, and the discharge from greenhouses may be used for fish culture. This integrated system might formit the maximum utilization of waste heat for food production, and simultainously incorporate aquaculture into a closed recirculating system instead of a once-through cooling system. However, fish waste treatment would be a necessary part of this system and may be expensive.

Demonstration of intensive culture using a culturable fish species and power plant thermal effluents is reeded, and information is needed on the degree to which yields are improved by waste heat utilization in small pilot systems. The facility at the Gallatin Steam Plant should answer some of these questions for that specific site and species; work now being carried out by Long Island Oyster Farms, Inc, at North,port, New York, will provide additional information on oysters, clams, and scallops; and work in Florida, California, and Maine should provide information on other species. Additional demonstrations at other sites for other species, however, are still needer. Once the data are obtained, sufficient information will be avallable to determine the incentives for performing the engineering, biology, and chemistry necessary for thermal aquaculture on a coinmercial scale.

\section{Summary}

Thermal aquaculture is a method for using heated effluents productively: but it does not necessarily reduce the heat disfosal problem of ine power plant. Basic data show that warm-water fich growth rates could be increased hy a factor of 2 to 3 by controlling the temperature of the water medium within the range $75-85^{\circ} \mathrm{F}$. Yield potential can be optimized in flowingaream aquaculture, employing nutritionally balanced feed and oxygenation of the water. Food comversion efficiency also improves with temperature control. With technical innovations, a significant reduction in production cost comparable to that already achieved in the chicken broiler industry could occur. Seafood consumed in this country is largely wild stock, and comparatively little effoit has been. expended is culture fish on an intensive basis as is done with lami animak.

Waste heat is sanlikely to be used in Iarge-scale applications until succesuful demonstrations have ber achieved. Therafore, the short-term impact of this extivity on power plant siting should be small. Over the longer term, however, the posibilities for aquaculture should be considered during site selection. Site-riented demonstration proprums are needed to provide the technical data that will indicate the exient of improvement in quality and yield of culturable foth species through greater environmeatal control. These demonstrition programs, some already in progress, will show t'ae viability of thermal aquaculture.

Thermal aquaculture will not dininish the amount of waste heat to be rejected from a power plam. During the summer, to mintain optimum growth temperetures, it may be desinble or necusary to ditute the heated dichnge water with ambient temperature water. To the extent that ambient temperature water for blending pupoes is avat-ble, this dilution process will reduce the temperature of the water dicchangal to the receiving water body. The cost of this dintion would be borne by the aquacultare operatur and the power producer. During the vimter, aubient temperatures may not be as wam as deaired, and this will reduce growth.

Unles it is removed from the culture stream efficent, fish waste could contribute to the pollonion of the receiving water by increasing the biolojical ixycen demand. The cost of adding a treatment plant to take care of fich wastes, particularty in the efinent of an interivive culture facility, should be concidered and svluated as part of the economics of thermal aqua. culture.

Lezl and regulatory problems enecuntered in implo menting thermal aquaculture will be discased in the next section. These problems need to be resolved before commercial thermal aquaculture will become a reality.

\section{References}

1. C. F. Hickling, Fish Culnure, Faber and Faber, London, 1962.

2. S. L. Hora and T. V. R. Pillay, Hondbook on Fith Culnure in the Indo-fuctic Resion, FAO Finteries Biolosy Technical Paper No. 14, Ficheries Div., Bioloy Branch, FAO, Rome (February 1962). 
3. J. H. Ryther add J. E. Bardach, The Seanes and Potential of Aqumulturi. Articularty Imertebrate and Algae Culture. prepared for the National Council on Marine Resources and Engineerizg Developmem PB 177767 (Clearing House Fed. Sci Tech. Info., Sprinefiedd, Va., May 1968).

4. J. E. Bundach and J. H. Ryther. The Suans and

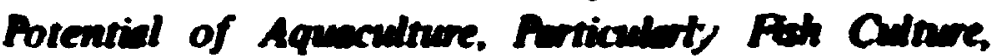
prepared for the Nationrai Councis on Marine Resources and Engineering Detelopment PB 177768 (Clearing House Fed. Sci. Tect. Info., Springfiedd, Va., May 1968).

5. K. Kuromima, New Sysrems ad New Fishes for Oinure in the EAt, NM 45116, FR: VIII - N/R-I, WSWWFEC, FAO, Rome (1966).

6. G. Miburn, "Catfish Farming, It Hes Poteatial. Profits, Problems," Netional Fithermen SA(B), IC November 1969).

7. "Word's Linged Trout Farm." The Amerion Fin Former 1(1), 6 (Decenber 1969).

8. J. H. Ryther, Woods Hole Oceanographic Inat

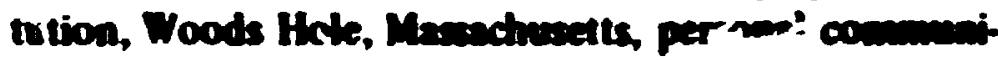
stion, April 1968.

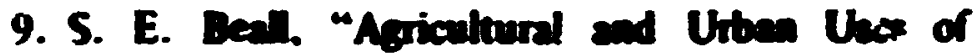
Lom-Tesuperitus Heat," Procectims of the Confers.

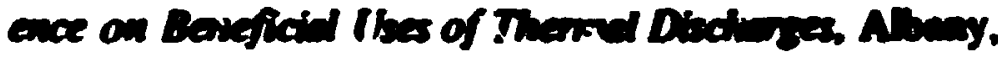
N.Y., Sepresaber 16-18, 19 ĩ.

IU. Z. P. Zeinetlin and D. Z. Aldrich, "Gromth

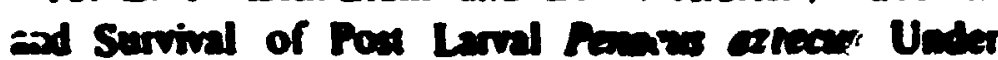
Controlled Conditions of Temperatese end Salinity." Bol. Bul. 129, 199 (1965).

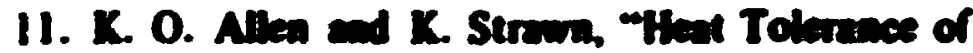

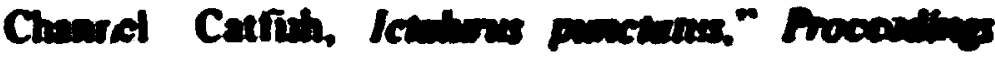
of the 21st Alunal Conference of the Souminad

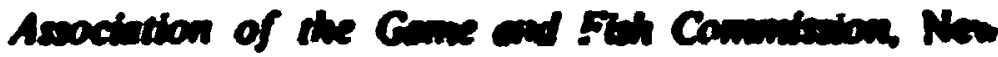
Orleaver Le. Seph. 24-27, 1967. pp. 399-4ll (1963).

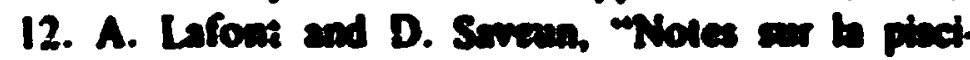

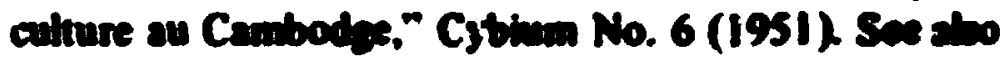

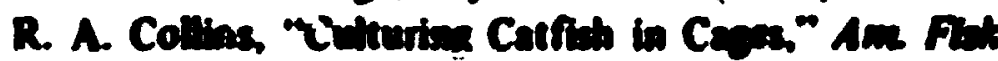
Former 1(3). 5 fFobreary 1970 .

13. R. E. Berroms and B. D. Contes "Comprind

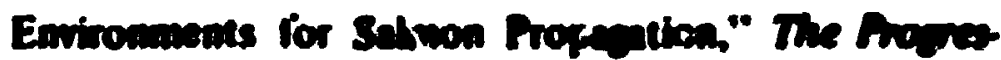

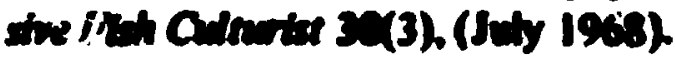

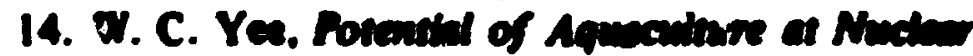

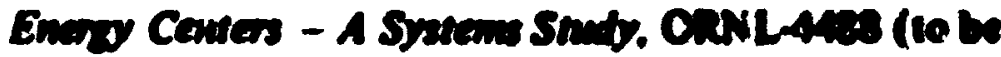
polinedud).

15. Ceat Modowell (TVA) to Dary Nichots (OANL). Jan. 4. 1972.

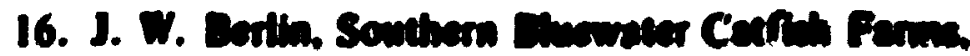

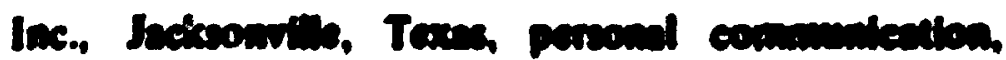
Mareh 1969.

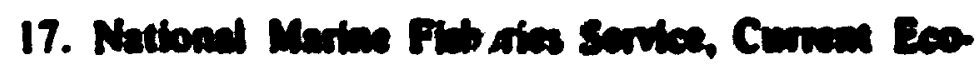

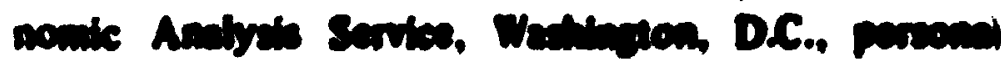

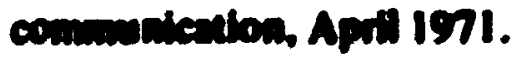

18. B. E. Hefferma, "Confucion in the Market Phace." Fich Foming Imdutries 211), 5 (Jamary 1971). Abo J. W. Ayres and M. Martia. "The Catfich Market: Problems and Promise." Am Fah Fonmer 244\% 10 (March 1971).

19. D. Timmons, "Oyster Cuhture Heralts lenocui's More into Aquafoods." Fas Forming Industries 2)(2),8 (April 1971)

20. J. E. Tition and J. F. Kelley, "Exprimental Cave

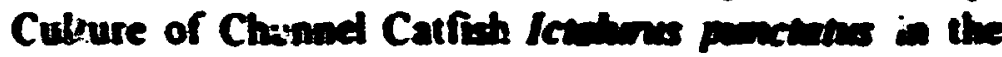
Heated Diacharge Water of the Moreen Crect Stem Electric Geserzing Station, Late Colordo Ciny.

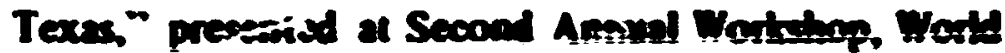
Marioulture Society. Beton Rowe, Louining (Feb. 9. 1970).

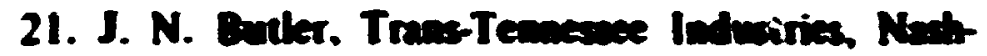
ville. Tean. persosed communication, April 1971.

22. Press Release by Flotida Power Corporation, St. Petentere. Flocita, March 12, 1971.

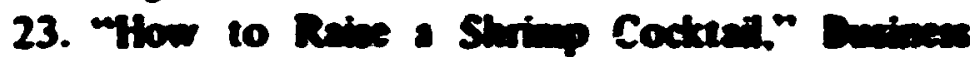
Weat No. 2090. 184 (Sop. 20, 1969).

24. R. F. Coysor, Prative Ges and Enetric Company.

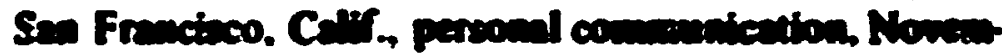
ber 1970.

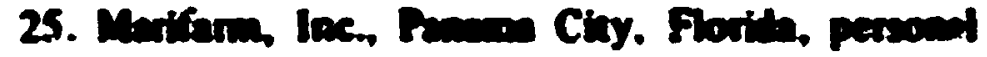

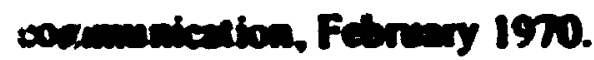

26. C. B. Kender. The Poremith of Leverer Cot tere," The Am Fu Fumer I(11), 8 (1970).

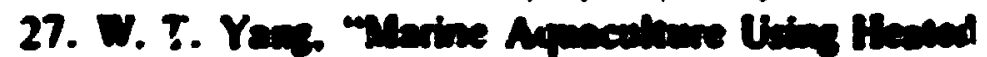

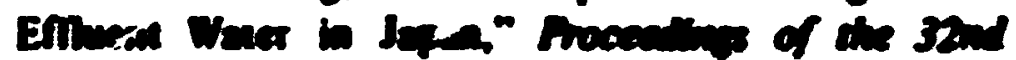

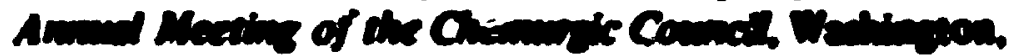

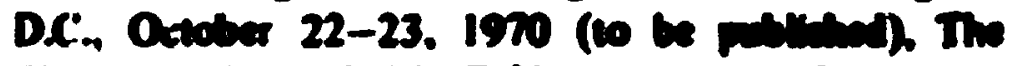

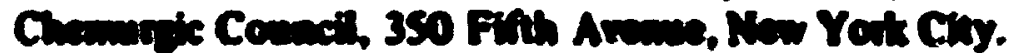

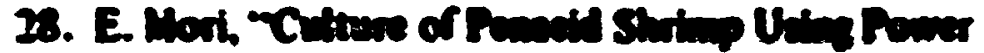

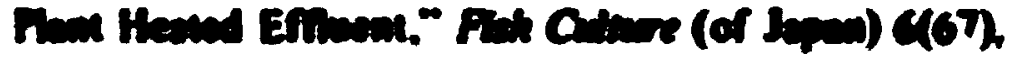
$113-15$ (1969).

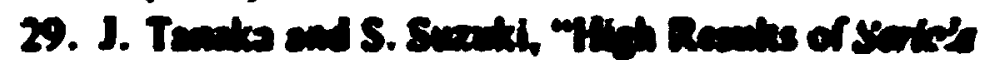

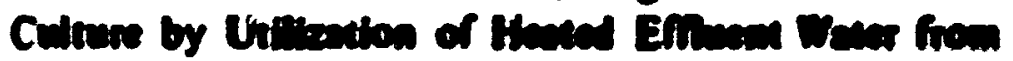

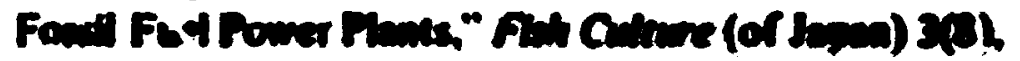
$13-16$ (1905).

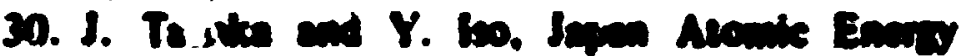

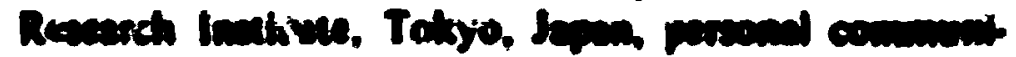
ention, Mareh ISTI.

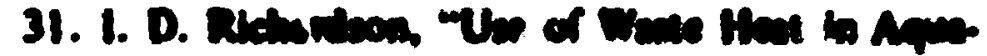

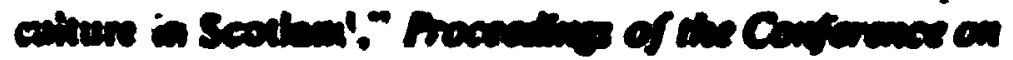

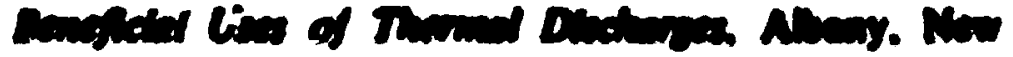
Yotr. Eax. 16-13, 1970.

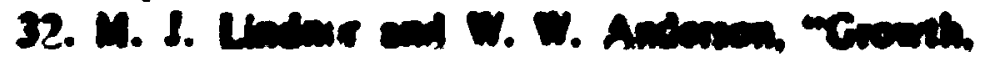

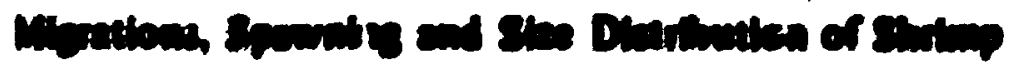

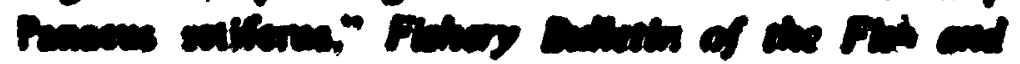

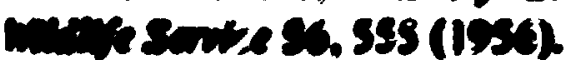

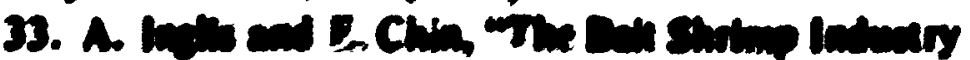

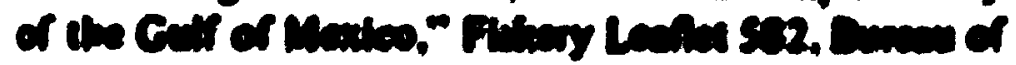

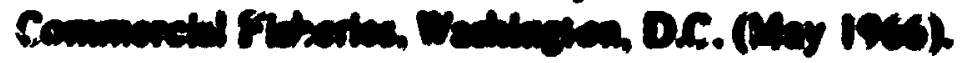


34. "Japra uni the Sea Exchange Rate: 70 los of Shrien fe 1 to of Gold." Ocem Inctustiny 4(12), 49 (Daceniber 1969).

35. W. T. Vlas. University of Miami, Mirmi, Florida. persomal communication with T. Harada of Kinkj University, Japan. November 1970.

36. Richard C. Alchison. "Seafood !farketing and Economics." in Proceetings of the Nationvl Conference an Wase Hat Uritizarion. Gatlinburg. Tennessee. October 27-29. 1971. CONF-711031.

37. Fidheries of the United States. 1970. Current Fidvery Stationics No. 5600 . Notural Marine Fisheries Service, Wedrimpion. D C. (March 1971).

38. Shellfat Sinusion and Outbot 1970 1mmed Revien, Curreat Ecosomenc Aalysis S-20. March 1971. Divition of Currex Economics Amabysis, National Mariene Fisheries Service. Westington. D.C.

39. Food Consumpoion Prices and Expendinures. Agricultural Economic Report No. 138 and is Sypple. nem !si is59. Esomomic Revearch Service. U.S. Dept. of Apriculture, Wedingen, DC.

40. D. P. Cleary. Wortd Dewand for Shrimep and Nuswas May Outurip Suppty Durieg Next Decade." Comsoncied Finteries Review 3243), 19 (March 1970).

41. F. T. Chriaty and A. Seott. The Common wheinh

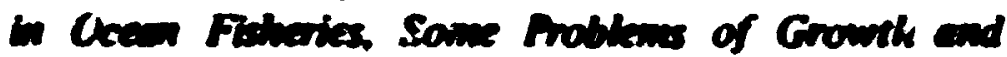

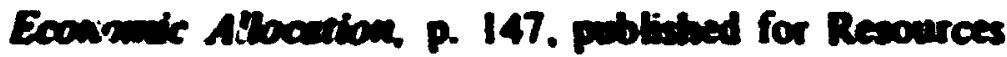

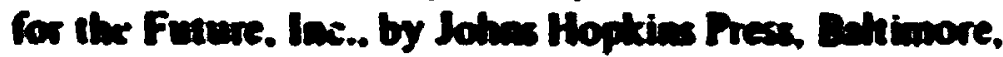
Mangiond (1955).

42. A. Cortent. "A Look at the Fretworater Fin

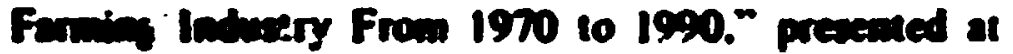
The Wration Conference on Deaneficial Uses of Wade

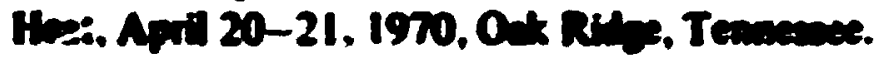

43. Resources an Mine Motional Acadesny of Scleace. probistred by W. H. Freeman and Company. Sen Frnocicoo, Culr. (1969).

44. Yrastlond Production Posible What Imeswive

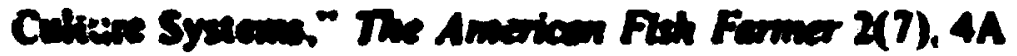
(bune 1971).

45. Menofactered by Amertap Corporation. Loa Vend, Ning Yout.

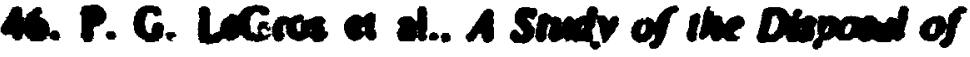

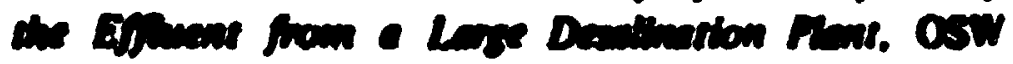

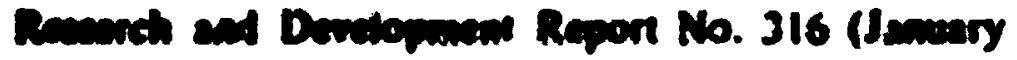
rish.

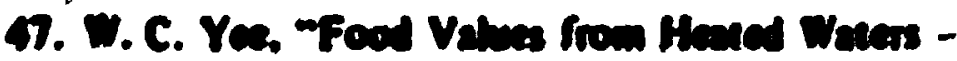

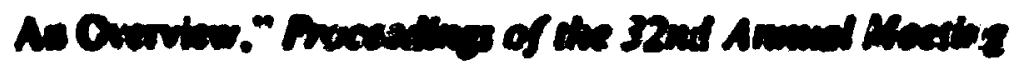

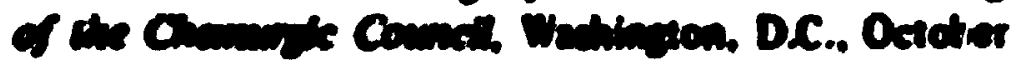

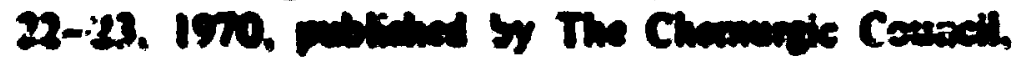

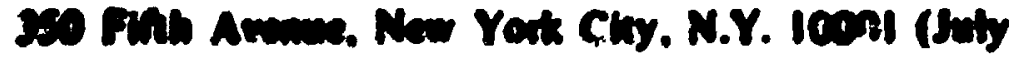
isti).

\section{CONSIDERATIONS WN MPLEMENTING WASTE hEAT USE}

A review of the utilizatice! of was! 2 heat would hardly be complete if only techurical aspects were considered. It is clea from an iraminaion of waste heat use that many difficulies are associa:ed with implementing the technislogy which already exists. The mismatch between the avaiblble heat and the needs for various potential applications, the traditional role of utilities as suppliers of electricity and the impact on this role of supplying waste heat, the arrangements required toween entreprenews interested in using heat and utilities inte exped in sipplying heat; all ate importsat considerations. Similarly, the influence on rate structures for a highly regulated industry and the impact of increasinghy restrictive environmental standards are additional important concerns.

The problems in implementing waste heat use were considered sufficiemtly important and sufficiently diverse that they served as the subject of a major portion of a National Conference on Waste Heat Untivention sponsored by the Electric Power Council on the Environment and held in October 1971.' The Confereace explored many of the nontechnical impediments to heat utilization, and much of the matirial in thus section is drown from information presented at that mettine.

\section{Mracking Denand with Sexpity}

Moder, sean power plant generating cipacities are bure ond thus make bare amounts of wiste heat ancisole at the power plant. For example, a 1000-MW electric poiver plant produces approximately i $\times 10^{13}$ Bu/lyear of waste ical, and since the projected uses for beat are often not enengy intenaive, isteraive faciltives would be required to we amounts of heat comparable to that anilable from such large plants. Agricultural or aquacultural fecilitios for uning all this heat would requibe an investment of many millions of dollars. Facilitios capoble of using large amounts of heat may in turn be poorty nusched to the market potential for the products producad. (The potential for production of cricolleural and squaculuural products as indicated cadien in this report can be a sipnificant frection of the cotal protuction from exiation facilities in this coundery.)

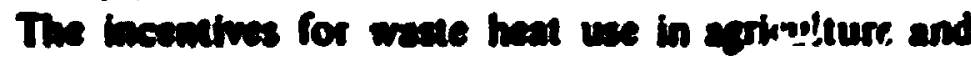

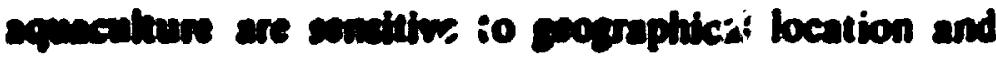

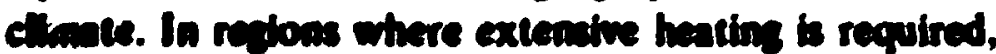


heating costs may inake the avaibability of large quantities of low-cost waste heat an attractive incentive. In warmer climates where heating cosis are substantially less, the incentive for waste heat use is correspondingly raduced. In any case, the fraction of heat that can he realistically used when compared with the amount of heat nationally available is likely to be sum:".

An attractive alternative for heat utilization not explored in this report may exist through the coupling of smaller heat emission sources from industrial or other activi...s with heat uses described here. Waste hea:, for example, from a 5 - or 10-MF̈ self-contained gene:ating facility or from an industrial waste heat so'stc: might prove to more closely match the quantity reauired by potential heat uses and may allow production to be more compatible with surrounding area markets. However ise of even a fraction of the waste heat from a gerierating plant improves snergy utilization and may surplant energy sources which would otherwise be needed for the application. A matching of waste heat use tc waste heat available is not a requisite for heat utilization.

The use of waste heat will not alleviate problems of thermal pollution except in specific cases. For example, in aquaculture, actual temperature degradations which occur during the utilization process are slight. Similarly, the substitution of greenhouses for regular : sulen towers may result in relatively little difference of impact on the environment from the discharge of heat. Such an energy use, however, may substitute for another energ:- source which wou'd otherwise be required and thereby would eliminate poilution from that source.

At present, \& large mismatch exists between the amount of heat available from steam power plants currently jeing constructed versus the reasonable quantity of waste heat that might be used at a given site. This mismatch may not impose any penalty on the potential user, but the ability of the utility to rarket only a small fraction of the heat produced may reduce the incentive for utility participation.

\section{Coraidentions in the Marketing of Heat}

Few steam electric power plants in this country market heat as a second product of their electrical power production. Yet the extensive use of waste heat from power plants will require the consideration of the seam power plants as a multienergy source producing both heat and electrical energ,. Such a multienergy role for utilities, however, may initially generate problems as well as energy.
There are encumbrances to utility efforts at do veloping markets for waste hat, and these include a utility concern fo: the infuence oi profits from beat siles on the rate structures for electrical eavery. This influence may be a function of the degree of sacoes exhibited by the utility in marketing their waste beat product. Utilities question how their research expenditures for developing methods and applicaticas for beat utilization will be : eated in setting the rate structure cn electrizal energy sulex. Unless opportunities exint for the utility to increase profits, there wil be a reduced incentive for the utility to invextigate means for heat utilization. Rate requlatory podis provide couragement to utilities to develop systems which we waste heat in order to keep prices of electricity down. There is evidence that this is occurring." The initintion of efforts for waste heat applications by poteatiol extrepreneurs may provide one pathway and an incentive for stimulating invastigative progroms on hen utilization, but the success of such projext? will reypire efforts by both the potential supplier and potential ber of heat.

Under nonmal sontract practice, utilities awoid responsibility ior censumer loseas because of bos of electrical power during unsthedulad outres of the utility. It is almosi certain that utilities would be beth to enter into agreemenis for supplying beat where bow of heat migint reflect as a responibility on the wity. Utilities are likely to seck agreements which prechide responsibility from power outages or which anoid increased restrictions on utibity operations to better accommodate the entreprenee: in his utilization of waste heat. ${ }^{2}$

The extent to which 2 utility may modify operations to accommodate the iequirements of the waste beat user, and indeed tire operating relationship between the user and supplier of waste heat, must be carefully worked out. An example of a cooperative effort on waste heat utilization is illustrated by the sereesceat between the Rabston Purima Company and the Floride Power Corporation to conduct a mariculture research program and a commercial operation at the Crystal River site of the Florida Power Corporation. In their agreement, Florida Power and Purina are sharing fimacial responsibility for research efforts necearany to the develonment of the commercial exierprive. Raltion Trurina has almost total responsibility for securing the neceseary local, state, and federal permits requined for the proposed activities. Both Florida Power and Purim conducted extensive discussions with the sate and federal authorities in their initial inveationtions of the feasibility of the project. Their sreement defines the 
exteat of libbility for each of the corporations in the enterprise. Florida Power will not be reguired to modify normal operation of the power plant for the production of electrical power in onder to satisfy the meads for the aquaculture facility. The aquaculture faciliny will have to adapt to the requirements of the power generating station.

In order to enaure an active interest in the success of the venture, both corporations are investing in the research and construction program. The care and time dewied to renching the agreement between the parties inmoived reflect the importance attached is both nembers of the areement to the need for a clear definition of their retative posinions. ${ }^{3}$ The Florith Power-Purien venture, however, represents just one form of many types of arrangements that may be inplemented.

Numerous queations have arisen on the role of the utility as a matketer of heat versus its traditional ioik as 2 regaloted marteter of electricity. The attitude that regabtory aeacies will adopt on the regubtions required and the restrictions on utility operations is not chear. The regulation of the utility many stoangly depend on the application and the customer. $A$ utility dealing with an inoividual customer (es., a greenhoure operz. tor) mingte be free of regulations, while a uttity marteting wate beat to a city or urban development nay be under cloce regabation.

The inflesce of income from the sale of heat on the sue zecture for the utility in the sale of electrivity way be an imave of inaportance. The incentive for the utily in pursuing the morteting of waste heat may be strongly iniluenced by the regulator; decisions on such waves. Revesues, for example, from the sale of waste beat to a private entrepreneur might be credited against the con of producing electrical power in much the same way that the jale of fly ah is credited against the cost of ach removal systerns. ${ }^{5}$ On the other hand, positive surias may occur through a reduction of heat dissipa. tion equipment required by the utility, by marke:ing the heat to an entrepreseur who will return cosled water to the utility. The utility may therefore bxe an incentive to market the heat at very low coet or pertaps on a free basis in order to save capital equipoment coets. Cosceivibly, the utility itself mignt even pay certain coets to supply the heat to an entrepreneur, and in this cose, such costs could be credited apinat the cout of service in cetermining the rate structure."

If the utility itcelf enters into a business, using wate hoot, then conts ancociated with the enterprize, whether aies or lowes, would be chapeble to the emerprive and nhimately to the stuck holders."
Few precondents exist which 'ypify the retative retstionship between tive uitity and the user and which give information on whai the sffect on rate stnecture might be. But as morr arrangements such as the Florida Power Crystal River Proyect. the Long Istand Lightias Company and Long Isand Oyster Farms effort. and the TVA-Gallatin Steam thant work come imo beine. precedenis will be established on which additional enterprises might base their own arrangements.3.t.7 Generally, sate utility commiscions are responsible for setting rate strurtures, and the specific apreemeats reached by the utility on heat utilization will stinaty influence how the individual state commissions ireat tine coss and reverave; sacociated with the project." A high degree of varisbility may be expected in the various states.

\section{Lepl and Requbtery Problen}

Fundamental problems relating to the right to we water as well as the right to increase the temperature of the water mast be sotvied in onder to facilitate the productive use of water. Legal problems of water righis vary with the areas of the country under consideri tion. In the exsern states water rights follow the riparian doctrise, with or without regulation, while the western states suberibe to the appropriation doctrine (Colorado Doctrine) or 10 a combination of the riparien doctrine and the appropriation doctrine (Califormin Doctrine)."

According to the riparian doctrine the owners of lands bordering upon a stream have a riatht to the reasonable use of the natural flow of the stream past their land, with the water undiminished in quantity and unimpaired in quality." Therefore. diversion of water for open-field agriculture. Or the use of water for aqueculture without the treatment of wastes, may represent uses of waste heat that present water rights problems if practiced in riparian states.

Where appropriation of water is practiced, the problem may be less serious, since the right to the water could be purchased to provide the necessary amount of water for utilization of waste heat in aquaculture or open-field agriculture.' In the case of aquaculiure, however, other restrictions such as those imposed by water quality standards would determine the requircments to be met before disaharging the water back into the stream.

Increadingly stringent water quality standards may influence wase heat utilization. Limitations on the allowable diecharge temperature into receiving water bodies permit only a small temperature increase sbove ambient water temperature." ' In estuaries and coand 
waters. For exi wiple. allownble dixcharge water tempere ture increases sbove anbiem rane from 1.5 to $4^{\circ} \mathrm{F}$. depending on the tive of year. Such biscilations can

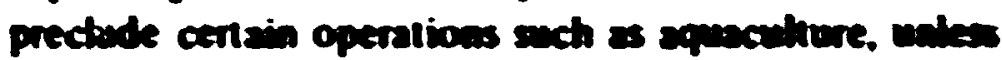

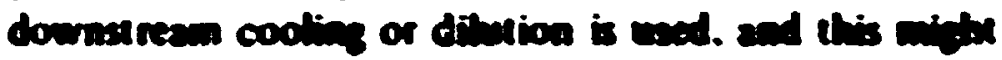

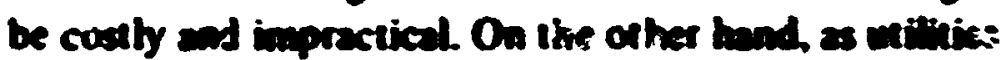
are forced to cooling tower indalbatoms ine bigher and

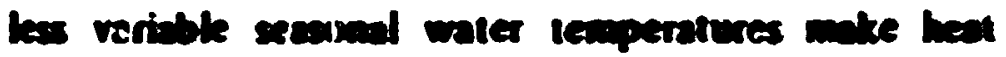
eppliedions more attractive.

Under present regalwajons the we of warm woter frum

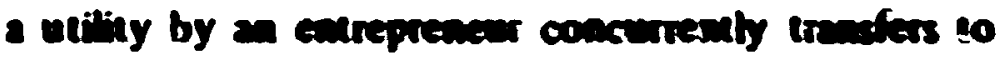
the entrepreacer the respomibeity for meetion water qualidy standerts. The posibiting of parforming a

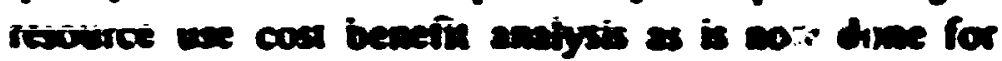

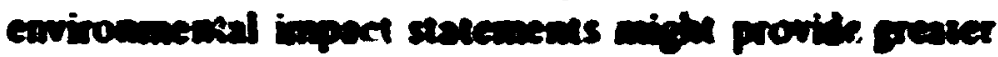

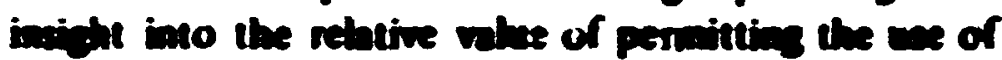

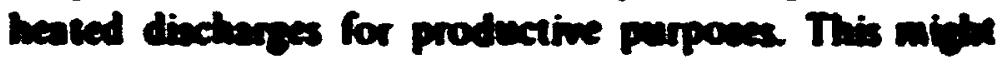
be devebped, for example, if the bees resource nes were

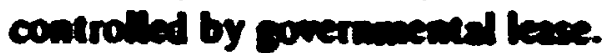

Legal questions exiat cosacenting the ommenthip of healed water dixthored from stem power phats. Such questions require resolution, bue andwers may be bidely

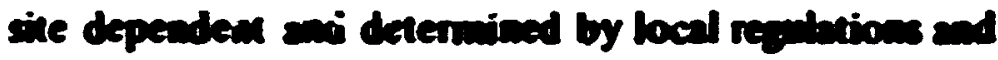

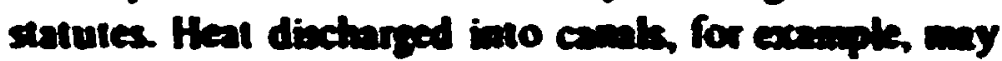
belong to the utility, white heat dischersed dinectly to a peblic streana may not.

The problews now focing Lom babad Oyster Farns and the Loag Istand Lithing Company are indicative of the kind of difficahies that un $v$ fece companies whathing to use the hesied eflocens from power phats 6.12 in the case of Long latand Oyster Farms, which has been wing the beated sffluente of the Long labad Linting Cc.ripany's Liorthpon Sieam Electric Generating Plant. the new restrictions imposed by the New York State Water Quality Standands may threaten the vidbility of the project and prevent its contisuation.

When the project was began by Loag Island Oyster Farms in 1967, the temperature linits for the Northport Plant restricted the maximum temperature of water discharged to Long Idand Sound $1090^{\circ} \mathrm{F}$. Since this maximum was near the optimum for the growth of young oysuen, the use of the heated water by Lons Island Oyster Farms allowed them to accelerate the growth of oysters, allowing harvesting in 2.5 years instead of the normal 4 years. By providing more iavorable temperature conditions during the .1 to 6 momths that would otherwise be loc cold for growth. the heated effluent is productivety used.

In September 1970, however, the state of New York notified Long laband Lighting Company that when Long Isiand's Unit 3 went on line at the Northport Plant, the discharge from the entire plant would have to comply

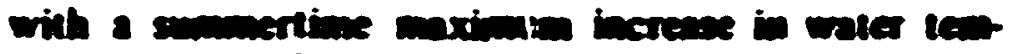

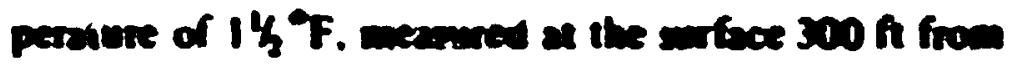

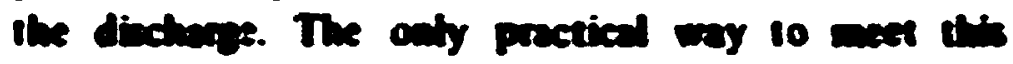

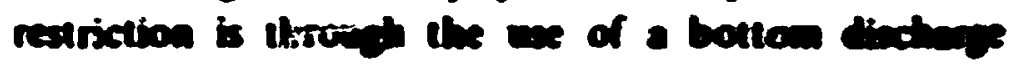

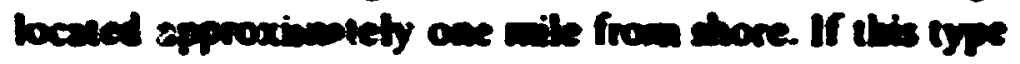

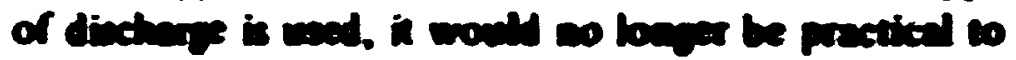

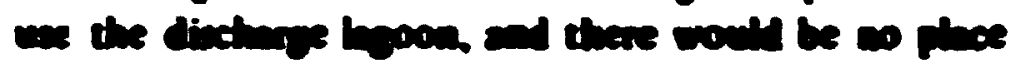

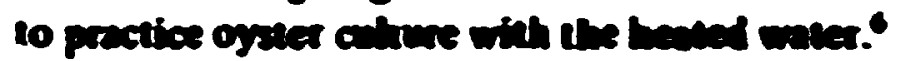

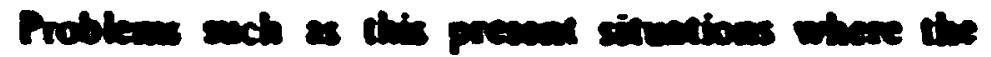

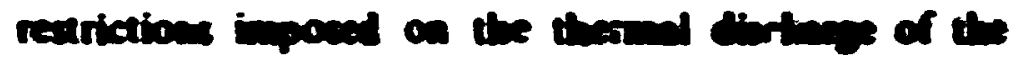

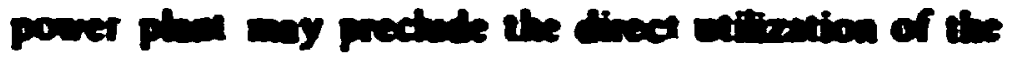

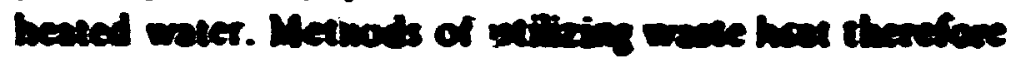

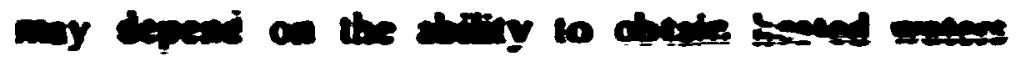

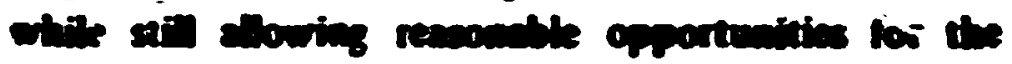

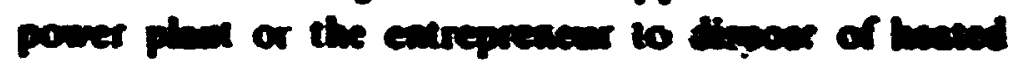

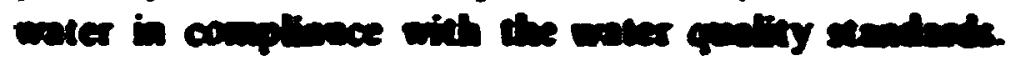

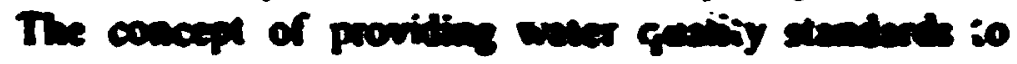

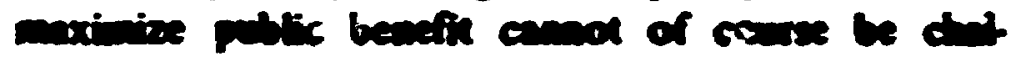

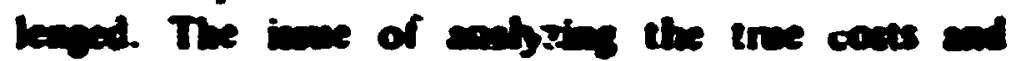

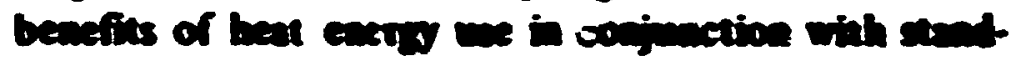

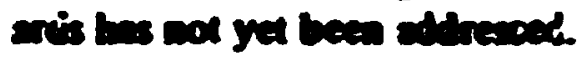

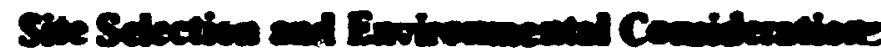

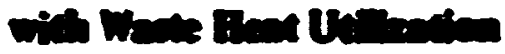

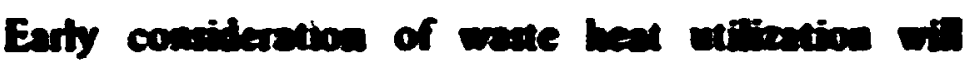

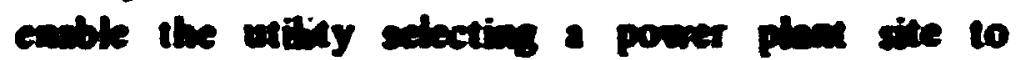

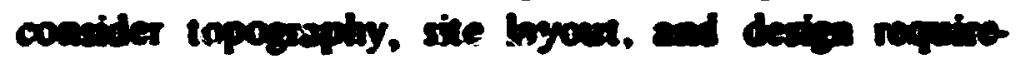

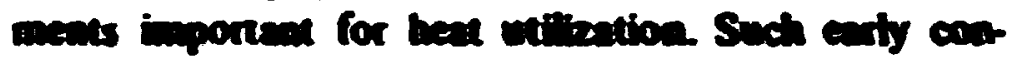
sideration ma facisiate the sebetion of a she comparible with a we of wave beos. 13

The applicability of differim beat wes wit be whe

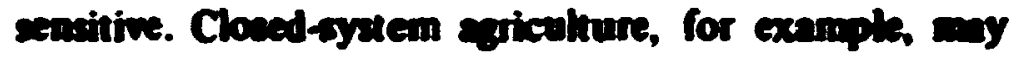
require extenaive had aress surrounding the power phent wish retatively level lopography, while the we of heated weter for openfield apiculaure requines not only suitsble terrain for waler diaribution, bet a sice where exinting water bu will wor prohbit such we. Ifigh cossomptive water we may be in conflect wh weter rights for many siten unlese such riftets esilet or are procured.9.10 In rejions whore weter is stort, conoumptive ua may be an unseceptisble inpact. If both heat and water are utilinad at a level which resulted in no additional problem from consumpotive wee, then the exvironments! inpact of the power pleat supplying heat might be leasened by the utilization of that heat.

In using waste heat to heat and cool gresabousas, benefits scenve to the utilization of wate heat beceume it is powible to coos water from the power phat while conserving weter. "4 Therefore, the inpact of relociting heat to the environoment is lesoned while water is 


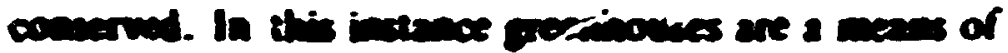

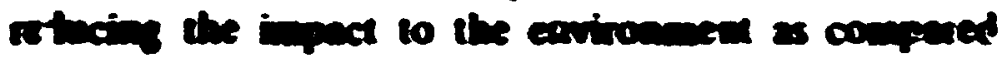

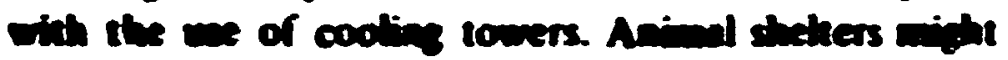
we the saser approuch as greentomes.

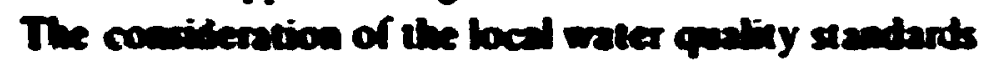
armiveste to the receiving water bolies my do

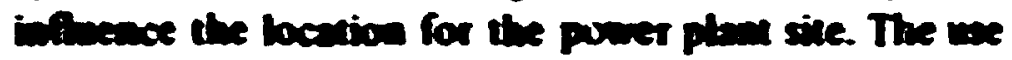

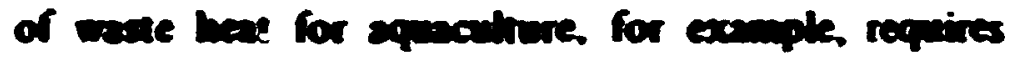

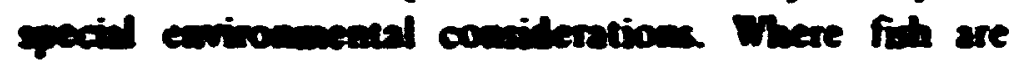

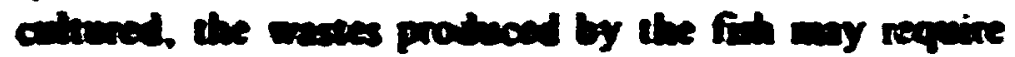

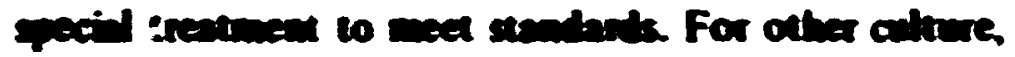

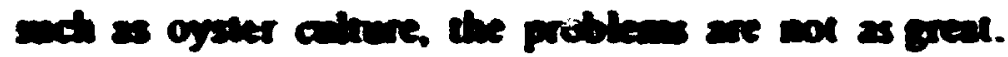

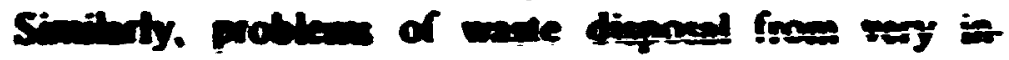

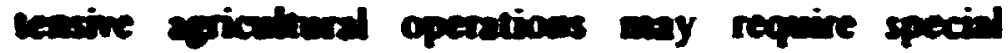
treabeat phats in onder to weet water quality or other

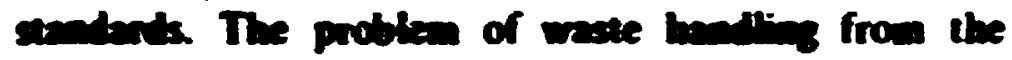

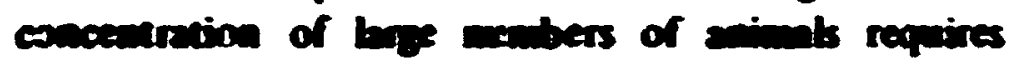

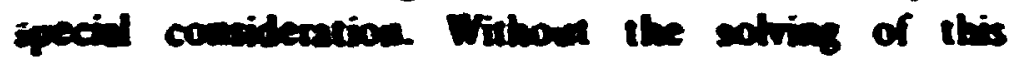

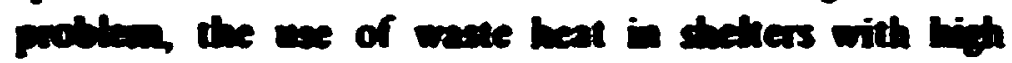

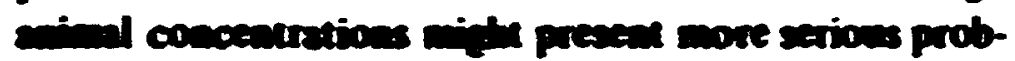

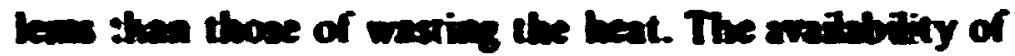

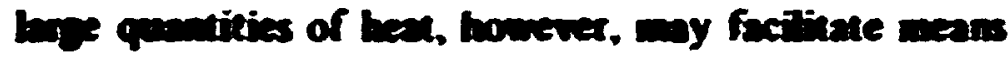
for treating aniond wedtes at sect indallations.

it is in the anture of the noc operations that imalusive

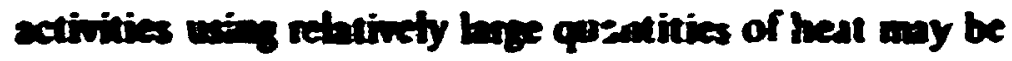

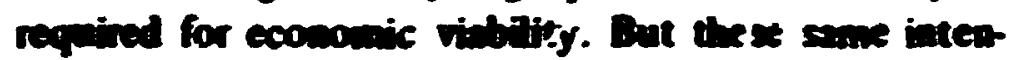
sive ectivitios wry create a hish potential source for polbetion. For each cane whece the vritiontion of waste bea is enticipated, there will be a meed to evaluate the

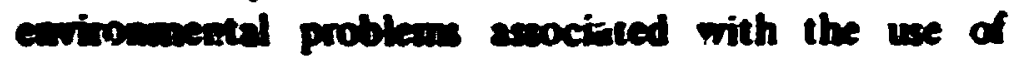
wase beat at that bocation to determine whether the cotal bewefits of uaing the waste heat exceed the total conts.

Health and safety considera:ions will arise particularty with respect to products using the effluent from nuclear prover plants. For example, it is proposed that cooling water circulated through the condensers of a muclear power plant be pumped through evaporative cooling puds in greeshouses located in the exshusion area of the medear plent. There must be accurance that products will be free of any radionctive contamination from the power plant. Monitoring systems may be required to exure that safety considerations are adequately met. Quntions of public aftitude on plant and animal products produced in facilities adjacent to power plants will arive. Dexions and operation for such systems will nave to inchude procedures to be followed in the event of comtamination of the cooling water.

2ncane of the costs of diatribution systems and the fect the the temperature of waste heat is already low $\left(\sim 100^{\circ} \mathrm{F}\right)$, heat must be used as near the heat source as pouste. The importance of plant site location for

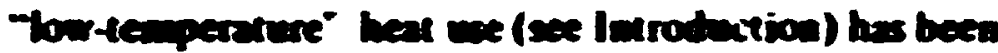

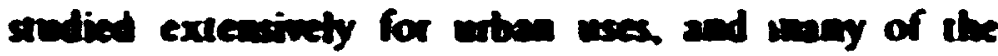
pore comiderations are spipticable for wase tempera-

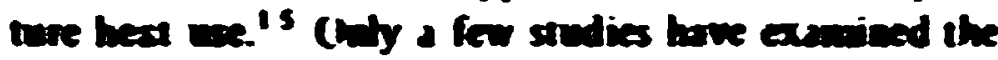
problezw with exeraine heat we fecitities iocated at itre power phen sice."

It is proitle that the aldiniond reqpirements in

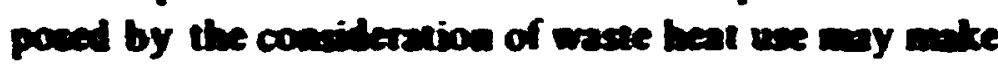
the sice sebective procese even wore difficul. For exmple. the alditiond conileration to becse sites

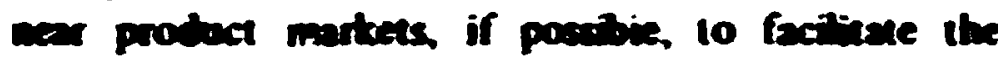

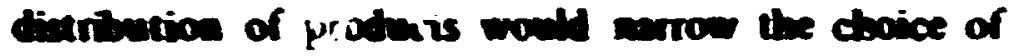

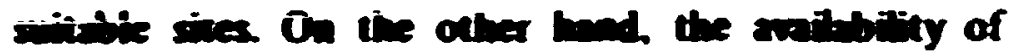
bre qumitios of bourente beat my provite an incestive for loceting a power phex in certain areas. It

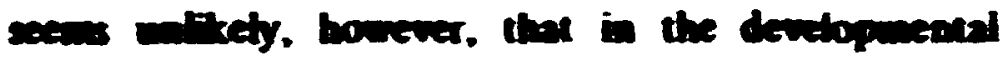

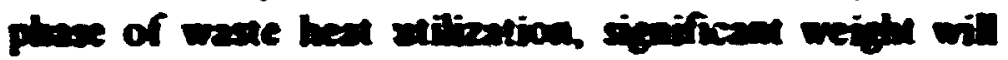
be given to heat cilingtion in the bection of a power

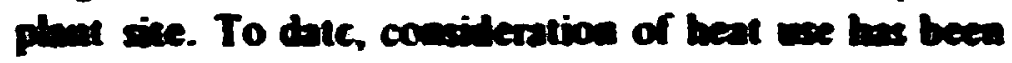

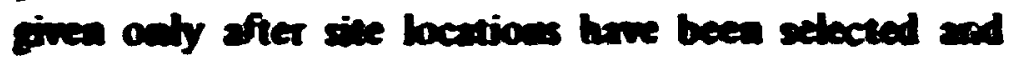
often after actual construction of phats are under way.

Over the longer term in is itety that effective wee of wate hea from poser phats will require carefin: atrenced planaing during the sine selation prosear. with parivenation of both the tritity and the waste heat wer, so that locations optimesn for both electrical production and heat emergy use are sebected.

\section{References}

1. Amceudiogs of the Nationd Conference on Weste Heat Uritization, Gatlinburg, Temessec, October 27-29, 1971, CONF-71 1031.

2. B. L. Price, "Thermal Water Demonstration Project," in Proceedings of the National Conference on Waste Heat Utilization, Gatlinburg. Tennessee, October 27-29, 1971 , CONF-711031.

3. W. R. Watts, "Marine Aquaculture at Crystal River Florida," in Proceedings of the National Conference on Whste Heat Utilizatiom, Gatlinburg. Tennessee, October 27-29, 1971, CONF-71 1031.

4. D. S. Smith, "A Regulatory View from the State," in Proceedings of the National Conference on Weste Heat Utilization. Gatlinburg, Tennesser, Octobe27-29, 1971, CONF-711031.

5. W. W. Lindsay, "Heat Utilization and Rate Structures," in Proceedings of the National Conference on Whaste Heat Utilization, Gatlinburg. Tennessee, October 27-29, 1971 , CONF-71 1031.

6. H. M. Doebler, "The Agencies and Thermal Discharges," in Proceeding of the National Conference on Weste Har Urilizetiun, Gatlinburg. Tennessee, October 27-29, 1971, CONF-71103!. 
7. G. G. Willians -TVA Programs - Waste Heat Vititization in Grecubouses and Othet Agriculturally Retaled Propects" in Mocedines of the Nerionel Corifenence on Ware Heal Uritionion. Gatimburg. Tenaessee. October 27 29. 1971. CONF-711031.

8. F. J. Trekase. H. S. Acomenthal. and J. R. Geraud. Coses and Mareriets on Nonod Resources. West Publishiog Company. St. Poul, Mina. 1965.

9. F. E. Msboney. -Leged Ruls: Gowerning Comsusp-

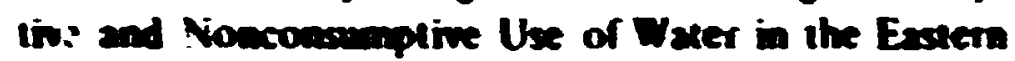
US: Rebtiondhip to Wrer Pollution Inctudios: Ther:ol Pollution: State and Federal Comenon Lu and Statutory Compot: Sen Wner: Aquatudure and the

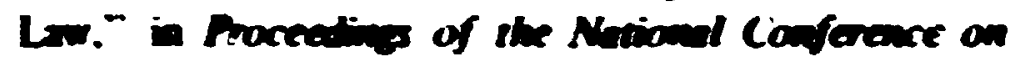

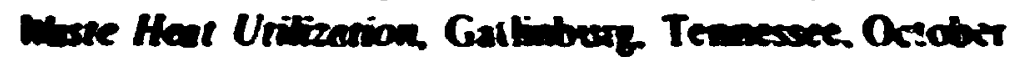
27-29. 1971. CONF-71 1031.

10. R. J. Hoses Tequ Probless in Wase Hea Uritiontion in Appropriation States" in Moceching of

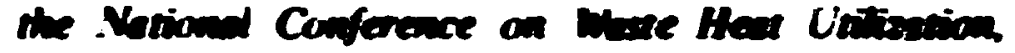
Getionbung. Tensessece, Ortober 27-29, 1971, CONF711031 .

11. R. H. Bryan B. L. Nichoth and J. N. Ranacy. "Sumary of Lexidative and Regubtory Activities
Affecting the Enviromenes 1 Qualiny of Neclear Faciinx- Vurder Safery 12461. 665-78 NovercberDecember 19711.

12. G. H. Vanderborth Jr.. "Thermal Enrichanea Problems and Potemial." in Mraceetings of ithe Notiond

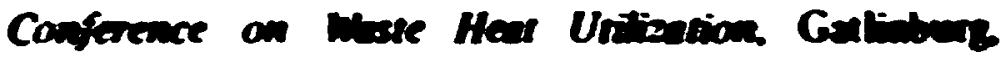
Tennessee. October 27-29, 1971, CORfF-711031.

13. M. M. Yaroch Tower Fina Siting and the Ube of

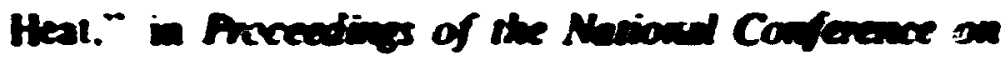

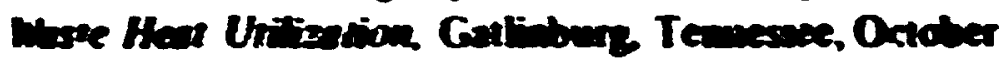
27-29. 1971 . CONF-71 1031.

14. M. H. leween "The Use of Whate theat in

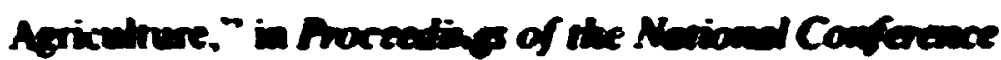

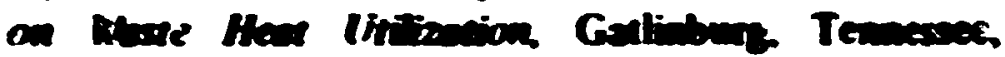
October 27-29. 15 i. CONAf-?I 1031.

15. A. J. Miller et al. Use of Sremendectic Rowor

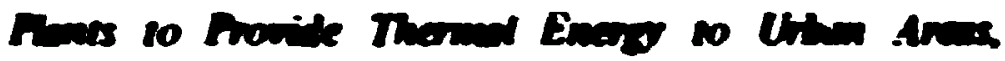
OnNL tWDA-14 (1971)

16. S. E. Deall and G. Samets The lise of win

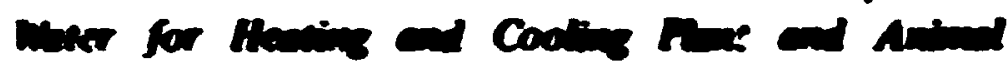

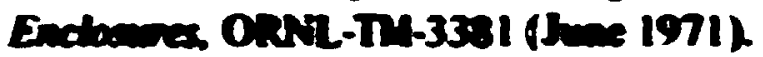

